\title{
Identification of Proteins for Salt Tolerance Using a Comparative Proteomics Analysis of Tomato Accessions with Contrasting Salt Tolerance
}

\author{
Peter Nveawiah-Yoho, Jing Zhou, Marsha Palmer, Roger Sauve, and Suping Zhou' \\ Department of Agricultural Sciences, College of Agriculture, Human and Natural Sciences, \\ Tennessee State University, 3500 John A. Merritt Boulevard, Nashville, TN 37209 \\ Kevin J. Howe, Tara Fish, and Theodore W. Thannhauser ${ }^{2}$ \\ Plant, Soil and Nutrition Research Unit, USDA-ARS, Tower Road, Ithaca, NY 14853
}

\begin{abstract}
ADDiTIONAL INDEX wORDs. cellular and metabolic pathways, iTRAQ, protein functions, root development salt-responsive proteins

Abstract. Tomato (Solanum lycopersicum) has a wide variety of genotypes differing in their responses to salinity. This study was performed to identify salt-induced changes in proteomes that are distinguishable among tomatoes with contrasting salt tolerance. Tomato accessions [LA4133 (a salt-tolerant cherry tomato accession) and 'Walter' LA3465 (a salt-susceptible accession)] were subjected to salt treatment $(200 \mathrm{~mm} \mathrm{NaCl}$ ) in hydroponic culture. Salt-induced changes in the root proteomes of each tomato accession were identified using the isobaric tags for relative and absolute quantitation (iTRAQ) method. In LA4133, 178 proteins showed significant differences between salt-treated and nontreated control root tissues $(P \leq 0.05) ; 169$ proteins were induced $(1.3$ - to 5.1-fold) and nine repressed $(-1.7-$ to -1.3 fold). In LA3465, 115 proteins were induced (1.3- to 6.4-fold) and 23 repressed ( -2.5 - to -1.3 -fold). Salt-responsive proteins from the two tomato accessions were involved in the following biological processes: root system development and structural integrity; carbohydrate metabolism; adenosine-5' -triphosphate regeneration and consumption; amino acid metabolism; fatty acid metabolism; signal transduction; cellular detoxification; protein turnover and intracellular trafficking; and molecular activities for regulating gene transcription, protein translation, and posttranslational modification. Proteins affecting diverse cellular activities were identified, which include chaperonins and cochaperonins, heat-shock proteins, antioxidant enzymes, and stress proteins. Proteins exhibiting different saltinduced changes between the tolerant and susceptible tomato accessions were identified, and these proteins were divided into two groups: 1) proteins with quantitative differences because they were induced or repressed by salt stress in both accessions but at different fold levels; and 2) proteins showing qualitative differences, where proteins were induced in one vs. repressed or not changed in the other accession. Candidate proteins for tolerance to salt and secondary cellular stresses (such as hypo-osmotic stress and dehydration) were proposed based on findings from the current and previous studies on tomato and by the use of the Arabidopsis thaliana protein database. Information provided in this report will be very useful for evaluating and breeding for plant tolerance to salt and/or water deficit stresses.
\end{abstract}

Progressive salinization of farmland and diminishing fresh water resources are two major issues affecting sustainability of agricultural crop production. Excess salt $(\mathrm{NaCl})$ content inhibits uptake of essential mineral nutrients and water. Cellular damages under salt stress are attributed to ion $\left(\mathrm{Na}^{+}\right.$and $\left.\mathrm{Cl}^{-}\right)$ toxicity, intracellular hyperosmotic dehydration, mineral imbalance, and other physiological disorders. To overcome the complex salt stress situation, plants often experience changes at the morphological, cellular, and molecular levels. These

Received for publication 25 Apr. 2013. Accepted for publication 1 Aug. 2013. This project was supported by the Agriculture and Food Research Initiative competitive grant no. 2010-65114-20405 from the USDA National Institute of Food and Agriculture, NIFA-grant no. 2010-38821-21571, ARS CRIS project 1907-21000-037-00D, and Evans-Allen Research Funds. Statistical analysis using SAS was performed under the supervision of Dr. Dafeng Hui.

Mention of trade names or commercial products in this publication is solely for the purpose of providing specific information and does not imply recommendation or endorsement by the U.S. Department of Agriculture.

We thank Drs. Jason de Koff and Nick Gawel and Mr. Timothy Hooper at Tennessee State University for reviewing the manuscript.

${ }^{1}$ Corresponding author. E-mail: zsuping@tnstate.edu.

${ }^{2}$ To whom inquiries about iTRAQ should be addressed. E-mail: Ted.Thannhauser@ ars.usda.gov. include re-adjustment in root structure and plant architecture (Lovelli et al., 2012; Maggio et al., 2007), alteration of the ultrastructure of cell wall and subcellular organelles, and reduction of the cell division and enlargement processes (Petricka et al., 2012). Salt stress induces alteration in the de novo protein biosynthesis and enzymatic activity to increase the production of compatible osmolytes including proline and betaine as well as phytohormones such as abscisic acid (ABA), ethylene, and jasmonic acid (JA) and antioxidant and other protective compounds (Frary et al., 2010; Ma et al., 2006; Panda and Khan, 2009).

When subjected to salt stress, plants, through the changes within cellular and subcellular spaces in the contents of ABA (Ma et al., 2006), $\mathrm{H}_{2} \mathrm{O}_{2}$ (Avsian-Kretchmer et al., 2004), $\mathrm{Ca}^{2+}$ (Mahajan et al., 2008), and other signaling molecules, activate various signaling cascades such as the mitogen-activated protein kinases (MAPK) and protein phosphatases cascades (Luan, 1998; País et al., 2009; Pitzschke et al., 2009), leading to readjustment of genome expression and dynamic changes in transcriptomes and proteomes toward development of stress tolerance (Marjanović et al., 2012; Nam et al., 2012; Rasmussen et al., 2013). Ultimately, proteins mediate the adaptation to stress 
(Lackner et al., 2012). Proteomic analysis, in addition to revealing genes concordantly regulated at transcript and translational levels, is especially important for the identification of stress-responsive proteins (such as the salt tolerance protein eIF5A) for which the encoding genes are not changed at the transcript level (Lan and Schmidt, 2011).

Comparative proteomic analyses are highly effective in the identification of protein changes that are associated with genotypic properties. For instance, it was found that different stress proteomes are expressed in the glycolphyte Arabidopsis thaliana than in the halophyte Thellungiella salsuginea under salt treatments (Pang et al., 2010). An iTRAQ analysis of root proteomes from drought-susceptible cultivated tomato and tolerant wild tomato (Solanum chilense) showed that a large number of proteins was affected by dehydration in the two accessions (Zhou et al., 2013). Those differentially expressed proteins can be used as candidate markers for the selection of tolerance traits.

The extraction and identification of a complete proteome from a tissue sample is still a very challenging task as a result of the complex chemical properties of proteins and their association with other molecules in the cell. The use of protein association network databases (Franceschini et al., 2013) and salt stress protein databases (Zhang et al., 2012) provide information regarding proteins that interact with those identified from experimental studies and their relevance to stress tolerance, which greatly expand the capability of proteomics analysis (Dannenfelser et al., 2012; Franceschini et al., 2013).

Tomato is one of the most widely cultivated vegetable worldwide. It is also among the major crops that have significant impacts on agricultural economy. In the United States, fresh and processed tomatoes account for more than $\$ 2$ billion in annual farm cash receipts (U.S. Department of Agriculture, 2013). Most tomato cultivars are susceptible to excessive salt, producing low or no yields on soil that becomes saline as a result of long-term application of fertilizers and/or irrigation with contaminated water. Development of tomato cultivars that are tolerant to saline soil has become an imperative task, which can only be achieved through an effective breeding and selection system for elite plants that express all the desirable agronomic traits in addition to stress tolerance.

Cherry tomato (S. lycopersicum var. cerasiforme) is a genetic admixture between the cultivated tomato and its wild-type accessions (Ranc et al., 2012). The cherry tomato LA4133 was discovered growing in a saline environment near the seashore in Makapuu Beach in Oahu, HI (Tomato Genetics Resource Center, 2001). As a result of natural selection, this tomato accession is highly tolerant of $\mathrm{NaCl}$ (Ezin et al., 2010; Nesbitt and Tanksley, 2002). In a screening study for salt-tolerant tomato accessions at Tennessee State University (Nashville), cherry tomato LA4133 and cultivar Walter LA3465 tomato plants were grown for 6 months in a hydroponic culture supplemented with $200 \mathrm{~mm} \mathrm{NaCl}$. LA4133 plants produced fruits with fertile seeds, whereas LA3465 only had some vegetative growth, and the former accession developed a larger (measured by root length) root system than the latter accession plants (unpublished data). The observation on these phenotypic differences indicates that LA4133 is more tolerant to excess salt than LA3465.

In this study, the two tomato accessions (LA4133 and LA3465) were subjected to salt treatment, and the salt-induced changes in root proteomes were identified. Proteins showing contrasting differences in the two genotypes were selected. Putative roles of those proteins in conferring salt tolerance and the use of those proteins in developing salt-tolerant tomato cultivars are presented.

\section{Materials and Methods}

Plant growth and salt treatment. Seed stocks of two tomato accessions [LA3456 (salt-susceptible) and LA4133 (salt-tolerant)] were obtained from the Tomato Genetics Resource Center at the University of California, Davis. Seeds were propagated at Tennessee State University. For this study, seeds were surface-sterilized by submerging in $25 \%$ commercial bleach for $10 \mathrm{~min}$ followed by three washes with sterile distilled water. Germinated seeds in seed cubes (Smithers-Oasis, Kent, $\mathrm{OH})$ were transferred into net pots $(3.81 \mathrm{~cm}$ wide), which were placed in hydroponic tanks filled with half-strength Hoagland's nutrient solution (Hoagland and Aron, 1950). Each hydroponic tank was planted with 22 seedlings with half of the plants from each of the two accessions. Solutions were refreshed every $3 \mathrm{~d}$ and constant aeration was provided by submerged pumps.

One-month-old plants bearing two true leaves were subjected to salt treatment. The solution for the three treatment tanks was replaced with half-strength Hoagland's solution supplemented with sufficient $\mathrm{NaCl}$ to bring the final concentration to $200 \mathrm{~mm}$. The three control tanks were refreshed with half-strength Hoagland's solution. Greenhouse temperature was $25^{\circ} \mathrm{C}$ with no supplemental lighting.

Root samples were collected $2 \mathrm{~d}$ after the initiation of salt treatments. To harvest root samples, plants were lifted out of the hydroponic solution, and root segments of $3 \mathrm{~cm}$ from root tips were cut from the root system and collected. For each accession, tissues harvested from the same tank were pooled together as one biological sample. Samples were frozen in liquid nitrogen immediately after harvest and stored at $-80{ }^{\circ} \mathrm{C}$ until used.

Protein EXTRaction AND ISOBARIC TAgs FOR RELATIVE AND ABSOLUTE QUANTIFICATION LABELING. Frozen root tissues were ground into a fine powder and resuspended in acetone supplemented with $10 \%$ trichloroacetic acid and $1 \%$ dithiothreitol (Sigma, St. Louis, MO). After overnight incubation at $-20{ }^{\circ} \mathrm{C}$, protein pellets were collected by centrifugation at $10,000 \mathrm{~g}_{\mathrm{n}}$ for $10 \mathrm{~min}$ at $4{ }^{\circ} \mathrm{C}$ and then washed four times in prechilled acetone. Protein pellets were then solubilized in a dissolution buffer $(1: 10, \mathrm{w} / \mathrm{v})$ consisting of $50 \mathrm{~mm}$ triethylammonium bicarbonate (TEAB) and $500 \mathrm{~mm}$ urea (Sigma). After incubation on ice for $10 \mathrm{~min}$ with vortexing every $2 \mathrm{~min}$, the mixture was centrifuged at $10,000 g_{\mathrm{n}}$ for $10 \mathrm{~min}$. Proteins in the supernatant were precipitated using the methanol and chloroform method (Wessel and Fugge, 1984). Proteins were dissolved in the same dissolution buffer, and protein contents were determined using a protein assay kit (Bio-Rad, Hercules, CA).

For iTRAQ labeling, $100 \mu \mathrm{g}$ protein from each sample was denatured in $0.1 \%$ (w/v) sodium dodecyl sulfate, reduced with 5 $\mathrm{mm}$ [tris (2-carboxyethyl)] phosphine, and oxidized with $10 \mathrm{~mm}$ methyl methanethiosulfonate. After overnight trypsin digestion (Promega, Madison, WI) at $37^{\circ} \mathrm{C}$, protein samples were dried down and re-dissolved in $500 \mathrm{~mm}$ TEAB buffer. iTRAQ labeling was performed following the manufacturer's instruction (8-plex iTRAQ ${ }^{\circledR}$ labeling kit; AB SCIEX, Foster City, CA). The treated samples were labeled with tags 113,114 , and 115 and the control samples with 116,117 , and 118 . Labeled proteins 
of the six samples (three control and three treated) from the same tomato accession were combined (multiplexed) and purified through an isotope-coded affinity tags (ICAT) cation exchange cartridge (AB SCIEX).

CHROMATOGRAPHY AND MASS SPECTROMETRIC ANALYSIS. Each sample eluted from the ICAT column was reconstituted in 500 $\mu \mathrm{L} 0.1 \%(\mathrm{v} / \mathrm{v})$ trifluoroacetic acid (TFA). Salts were removed using a solid phase extraction procedure through $1-\mathrm{cm}^{3}, 50-\mathrm{mg}$ cartridges following the manufacturer's instructions (Sep-Pak $\mathrm{C}_{18}$; Waters, Milford, MA). Proteins were eluted in $500 \mu \mathrm{L} \mathrm{50 \%}$ (v/v) acetonitrile with $0.1 \%$ TFA and dried under vacuum. These protein samples were subjected to high $\mathrm{pH}$ firstdimension ultra-performance liquid chromatography (UPLC) separation using an Acquity System (Waters) coupled with a robotic fraction collector (Probot; Dionex, Sunnyvale, CA). One hundred micrograms of the multiplexed sample was injected and fractionated into 48 fractions in a 96-well plate. The 48 fractions were concatenated (Wang et al., 2011) to yield 16 sample pools, which were dried and reconstituted each in 25 $\mu \mathrm{L}$ of $3 \%(\mathrm{v} / \mathrm{v})$ acetonitrile with $0.1 \%$ TFA. These samples were further fractioned using low $\mathrm{pH}$ second-dimension reverse phase separation (Yang et al., 2011). Nano-liquid chromatography separation of tryptic peptides was performed with a nanoAcquity system (Waters) equipped with a Symmetry $\mathrm{C}_{18} 5 \mu \mathrm{m}$, $20 \mathrm{~mm} \times 180-\mu \mathrm{m}$ trapping column and a UPLC BEH C $\mathrm{B}_{18} 1.7$ $\mu \mathrm{m}, 15 \mathrm{~cm} \times 75-\mu \mathrm{m}$ analytical column (Waters). Mass spectrometric analysis of tryptic peptides was performed using a high-definition mass spectrometry system (Synapt; Waters). Accurate mass data were obtained by liquid chromatographymass spectrometry data-dependent acquisition (LC-MS/MS DDA). Instrument settings and data acquisition used the same parameters as described in a previous study (Zhou et al., 2013).

Database Search and Protein Quantification. Mascot Daemon (Version 2.3.2; Matrix Science, Boston, MA) was used to combine .pkl files for the 16 fractions associated with each sample (the multiplexed six labeled protein samples from one accession) and to query them against an ITAG 2.3 tomato protein database [downloaded on 16 Sept. 2011 (Bombarely et al., 2011)]. Furthermore, an exclusion list including the commonly observed peptides of keratin, porcine trypsin, and Con-A was used to avoid accumulating spectra of uninformative ions. Database search criteria were the same as described by Zhou et al. (2013). Briefly, precursor mass tolerance was set to $0.05 \mathrm{Da}$, whereas fragment tolerance was set to $0.1 \mathrm{Da}$. One missed tryptic cleavage was allowed. The MS/MS data were searched with S-methylation of cysteine as a fixed modification and the oxidation of methionine residues and the deamidation of asparagine and glutamine as variable modifications. All peptide matches reported herein have an E-value $<0.05$. Protein identification required at least one peptide match with an Evalue $<0.05$. A false discovery rate was calculated by searching the MS/MS data using a reversed decoy database. The protein identification data are presented in Supplemental Table 1.

Theoretically, at least two confidently quantified peptides were required for protein quantification using the peptide data. When comparing the iTRAQ data files from the two tomato accessions, we have found that some proteins contained one peptide in one but two or more in the other accession. To avoid missing information, proteins containing one well-quantified peptide in the six samples in either accession were also analyzed, and information of the number of peptide used for protein quantification is provided in Supplemental Tables 2 and 3.
AnAlysis AND CHARACTERIZATION OF DIFFERENTIAL PROTEIN EXPRESSION. For each iTRAQ data file, low signal intensity peptide data (less than 20 signal intensity) and those with missing data in the three biological replicates of the same sample group (control or treated) were removed. Peptides shared among related but distinct proteins or peptides where the spectrum was also matched to a different protein were excluded in quantification. The remaining peptides were included as contributing factors to protein quantification (Boehm et al., 2007). The normalized peak intensities of reporter ions of constituent peptides were $\log _{2}$ transformed.

To determine the effects of salt treatments on proteome expression in each accession, the quantitative data were subjected to principal component analysis (PCA). To determine the proteome separation between genotypes under treated and non-treated conditions, PCA analysis was performed on peptides that were identified in each of the 12 biological samples from the two accessions (each accession had six samples of three replicates in treated and control groups).

To determine the confidence associated with the quantitative protein changes, the $\log _{2}$ fold values from all constituent peptides were subjected to $t$-test (general linear model procedure) followed by false discovery rate (FDR) corrections to determine the threshold of statistically significant differences for each protein between salt-treated and control sample groups (Zhou et al., 2013). Statistical analyses were performed using SAS (Version 9.3; SAS Institute, Cary, NC).

Proteins passing the statistical tests $(P \leq 0.05)$ were selected, and then the $\log _{2}$ fold values were back-transformed through antilogarithmic transformation to yield the "fold change" ratio of protein abundance (treated/control). Induced proteins in the salt-treated samples have a fold change greater than 1 , and repressed proteins have a fold change less than 1 . For ease of comparison, the fold change of repressed proteins is expressed as the negative ( - ) inverse of the actual fold change. Thus, if a protein's expression was reduced by half after treatment, its fold change would be given as -2.0 -fold, whereas a protein whose expression doubled on treatment would exhibit a fold change of +2 .0-fold. Salt-responsive proteins are selected using the following criteria: passing the statistical tests and with greater than $1.3( \pm)$-fold change quantified using two and more peptides in either or both accessions.

DETERMinAtion OF PROTEIN Distribution IN THE TWO TOMATo ACCESSIONS. The lists of proteins quantified in the two tomato accessions were combined, and proteins were divided into five clusters: Cluster 1, no change, a protein was placed in this group when it was identified as no-change in either accession; Cluster 2, proteins induced in LA3465; Cluster 3, proteins induced in LA4133; Cluster 4, proteins repressed in LA3465; and Cluster 5, proteins repressed in LA4133. The number of proteins in each individual and overlapping clusters was used to describe protein distribution in a Venn diagram.

DETERMinATION OF THE BIOLOGICAL FUNCTIONS OF TOMATO SALT-RESPONSIVE PROTEINS AND THE ROLE IN SALT TOLERANCE. TO determine the biological function of tomato proteins, they were searched using protein names for protein accessions in $A$. thaliana STRING database [Version 9.1 (Franceschini et al., 2013)]. Tomato proteins with no matching names were searched using amino acid sequences retrieved in the annotated tomato genome database (Bombarely et al., 2011). For proteins assigned to multiple accessions in $A$. thaliana, the one annotated to salt or relevant stress factors and/or root development 
was selected. The biological processes of the identified proteins were determined using the Gene Ontology (GO) enrichment analysis tool in the database (Franceschini et al., 2013). Proteins are normally annotated to several GO terms because they are in most cases associated with multiple biological processes. In this study, each protein was placed in only one biological process with priority given to root development followed by responses to salt and then to salt-induced secondary stresses (such as hypo-osmotic and water deprivation). Proteins that could not be placed into the GO terms were grouped based on their molecular functions. Roles of tomato proteins in conferring tolerance to salt and/or water deficit stresses were proposed based on the relative changes of selected proteins induced by salt reported in this study and in $S$. chilense (Zhou et al., 2011) and those effected by water deficit in $S$. chilense and 'Walter' (Zhou et al., 2013).

\section{Results and Discussion}

\section{Effect of salt treatment on proteome expression in tomato 'Walter' LA3465 and cherry tomato LA4133}

PCA of the peptides that were identified in both accessions shows that the two tomato accessions were separated on the second principal component at 2.3 eigenvalue, and treated and control groups from each accession were separated on the third principal component at 0.9 eigenvalue (Fig. 1). These results indicate that the identified proteomes are associated with

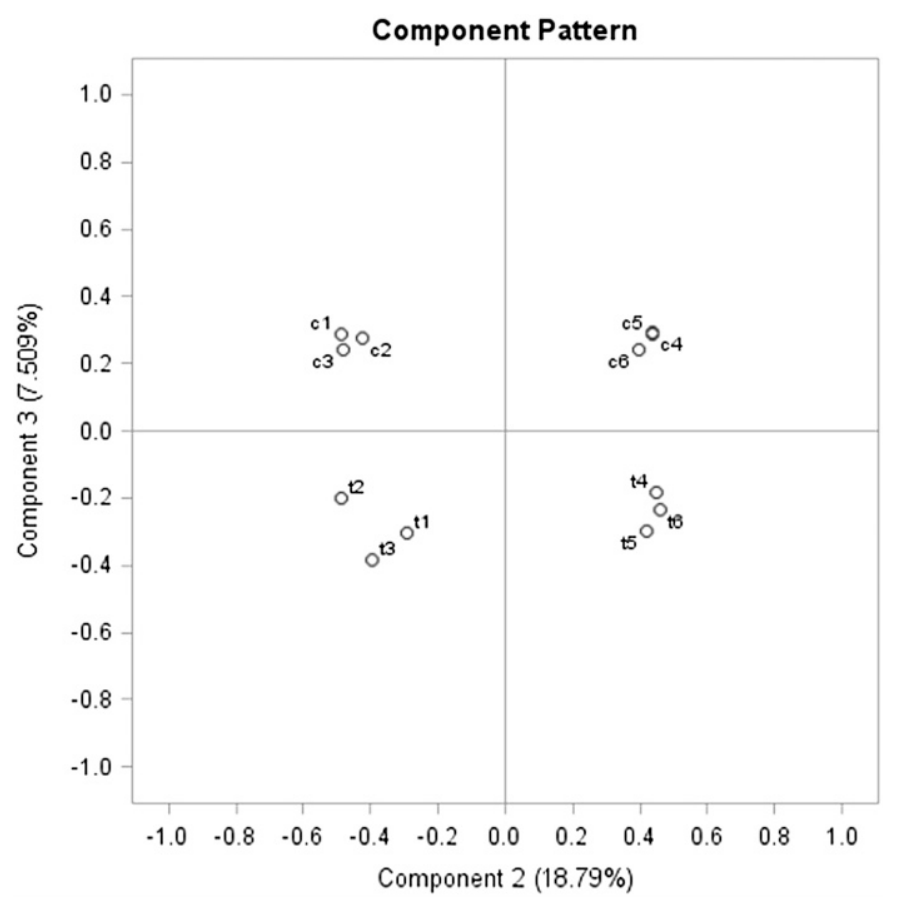

Fig. 1. Principal component analysis of salt-induced root proteomes in salttolerant cherry tomato accession LA4133 and salt-susceptible tomato cultivar Walter accession LA3465. Proteomes from salt-treated and control groups of LA4133 ( $\mathrm{t} 1, \mathrm{t} 2, \mathrm{t} 3$ as the treated replicates; $\mathrm{c} 1, \mathrm{c} 2, \mathrm{c} 3$ as the control replicates) and LA3465 ( $\mathrm{t} 4, \mathrm{t} 5$, t6 as the treated replicates; $\mathrm{c} 4, \mathrm{c} 5$, c6 as the control replicates) were identified using the isobaric tags for relative and absolute quantitation (iTRAQ) method. Peptides identified in each of 12 samples were used for the principal component analysis (PCA). The two accessions were separated at the second principal component, and the treated and control groups for each accession were separated at the third principal component. genotypes under either salt-treated or untreated conditions. The separation of the salt-treated and non-treated control groups was also confirmed from PCA of the quantitative data from each individual accession. In conclusion, the PCA analysis confirmed that the identified proteomes can reflect both the effect of salt treatment as well as genotypic differences between the two tomato accessions.

Then the proteome data from each individual accession was analyzed to determine salt-induced changes (fold change in abundance level from treated to control groups) in each protein and the level of significance of those changes ( $t$-test followed by FDR correction and fold change). Proteins passing the statistical tests $(P \leq 0.05)$ and having \pm 1.3 fold change were listed as significantly changed. Then one compiled file containing all the proteins identified in the two accessions was generated.

The Venn diagram (Fig. 2) represents protein distribution in the two tomato accessions. It can be seen that the majority of the proteins did not exhibit a significant change from salt-treated to non-treated conditions ( $80 \%$ in LA4133, 85\% in LA3465). Among the significantly changed proteins, more proteins were induced $(95 \%$ in LA4133, 83\% in LA3465) than repressed (5\% in LA4133, 17\% in LA3465) in either the salt-tolerant or the susceptible accession. Some proteins had similar responses (either induced or suppressed) to salt treatment in both accessions. More importantly, some proteins were induced in LA4133 but repressed or had no change in LA3465, or vice versa. The protein distribution pattern indicates that both accessions exhibited dynamic changes in protein expression on exposure to salt treatment, and some of those changes are associated with genotypic properties of the two accessions with respect to salt tolerance.

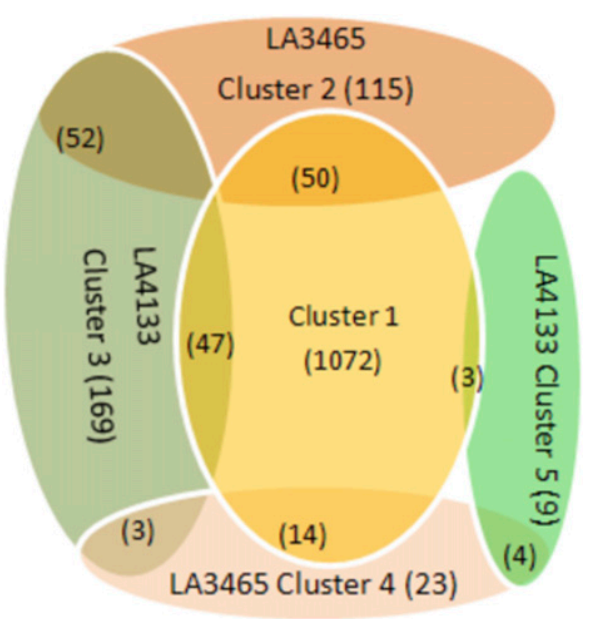

Fig. 2. Venn diagram of protein distribution in the salt-induced root proteomes in tomato accessions with contrasting salt tolerance. Root proteomes in salttolerant cherry tomato accession LA4133 and salt-susceptible cultivar Walter accession LA3465 were identified using the isobaric tags for relative and absolute quantitation (iTRAQ) method. Proteins showing significant changes in abundance between salt-treated and control groups $[P \leq 0.05$ in $t$ test with false discovery rate (FDR) corrections; $>1.3( \pm)$-fold] were divided into five clusters: Cluster $1=$ no change, a protein was placed in this group when it was identified as no change in either accession; Cluster $2=$ proteins induced in LA3465; Cluster $3=$ proteins induced in LA4133; Cluster $4=$ proteins repressed in LA3465; Cluster $5=$ proteins repressed in LA4133. The numerical number in the parentheses shows the number of proteins in each individual and overlapping clusters. 


\section{Functional categories of salt-responsive proteins}

Salt-responsive proteins were classified into 10 groups based on biological and molecular function (Supplemental Table 4). The distribution of the salt-induced proteins were: Group 1, root system development and structural integrity (9\%); Group 2 , carbohydrate metabolism (16\%); Group 3, adenosine- $5^{\prime}$ triphosphate (ATP) regeneration and consumption $(6 \%)$; Group 4, amino acid metabolism (10\%); Group 5, fatty acid metabolism (3\%); Group 6, proteins affecting diverse cellular activities, which include chaperonins and cochaperonins, heatshock proteins, antioxidant enzymes, and signal transduction proteins (30\%); Group 7, cellular detoxification (3\%); Group 8, intracellular trafficking (3\%); Group 9, protein turnover and post-translational modification (4\%); and Group 10, DNA replication and gene expression (16\%) (Fig. 3).

\section{Effect of salt treatment on protein expression affecting root growth and structural integrity}

A well-developed root system is essential for growing healthy plants. Excess salt induces a decrease (or arrest) of cell division (in the meristematic zone) and cell elongation and expansion (in the elongation zone) of root tips (West et al., 2004) and suppression of root hair outgrowth in the differentiation zone of roots (Petricka et al., 2012). Therefore, molecular mechanisms that regulate cell cycle relevant to root growth are very important for developing salt-tolerant plants.

In this study several proteins affecting root development were identified (Table 1). The Ran GTPase binding protein, the actin-depolymerizing factor 1 (ADF), and the fructosebisphosphate aldolase were induced in LA4133 but not changed in LA3465. Earlier studies found that Ran and ADF play key roles in root tip growth by affecting mitotic progress in primordial meristem and cell expansion (Augustine et al., 2011; Kim et al., 2001; Wang et al., 2006), and they also affect root

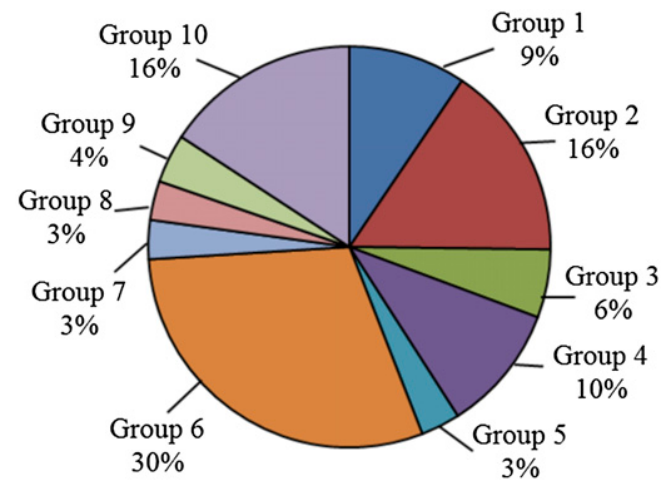

Fig. 3. Functional classification of salt-responsive root proteins in tomato. Root proteomes in salt-tolerant cherry tomato accession LA4133 and saltsusceptible tomato cultivar Walter accession LA3465 were identified using the isobaric tags for relative and absolute quantitation (iTRAQ) method. Proteins showing significant changes in abundance between treated and control groups $[P \leq 0.05$ in $t$ test with false discovery rate (FDR) corrections; $>1.3( \pm)$-fold] from the two tomato accessions were placed into 10 subgroups based on their putative molecular functions in various biological processes: Group $1=$ root system development and structural integrity; Group $2=$ carbohydrate metabolism; Group 3 = adenosine-5' -triphosphate (ATP) regeneration consumption; Group 4 = amino acid metabolism; Group 5 = fatty acid metabolism; Group $6=$ proteins affecting diverse cellular activities; Group 7 = detoxification; Group $8=$ intracellular trafficking; Group $9=$ protein turnover and post-translational modification; Group $10=$ nuclear process and gene expression. The distribution of identified proteins in each group is indicated as a percentage in the total number of salt-responsive proteins. development under salt and osmotic stresses (Franceschini et al., 2013; Huang et al., 2012). Aldolase physically associates with vacuolar H-ATPase in roots and may regulate the vacuolar H-ATPase-mediated control of cell elongation that determines root length in A. thaliana (Konishi et al., 2004). The fructosebisphosphate aldolase was annotated to the root development process in the STRING database (Franceschini et al., 2013). These results indicate that Ran, ADF, and fructose-bisphosphate aldolase play key roles in root growth under salt treatment conditions. The induction of Ran seen here is consistent with that observed during water deficit in S. chilense (Zhou et al., 2013); therefore, this protein may also participate in drought tolerance. In addition, the fasciclin-like arabinogalactan protein, which is a cell wall protein required for cell adhesion and communication (Johnson et al., 2003), was also induced in LA4133.

Two proteins, alpha-mannosidase and xylanase inhibitor, were induced in both tomato accessions. The former enzyme is required for glycan maturation, which is necessary for sufficient cell wall formation under salt stress (Liebminger et al., 2009). Activation of xylanase inhibitor prevents cell wall hemicellulose degradation (Durand et al., 2005). An increase in these two proteins may be associated with the protection of cell wall structure integrity and function against salt stress as a universal mechanism in both tolerant and susceptible plants.

\section{Effect of salt treatment on protein expression affecting metabolic pathways}

Carbohydrate metabolic pathways. Sucrose is the principal carbon source in roots. Two enzymes, sucrose synthase and sucrase, that participate in biochemical reactions hydrolyzing sucrose into xylose (glucose and fructose) were induced by salt treatment. Sucrose synthase seems to increase more in LA3465 than in LA4133 (2.2- vs. 1.4-fold), whereas sucrase (invertase) was induced at an equal level in the two accessions (Table 1).

Sugars converted from sucrose are then metabolized by glycolysis, pentose phosphate, and the anaerobic and aerobic respiratory pathways. From the two accessions, six enzymes were induced under salt treatment, which include phosphoglycerate kinase and glyceraldehyde 3-phosphate dehydrogenase (glycolysis), malate dehydrogenase [tricarboxylic acid cycle (TCA)], alcohol dehydrogenase (fermentation), phosphoglucomutase (glycolysis and gluconeogenesis), and uridine triphosphate-glucose 1 phosphate uridylyltransferase (polysaccharide biosynthesis). Five more enzymes in these pathways were induced in LA3465, but not changed in LA4133; they are succinyl-CoA ligase, citrate synthase and malic enzyme (TCA), enolase and pyruvate kinase (glycolysis), and transketolase and 6-phosphogluconate dehydrogenase decarboxylating1 (the pentose pathway). In general, the catabolism of carbohydrates was induced under salt treatment in both tomato accessions, which agrees with results from earlier studies (Forsthoefel et al., 1995; Nam et al., 2012). Despite this commonality, the pentose phosphate pathway and several enzymes in TCA and glycolysis pathways were only induced in LA3465, and the dihydrolipoyl dehydrogenases were induced only in LA4133. These results indicate that there is a difference in the modulation of carbohydrate metabolic pathways when plants with contrasting tolerance are exposed to salt treatment.

ATP REgENERATION AND CONSUMPTION. The mitochondrial adenosine diphosphate (ADP)/ATP carrier protein for importing ADP into mitochondria and exporting ATP from the organelle 
Table 1 . The identity of salt-responsive root proteins in salt-tolerant cherry tomato accession LA4133 and salt-susceptible tomato cultivar Walter accession LA3465. ${ }^{\mathrm{z}}$

\begin{tabular}{|c|c|c|c|}
\hline \multirow[b]{2}{*}{ Biological processes } & \multicolumn{2}{|c|}{ Fold change $^{\mathrm{y}}$} & \multirow[b]{2}{*}{ Tomato protein accession $^{\mathrm{x}}$} \\
\hline & LA4133 & LA3465 & \\
\hline \multicolumn{4}{|l|}{ Root system development } \\
\hline Alpha-mannosidase & $1.4^{\mathrm{w}}$ & $1.3^{\mathrm{w}}$ & Solyc06g068860.2.1 \\
\hline Ran GTPase binding protein ${ }^{\mathrm{u}}$ & $1.7^{\mathrm{w}}$ & -1.1 & Solyc08g062660.2.1 \\
\hline \multicolumn{4}{|l|}{ Cell wall and cytoskeleton } \\
\hline Actin-depolymerizing factor 1 & $1.7^{\mathrm{w}}$ & 1.0 & Solyc09g010440.2.1 \\
\hline Xylanase inhibitor $^{\mathrm{u}}$ & $1.7^{\mathrm{w}}$ & $1.7^{\mathrm{w}}$ & Solyc01g080010.2.1 \\
\hline Chitinase & $1.3^{\mathrm{w}}$ & 1.2 & Solyc10g055820.1.1 \\
\hline Endochitinase $^{\mathrm{v}}$ & 1.3 & $1.4^{\mathrm{w}}$ & Solyc $10 \mathrm{~g} 055810.1 .1$ \\
\hline \multicolumn{4}{|l|}{ Carbohydrate metabolism } \\
\hline Sucrase & $1.5^{\mathrm{w}}$ & 1.4 & Solyc02g067840.2.1 \\
\hline Sucrose synthase & $1.4^{\mathrm{w}}$ & $2.2^{\mathrm{w}}$ & Solyc07g042550.2.1 \\
\hline Enolase $^{\mathrm{u}, \mathrm{s}}$ & 1.2 & $1.4^{\mathrm{w}}$ & Solyc $10 \mathrm{~g} 085550.1 .1$ \\
\hline Pyruvate kinase & 1.3 & $1.5^{\mathrm{w}}$ & Solyc04g008740.2.1 \\
\hline Phosphoglycerate kinase $^{\mathrm{u}}$ & $1.4^{\mathrm{w}}$ & $1.3^{\mathrm{w}}$ & Solyc07g066600.2.1 \\
\hline Glyceraldehyde 3-phosphate dehydrogenase $\mathrm{e}^{\mathrm{v}, \mathrm{u}}$ & $1.3^{\mathrm{w}}$ & $1.4^{\mathrm{w}}$ & Solyc05g014470.2.1 \\
\hline Malate dehydrogenase $\mathrm{e}^{\mathrm{v}, \mathrm{u}, \mathrm{s}}$ & $1.4^{\mathrm{w}}$ & $1.4^{\mathrm{w}}$ & Solyc07g062650.2.1 \\
\hline Malic enzyme & 1.1 & $1.7^{\mathrm{w}}$ & Solyc05g050120.2.1 \\
\hline Dihydrolipoyl dehydrogenase $^{u}$ & $1.3^{\mathrm{w}}$ & 1.2 & Solyc05g053300.2.1 \\
\hline Succinyl-CoA ligase $^{\mathrm{v}}$ & 1.2 & $1.5^{\mathrm{w}}$ & Solyc06g083790.2.1 \\
\hline Citrate synthase & 1.2 & $1.7^{\mathrm{w}}$ & Solyc01g073740.2.1 \\
\hline Alcohol dehydrogenase $2^{\mathrm{v}}$ & $2.1^{\mathrm{w}}$ & $2.6^{\mathrm{w}}$ & Solyc06g059740.2.1 \\
\hline Alcohol dehydrogenase zinc-containing ${ }^{\mathrm{u}}$ & $2.0^{\mathrm{w}}$ & $1.9^{\mathrm{w}}$ & Solyc09g059040.2.1 \\
\hline Adenosine kinase ${ }^{\mathrm{u}}$ & 1.3 & $1.6^{\mathrm{w}}$ & Solyc10g086190.1.1 \\
\hline \multicolumn{4}{|l|}{ Amino acids } \\
\hline Shikimate hydroxyl-cinnamoyltransferase & 1.4 & $1.8^{\mathrm{wr}}$ & Solyc03g117600.2.1 \\
\hline Caffeoyl CoA 3-O-methyltransferase ${ }^{\mathrm{u}}$ & $1.8^{\mathrm{w}}$ & 1.1 & Solyc01g107910.2.1 \\
\hline Alanine aminotransferase ${ }^{u}$ & 1.5 & $1.5^{\mathrm{w}}$ & Solyc03g123610.2.1 \\
\hline $\mathrm{N}$-acetyl-gamma-glutamyl-phosphate reductase & 1.2 & $1.4^{\mathrm{w}}$ & Solyc01g108660.2.1 \\
\hline Asparagine synthetase $^{\mathrm{u}}$ & $1.8^{\mathrm{w}, \mathrm{r}}$ & $1.9^{\mathrm{w}}$ & Solyc01g079880.2.1 \\
\hline Aspartate aminotransferase & $1.3^{\mathrm{w}}$ & $1.6^{\mathrm{w}}$ & Solyc07g055210.2.1 \\
\hline 3-isopropylmalate dehydratase large subunit ${ }^{\mathrm{u}}$ & 1.4 & $1.6^{\mathrm{w}}$ & Solyc07g052350.2.1 \\
\hline 3-deoxy-7-phosphoheptulonate synthase ${ }^{u}$ & $1.4^{\mathrm{w}}$ & $1.7^{\mathrm{w}}$ & Solyc04g074480.2.1 \\
\hline Phosphoserine aminotransferase & 1.4 & $1.6^{\mathrm{w}}$ & Solyc02g082830.1.1 \\
\hline Formate dehydrogenase & $2.0^{\mathrm{w}}$ & $1.5^{\mathrm{w}}$ & Solyc02g086880.2.1 \\
\hline 5-methyltetrahydropteroyltriglutamate-homocysteine methyltransferase $\mathrm{e}^{\mathrm{v}, \mathrm{u}, \mathrm{s}}$ & $1.4^{\mathrm{w}}$ & $2.1^{\mathrm{w}}$ & Solyc $10 \mathrm{~g} 081510.1 .1$ \\
\hline Adenosylhomocysteinase $\mathrm{e}^{\mathrm{v}, \mathrm{u}, \mathrm{s}}$ & $1.3^{\mathrm{w}}$ & $1.5^{\mathrm{w}}$ & Solyc09g092380.2.1 \\
\hline O-methyltransferase $\mathrm{v}^{\mathrm{v}}$ & $2.2^{\mathrm{w}}$ & 1.7 & Solyc03g080180.2.1 \\
\hline Methylenetetrahydrofolate reductase & 1.2 & $1.8^{\mathrm{w}}$ & Solyc11g008870.1.1 \\
\hline \multicolumn{4}{|l|}{ Fatty acids metabolism } \\
\hline Acetyl-CoA carboxylase biotin carboxyl carrier protein & $1.5^{\mathrm{w}}$ & 1.2 & Solyc01g008330.2.1 \\
\hline 3-ketoacyl CoA thiolase 1 & 1.4 & $1.3^{\mathrm{w}}$ & Solyc09g091470.2.1 \\
\hline Lipase-like & -1.2 & $2.3^{\mathrm{w}}$ & Solyc02g077420.2.1 \\
\hline Patatin $^{u}$ & $1.9^{\mathrm{wr}}$ & $-1.4^{\mathrm{w}}$ & Solyc08g006860.2.1 \\
\hline
\end{tabular}


Table 1. Continued.

\begin{tabular}{|c|c|c|c|}
\hline \multirow[b]{2}{*}{ Biological processes } & \multicolumn{2}{|c|}{ Fold change ${ }^{y}$} & \multirow[b]{2}{*}{ Tomato protein accession ${ }^{\mathrm{x}}$} \\
\hline & $\overline{\mathrm{LA} 4133}$ & LA3465 & \\
\hline \multicolumn{4}{|l|}{ Detoxification } \\
\hline Aldehyde dehydrogenase & 1.5 & $2.0^{\mathrm{w}}$ & Solyc03g114150.2.1 \\
\hline Polyphenol oxidase $\mathrm{u}^{\mathrm{u}}$ & 1.1 & $1.4^{\mathrm{w}}$ & Solyc08g074680.2.1 \\
\hline \multicolumn{4}{|l|}{ Proteins affecting diverse cellular activities } \\
\hline HAT family dimerization domain containing protein & $\mathrm{NI}^{\mathrm{t}}$ & $2.0^{\mathrm{w}}$ & Solyc12g070140.1.1 \\
\hline Chaperone DnaK ${ }^{\mathrm{v}, \mathrm{u}}$ & $1.3^{\mathrm{w}}$ & 1.0 & Solyc01g106210.2.1 \\
\hline FK506-binding protein ${ }^{\mathrm{u}, \mathrm{s}}$ & $1.5^{\mathrm{w}}$ & 1.1 & Solyc09g057670.2.1 \\
\hline T-complex protein theta subunit ${ }^{u}$ & $1.4^{\mathrm{w}}$ & 1.7 & Solyc01g088080.2.1 \\
\hline T-complex protein 1 subunit alpha ${ }^{u}$ & 1.2 & $1.5^{\mathrm{w}}$ & Solyc01g090750.2.1 \\
\hline Heat shock protein C62.5 & 1.1 & $1.3^{\mathrm{w}}$ & Solyc04g081570.2.1 \\
\hline Heat shock protein 90 & 1.1 & $1.7^{\mathrm{w}}$ & Solyc12g015880.1.1 \\
\hline Salt stress root protein $(\mathrm{RS} 1)^{\mathrm{v}, \mathrm{u}}$ & $1.5^{\mathrm{w}}$ & 1.2 & Solyc10g005100.2.1 \\
\hline $\mathrm{ASR} 4^{\mathrm{v}, \mathrm{u}}$ & $5.3^{\mathrm{w}}$ & $2.6^{\mathrm{w}}$ & Solyc04g071620.2.1 \\
\hline Ultraviolet excision repair protein $(\mathrm{RAD} 23)^{\mathrm{u}}$ & $1.4^{\mathrm{w}}$ & 1.1 & Solyc02g063130.2.1 \\
\hline Elicitor-responsive protein 3 & $1.4^{\mathrm{w}}$ & 1.0 & Solyc08g080680.2.1 \\
\hline Major allergen Mal $\mathrm{d} 1^{\mathrm{u}}$ & $4.9^{\mathrm{w}}$ & $6.4^{\mathrm{wr}}$ & Solyc09g091000.2.1 \\
\hline REF-like stress related protein 1 & 1.3 & $1.5^{\mathrm{w}}$ & Solyc05g015390.2.1 \\
\hline Ascorbate peroxidase ${ }^{\mathrm{u}}$ & $1.6^{\mathrm{w}}$ & $1.3^{\mathrm{w}}$ & Solyc06g005160.2.1 \\
\hline Ascorbate peroxidase $7^{\mathrm{v}}$ & $1.5^{\mathrm{w}}$ & 1.2 & Solyc06g060260.2.1 \\
\hline Catalase $^{\mathrm{u}}$ & $2.6^{\mathrm{w}}$ & $2.5^{\mathrm{w}}$ & Solyc12g094620.1.1 \\
\hline Cytoplasmic glutaredoxin thioltransferase & $1.8^{\mathrm{w}}$ & 1.0 & Solyc06g005260.2.1 \\
\hline Dehydroascorbate reductase & $1.4^{\mathrm{w}}$ & $1.5^{\mathrm{w}}$ & Solyc05g054760.2.1 \\
\hline Ferritin $^{\mathrm{u}}$ & $1.6^{\mathrm{w}}$ & $\mathrm{NI}^{\mathrm{t}}$ & Solyc06g050980.2.1 \\
\hline Annexin & $1.3^{\mathrm{w}}$ & 1.2 & Solyc04g073990.2.1 \\
\hline Annexin $2^{\mathrm{v}}$ & $1.8^{\mathrm{w}}$ & $2.0^{\mathrm{w}}$ & Solyc04g055170.2.1 \\
\hline Calmodulin ${ }^{u}$ & $1.4^{\mathrm{w}}$ & $-1.4^{\mathrm{w}}$ & Solyc01g008950.2.1 \\
\hline Phosphatidylglycerol/phosphatidylinositol transfer protein $(\mathrm{PITP})^{\mathrm{u}}$ & $1.4^{\mathrm{w}}$ & 1.1 & Solyc01g006900.2.1 \\
\hline Mitogen-activated protein kinase kinase phosphatase 1 (MKP1) & $1.3^{\mathrm{w}}$ & 1.0 & Solyc03g096540.2.1 \\
\hline Remorin $1^{\mathrm{u}}$ & $2.4^{\mathrm{w}}$ & $\mathrm{NI}^{\mathrm{t}}$ & Solyc03g025850.2.1 \\
\hline GTP-binding protein ${ }^{\mathrm{u}}$ & 1.3 & $1.4^{\mathrm{w}}$ & Solyc02g023970.2.1 \\
\hline \multicolumn{4}{|l|}{ Translocation of proteins } \\
\hline ADP-ribosylation factor & 1.1 & $1.4^{\mathrm{w}}$ & Solyc01g008000.2.1 \\
\hline Alpha-soluble NSF attachment protein (SNAP) & 1.1 & $1.6^{\mathrm{w}}$ & Solyc05g052310.2.1 \\
\hline Coatomer subunit gamma (COP) & $1.5^{\mathrm{w}}$ & $1.5^{\mathrm{w}}$ & Solyc01g109540.2.1 \\
\hline \multicolumn{4}{|l|}{ Protein modification and degradation } \\
\hline Mitochondrial processing peptidase $\mathrm{e}^{\mathrm{v}, \mathrm{u}}$ & $1.3^{\mathrm{w}}$ & 1.1 & Solyc12g008630.1.1 \\
\hline Cathepsin B-like cysteine proteinase ${ }^{\mathrm{u}}$ & $1.3^{\mathrm{w}}$ & 1.1 & Solyc12g088670.1.1 \\
\hline Chymotrypsin inhibitor- $2^{\mathrm{u}}$ & $1.4^{\mathrm{w}}$ & 1.0 & Solyc08g080630.2.1 \\
\hline Beta-hexosaminidase $\mathrm{b}$ & 1.2 & $2.9^{\mathrm{wr}}$ & Solyc05g054710.2.1 \\
\hline Leucyl aminopeptidase $\mathrm{u}^{\mathrm{u}}$ & $1.4^{\mathrm{w}}$ & $1.5^{\mathrm{w}}$ & Solyc $12 \mathrm{~g} 010040.1 .1$ \\
\hline \multicolumn{4}{|l|}{ DNA replication and gene expression } \\
\hline MFP1 attachment factor 1 & $2.0^{\mathrm{w}}$ & $\mathrm{NI}^{\mathrm{t}}$ & Solyc04g078380.1.1 \\
\hline Glycine-rich RNA-binding protein & $1.5^{\mathrm{w}}$ & -1.3 & Solyc01g109660.2.1 \\
\hline
\end{tabular}




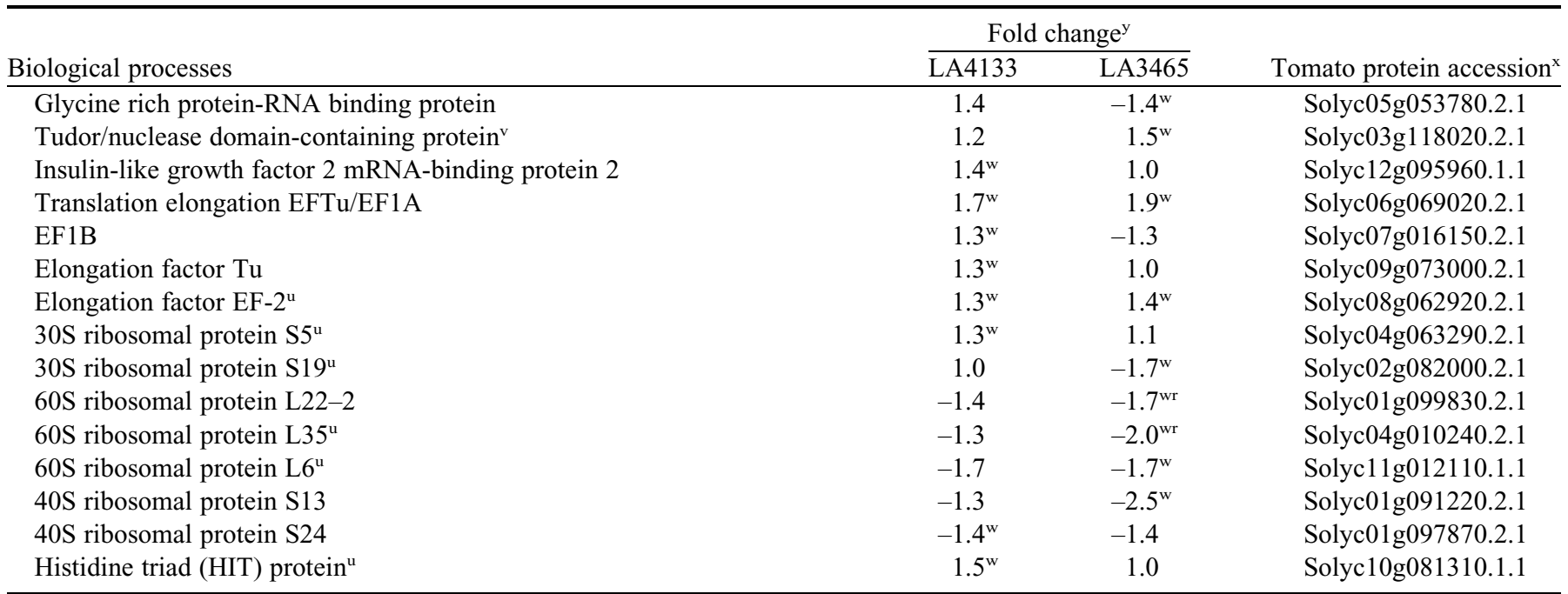

${ }^{2}$ Proteins identified as significantly induced or repressed in either or both tomato accessions by the salt treatment. The relative difference in abundance of each protein, measured by the intensity of its constituent peptides, was compared between treated and control samples within each accession. In every case, the protein from at least one of the two accessions has passed the $t$ test [general linear model (GLM)] with false discovery rate (FDR) corrections $(P \leq 0.05)$ and with a fold change greater than 1.3-fold $( \pm)$. Statistical analyses were performed using SAS (Version 9.3; SAS Institute, Cary, NC).

${ }^{\mathrm{y}}$ The fold change value for each protein is the ratio of the protein abundance level between treated and control samples within each accession. For example, a value of 2.0 represents a 2-fold increase. whereas -2.0 represents a 2 -fold decrease from treated to control conditions.

${ }^{x}$ Protein accession number in the ITAG Protein database (release 2.3 on 26 Apr. 2011; Sol Genomics Network, Boyce Thompson Institute, Ithaca, NY).

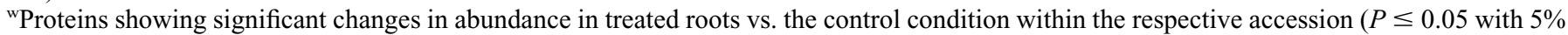
FDR correction; $>1.3( \pm)$-fold). Proteins without the symbol had no significant change from treated to control samples.

vProtein annotated to the salt response biological process in Arabidopsis thaliana String Database [Version 9.0 (Franceschini et al., 2013)]

uProtein abundance altered in roots of Solanum chilense and/or tomato 'Walter' LA 3465 by dehydration treatment (Zhou et al., 2013).

tProteins not identified in the respective accession.

${ }^{\text {s}}$ Protein responded to salt treatment in roots of S. chilense (Zhou et al., 2011).

${ }^{r}$ Protein quantified using one peptide.

into cytosol was induced in both accessions. In LA4133, ATP synthases for ATP regeneration were induced. In LA3465, ATPases that use ATP to pump solutes across membranes, for $\mathrm{Na}^{+}$sequestration (Barkla et al., 1999) or maintaining ion homeostasis (Tang et al., 2012), were strongly enhanced together with adenosine kinase which converts ATP to ADP (Table 1).

The up-regulation of ATPases in the susceptible tomato accession could create a higher demand for ATPs, which represents a higher-energy consumption cellular metabolism model. This could also explain the greater increase in the sucrolytic and glycolytic enzymes in LA3465. It is well known that photosynthesis is reduced under salt stress, especially in susceptible plants. Eventually, the susceptible plants may succumb to prolonged salt stress as a result of deprivation of carbon sources.

\section{Effect of salt treatment on protein expression affecting amino acid metabolism}

Enzymes in the metabolism of aromatic amino acids, free amino acids, methylamine, and branched-chain amino acids (BCAA) were identified (Table 1). The 3-deoxy-7-phosphoheptulonate synthase in the shikimate pathway for the biosynthesis of aromatic amino acids was induced in both accessions. Three enzymes at different steps of phenylpropanoid pathway were identified, shikimate hydroxyl-cinnamoyl transferase was induced in LA3465, and caffeoyl CoA 3-O-methyltransferase (catalyzing the step leading to lignin biosynthesis) and O-methyltransferase were induced in LA4133.

Biosynthesis of methylamines requires adenosylmethionine (SAM) as the methyl donor, which is regenerated through the methyl cycle and SAM (AdoMet) and methionine salvage cycles. In LA4133, two enzymes in the SAM regeneration process, 5-methyltetrahydropteroyltriglutamate-homocysteine methyltransferase (methioine synthase) and adenosylhomocysteinase, were induced. These enzymes were not changed in LA3465, where methylenetetrahydrofolate reductase was induced instead. These results suggested that the tolerant LA4133 seems to have a more active mechanism for the biosynthesis of methylamine as a compatible osmolyte under salt treatment, which was proposed to be one mechanism underlying genetic difference in salt tolerance in tomato (Manaa et al., 2011).

Enzymes induced in both accessions include asparagine synthetase, which plays a critical role in salt and cold tolerance because it is up-regulated by salt stress, osmotic stress, and ABA (Marroufi-Dguimi et al., 2011; Wang et al., 2005). Formate dehydrogenase was also induced by salt treatment. This enzyme controls the homeostasis of formate and it was also suggested to have some roles in the salt responses regulated by AtMKK1 (a stress response kinase) (Conroy et al., 2013).

Five additional enzymes were induced only in LA3465. In LA3465, alanine aminotransferase in the alanine cycle was induced. The induction of this enzyme may result in lower cellular alanine content as the amino acid is shuttled to make 
glucose. In the same tomato accession, phosphoserine aminotransferase, which acts in the biosynthesis pathway of Lglutamate, was induced. Such change could increase cellular glutamic acid content in the treated roots. Induction of these two enzymes could affect free amino acid content. For the biosynthesis of BCAA, 3-isopropylmalate dehydratase in the leucine biosynthesis pathway was induced. Such change in BCAA was found to be linked to salt responses in earlier studies (Nam et al., 2012; Zhou et al., 2009). N-acetyl-gammaglutamyl-phosphate reductase, which participates in the process of producing urea from ammonia through the ornithine cycle, and amidase hydantoinase/carbamoylase, which is important for allantoin degradation, were also induced by the salt treatment in LA3465. Allantoin is a biomarker of oxidative stress in the human system (Gruber et al., 2009), but not much is known about the relationship between its metabolism and salt or oxidative stress in plants.

\section{Effect of salt treatment on protein expression affecting fatty acid metabolism}

Patatin is a phospholipase that catalyzes the cleavage of fatty acids from membrane lipids and also has a role in the removal of oxidized fatty acids from membranes and oxylipin formation against dehydration stress (Yang et al., 2012). This enzyme was induced in LA4133 but repressed in LA3465 (Table 1), and the same enzyme was induced by water deficit in the droughttolerant $S$. chilense (Zhou et al., 2013). These results suggest a role for patatin in drought and salt responses in tomato.

Lipases catalyze the hydrolysis of triglycerides into free fatty acids, which are degraded into acetyl units through the beta-oxidation process. Lipase was induced in LA3465 but unchanged in LA4133. A peroxisomal enzyme, 3-ketoacyl CoA thiolase catalyzing fatty acid beta-oxidation, was induced in LA3465 (1.3-fold); it was also induced in LA4133 at a comparable fold level (1.4-fold, $P>0.05)$, but in the latter case, it did not pass the FDR test. The acetyl-CoA carboxylase biotin carboxyl carrier protein in the biosynthesis pathway of fatty acids was induced in LA4133 but not changed in LA3465. It seems that the two tomato accessions may use different mechanisms to regulate the turnover of fatty acids in response to salt treatment.

\section{Effect of salt treatment on protein expression affecting cellular detoxification}

Four enzymes needed to remove cytotoxic compounds were identified. Cyanate hydratase was induced in both tomato accessions (Table 1). In a study on $A$. thaliana, the homologous gene, $A t C Y N$, was induced at the transcriptional level by salt stress (Qian et al., 2011). Together with results from this study, it seems that this gene responds to salt stress at both transcriptional and translational levels. In addition to metabolizing cyanate, the protein may have other functions in stress tolerance.

Two enzymes were only induced in LA3465, which include aldehyde dehydrogenase in detoxifying peroxidic aldehydes, which result from lipid peroxidation, and polyphenol oxidase. Several studies on tomato have shown that an elevated level of polyphenol oxidase (measured by protein content or enzyme activity) reduces plant tolerance to dehydration stress (Thipyapong and Steffens, 1997; Thipyapong et al., 2007; Zhou et al., 2013). An increase in polyphenol oxidase can make plants more susceptible to water and salt stress conditions.

\section{Effects of salt treatment on proteins affecting} diverse cellular activities

This group of proteins includes chaperonins, folding proteins, antioxidant enzymes, stress responsive and defense proteins, and proteins in signal transduction pathways. These proteins modulate functions of their target proteins in a wide array of cellular processes.

ChAPERONES AND FOLDING PROTEINS. Chaperone protein DnaK (also known as HSP70, which actively participates in the response to hyperosmotic shock) and FK506-binding protein 2, which functions as an endoplasmic reticulum (ER) chaperone with biological functions of mediating folding of nascent or denatured proteins, were induced in LA4133 but not changed in LA3465 (Table 1). The induction of these proteins in the tolerant tomato accession is similar to those observed in $S$. chilense under dehydration and salt conditions (Zhou et al., 2011, 2013). Conversely, two heat shock proteins, heat shock protein C62.5 and heat shock protein 90, assisting with refolding of denatured proteins (Zuehlke and Johnson, 2010), were induced in LA3465 but not changed in LA4133. It is very likely that when exposed to the same concentration of salt, tomato genotypes with contrasting tolerance are experiencing different levels of intracellular stress, thus requiring different types of chaperonins, and those expressed in the tolerant genotypes may be the proteins responsible for the tolerance mechanism in LA4133.

Stress Responsive ANd Defense Proteins. Among the eight proteins that are involved in cellular defense against salt, osmotic, and water deficit stress factors, dehydrin is the only one that was repressed in LA3465 but not changed in LA4133 (Table 1). Two proteins, the REF-like stress-related protein 1 and the major allergen Mal d 1, were induced at a higher magnitude in LA3465 (1.5- and 6.4-fold, respectively) than in LA4133 (1.3- and 5.0-fold, respectively). The root salt protein (RS1) and abscisic acid stress ripening protein (ASR4) showed a greater increase in LA4133 (1.5- and 5.3-fold, respectively) than in LA3465 (1.2- to 2.6-fold, respectively). RS1 and ARS4 were also induced by salt in $A$. thaliana (Franceschini et al., 2013; Goldgur et al., 2006) and by water deficit in S. chilense (Zhou et al., 2013). These results indicate RS1 and ARS4 are important proteins for salt and drought tolerance in tomato, and these defense reactions are mediated by the ABA signaling pathway (Cakir et al., 2003; Kalifa et al., 2004).

The ultraviolet excision repair protein RAD23, elicitorresponsive protein 3 (a phloem protein for mounting a defense reaction in response to external stimuli), and ubiquitin-fold modifier 1 (UFM1) that participate in preventing ER stressinduced apoptosis in protein secretory cells (Lemaire et al., 2011) were induced in LA4133 but not changed in LA3465. By assisting DNA repair of damages induced by ultraviolet light (Ortolan et al., 2000), RAD23 plays a key role in maintaining genome stability of plants affected by intense light conditions. For tomato LA4133 and S. chilense, when growing in their native habitats on the seashore or deserts, plants may experience constant exposure to strong ultraviolet light, which typically coincides with physiological dehydration. Thus, the increase in the protein abundance under salt and dehydration conditions (Zhou et al., 2013) suggests that RAD23 may be a candidate marker protein for tolerance to multiple stresses in tomato.

Antioxidant Enzymes. In this study, 12 antioxidant enzymes (including isoforms) for the removal of reactive oxygen species 
(ROS) were identified (Table 1). Catalase, glutathione-disulfide reductase, and monodehydroascorbate reductase were induced in both accessions (Table 1). Superoxide dismutase, thioredoxin, and the cytoplasmic glutaredoxin thioltransferase were induced only in LA4133; these enzymes were also induced in $S$. chilense under water deficit treatment (Zhou et al., 2011, 2013). It is conclusive that the salt- and drought-tolerant tomato accessions have antioxidant systems comprised of several more antioxidant enzymes or enzymes expressed at higher levels than the susceptible accessions. These results are consistent with those from an earlier study showing that wild salt-tolerant tomato plants are better protected against ROS, inherently and under salt stress, than the relatively sensitive plants of the cultivated species (Shalata and Tal, 1998).

Ferritin was induced by salt stress in LA4133 and was also induced by dehydration in $S$. chilense (Zhou et al., 2013). However, this protein was not found in root protein samples (controls, salt-treated, or water deficit-treated) from LA3465. Ferritin is the only known protein to concentrate iron to the level required by cells, to store iron in a soluble and biologically available form, to release iron when needed, and to protect the cells against the toxic effects of excess iron (Orino et al., 2001; Wei and Theil, 2000; Xi et al., 2011). In this study, the iron content in salt-treated root tissues of LA4133 was increased by over $32 \%$, and LA3465 roots contained even higher iron content (unpublished data). Technically, the same amount of total protein was used for iTRAQ analysis. Our inability to detect ferritin in LA3465 suggests a lower content of this protein in the whole proteome. Thus, the disparity between iron content and ferretin expression in the susceptible tomato accession and the biological significance of this observation need to be investigated.

Signal TRANSDUCTION. Three important proteins in signal transduction pathways were identified; they are calmodulin $(\mathrm{CaM})$, mitogen-activated protein kinase (MAP)/kinase phosphatase 1 (MKP1), and phosphatidylglycerol/phosphatidylinositol transfer protein (PITP). These proteins were induced in the tolerant LA4133 (Table 1) and S. chilense (Zhou et al., 2013), but repressed in the susceptible LA3465, under salt and water deficit treatments. CaM is an important protein in the calciummediated signaling pathway to activate cell defense against salt and other stresses (Xu et al., 2011). MKP1 regulates the MAPK signaling cascade by controlling the activity of MAPKs, thus playing a pivotal role in the integration and fine-tuning of plant responses to various environmental challenges (González Besteiro and Ulm, 2013; Osakabe et al., 2013). PITP regulates a wide array of signal transduction processes (Monks et al., 2001). These results indicate that CaM, MKP1, and PITP proteins are important proteins in signal transduction pathways that activate salt and drought tolerance in tomato.

Remorin 1 was induced in LA4133 by salt treatment (Table 1) and in S. chilense under dehydration (Zhou et al., 2013); however, this protein was not identified in LA3465. Remorins are plant-specific proteins associated with plasma membrane microdomains, called lipid rafts on mature branched plasmodesmata (Raffaele et al., 2009; Tilsner et al., 2011). Those lipid rafts are platforms for various kinds of signaling molecules, and it has been suggested that remorins act as scaffold proteins during early signaling events in defending against pathogenic attack (Jarsch and Ott, 2011). Based on these findings, remorins may play an important role in the signaling process to activate defense reactions in response to abiotic as well as biotic stimuli.
Effect of salt treatment on vesicle proteins for intracellular trafficking

Cytosolic proteins translated on the rough ER are transported to the Golgi by vesicles (transitional vesicles) before targeting to subcellular organelles. The non-clathrin-coated vesicles are covered with coatmer proteins (COP) and are responsible for intracellular trafficking of vesicles produced by ER to the Golgi. Under salt treatment conditions, a COP was equally induced in the two tomato accessions (Table 1).

Two proteins, the alpha-soluble NSF attachment protein mediating intra-Golgi transport of proteins and the ADPribosylation factor, which plays a critical role in intracellular trafficking and maintenance of ER morphology (Lee et al., 2002), were induced in LA3465 but not changed in LA4133. These results suggest that the two tomato accessions may use both common and different mechanisms for targeting proteins into the correct subcellular compartments under salt stress condition.

\section{Effect of salt treatment on protein turnover and protein modification}

The leucyl aminopeptidase, which regulates protein turnover through the JA signal transduction pathway (Fowler et al., 2009), was induced in both accessions (Table 1). Proteins induced only in LA4133 include cathepsin B-like cysteine proteinase and chymotrypsin inhibitor- 2 . The lysosomal betahexosaminidase $b$ in glycan modification was induced in LA3465 but not changed in LA4133. The differential expression of these proteases could result in different proteome composition in the two tomato accessions, which may affect plant responses to salt treatment. In tomato, we have found that the chymotrypsin inhibitor- 2 was consistently induced by salt, drought, and aluminum treatments in tolerant accessions; therefore, this protein might confer tolerance against multiple stress factors.

\section{Effect of salt treatment on gene transcription and protein translation}

DNA REPLICAITON AND GENE TRANSCRIPTION. The MFP1 attachment factor 1 binds double-stranded DNA (Samaniego et al., 2006) and participates in regulation of gene transcription (Meier et al., 1996). It is induced in LA4133 but not changed in LA3465. The glycine-rich RNA-binding protein was induced in LA4133 and repressed in LA3465. This protein is an RNA chaperone and is involved in mRNA alternative splicing during the adaptation process to the environmental stress (Kim et al., 2010). Induction of these two proteins in LA4133 suggests that the tolerant accession may have a more active mechanism to protect and regulate transcript regeneration.

The only protein that was induced in LA3465 is a tudor/ nuclease domain-containing protein, which is a member of the RNA-induced silencing complex (Dit Frey et al., 2010). Endogenous RNAi is important in stress tolerance, but the target genes of the RNAi system in tomato need to be identified to determine its role in stress response.

Protein translation. Regulation of the translational machinery is considered to be an important component of cellular stress response (Omidbakhshfard et al., 2012). In the salttreated tomato roots, several ribosome subunits were repressed in LA3465; only one (the 40S ribosomal protein S24) was repressed in LA4133 (Table 1). The 30S ribosomal protein S5, which plays an important role in translational accuracy 
(Vallabhaneni and Farabaugh, 2009), was induced in LA4133. Protein translation effectors showed a more dynamic change. Two elongation factors, EF Tu/EF1A (1.7-fold in LA4133, 1.9fold in LA4365) and EF2 (1.3-fold in LA4133, 1.4-fold in LA3465) controlling translation fidelity under stress conditions (Fu et al., 2012; Shin et al., 2009), were induced in the two accessions. $\mathrm{EF} 1 \mathrm{~B}$, which is required to regenerate $\mathrm{EF} 1 \mathrm{~A}$ from its inactive form (EF1A-GDP) to its active form (EF1A-GTP) as the rate-limiting step of translation elongation (Andersen and Nyborg, 2001), was induced in LA4133 but repressed in LA3465.

In summary, the efficiency of de novo protein biosynthesis could be reduced more dramatically in LA3465 than in LA4133 as a result of the repression of ribosome subunits under salt treatment in the former accession. Mechanisms to protect the fidelity of protein translation (with a higher abundance in EF $\mathrm{Tu} / \mathrm{EF} 1 \mathrm{~A}$ and EF2) was activated in both tolerant and susceptible tomato accessions, but the tolerant accession may have more strict control on protein translation efficiency as a result of induction in EF1B. Those translation factors provide the candidate for future study of the role of the translation machinery in salt tolerance studies.

\section{Conclusions}

This study has identified proteins that are associated with the genotypic differences in salt tolerance in two tomato

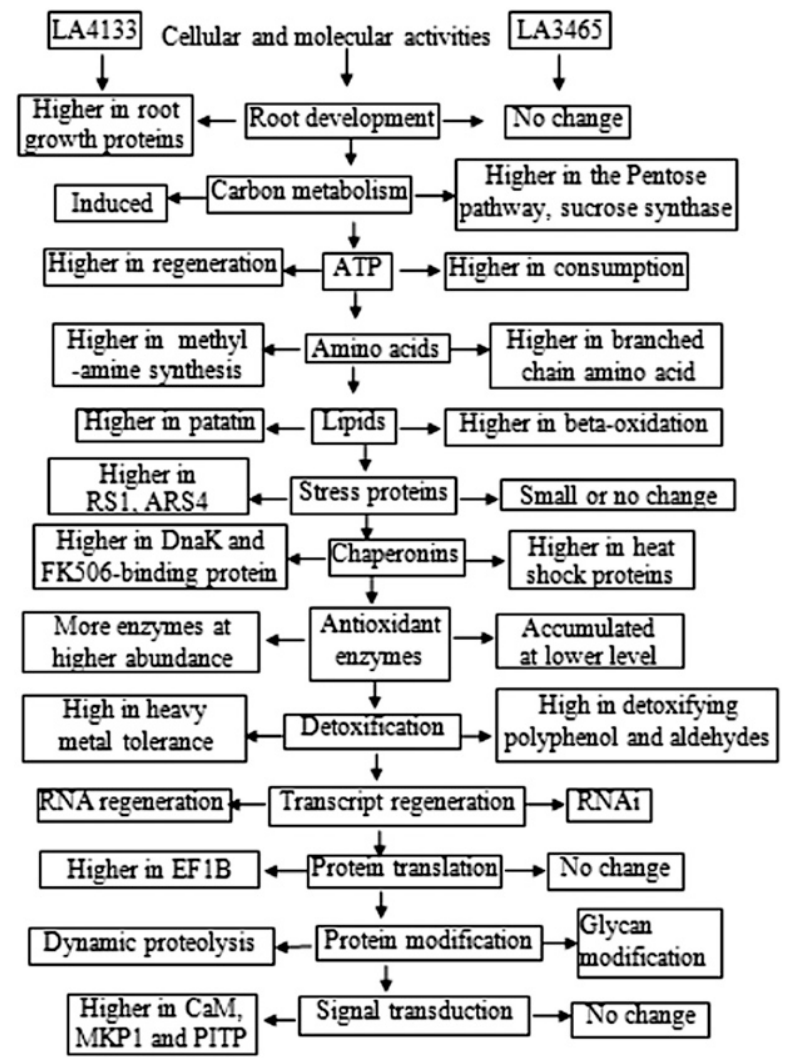

Fig. 4. Differences in molecular and cellular processes between tomato accessions with contrasting salt tolerance. The schematic was developed based on the relative protein changes from salt-treated and non-treated control conditions in salt-tolerant cherry tomato accession LA4133 and saltsusceptible tomato cultivar Walter accession LA3465. Salt-induced proteomes were identified using the isobaric tags for relative and absolute quantitation (iTRAQ) method. The molecular and cellular processes were predicted based on putative functions of the identified proteins. accessions. Based on the putative functions of those proteins, the corresponding molecular and cellular changes were summarized in Figure 4. The proteome changes in the tolerant LA4133 are comprised of a higher protein expression associated with root growth against salt stress and induced carbohydrate metabolism (but lower than LA3465), which is coupled with ATP regeneration. The amino acid metabolism toward biosynthesis of organic osmolytes was strongly enhanced together with antioxidant enzymes. The two accessions showed different mechanisms in detoxification, fatty acid metabolism, and stress defenses. Chaperonins, signal transduction proteins, protein translation factors, and ribosomes also had differential expression in the two accessions. The salt-induced proteins and information on their responses to salt and dehydration stresses are described in Table 1. It is expected that the findings from this study will help prioritize the use of molecular markers for evaluating and improving traits controlled by the interaction of multiple genes such as tolerance to salt and/or water deficit stress.

\section{Literature Cited}

Andersen, G.R. and J. Nyborg. 2001. Structural studies of eukaryotic elongation factors. Cold Spring Harb. Symp. Quant. Biol. 66:425437.

Augustine, R.C., K.A. Pattavina, E. Tüzel, L. Vidali, and M. Bezanilla. 2011. Actin interacting protein 1 and actin depolymerizing factor drive rapid actin dynamics in Physcomitrella patens. Plant Cell 23:3696-3710.

Avsian-Kretchmer, O., Y. Gueta-Dahan, S. Lev-Yadun, R. Gollop, and G. Ben-Hayyim. 2004. The salt-stress signal transduction pathway that activates the gpx 1 promoter is mediated by intracellular $\mathrm{H}_{2} \mathrm{O}_{2}$, different from the pathway induced by extracellular $\mathrm{H}_{2} \mathrm{O}_{2}$. Plant Physiol. 135:1685-1696.

Barkla, B.J., R. Vera-Estrella, M. Maldonado-Gama, and O. Pantoja. 1999. Abscisic acid induction of vacuolar $\mathrm{H}^{+}$-ATPase activity in Mesembryanthemum crystallinum is developmentally regulated. Plant Physiol. 120:811-820.

Boehm, A.M., S. Pütz, D. Altenhöfer, A. Sickmann, and M. Falk. 2007. Precise protein quantification based on peptide quantification using iTRAQ $^{\mathrm{TM}}$. BMC Bioinformatics 8:214.

Bombarely, A., N. Menda, I.Y. Tecle, R.M. Buels, S. Strickler, T. Fischer-York, A. Pujar, J. Leto, J. Gosselin, and L.A. Mueller. 2011. The Sol Genomics Network (solgenomics.net): Growing tomatoes using Perl. Nucleic Acids Res. 39:D1149-D1155.

Cakir, B., A. Agasse, C. Gaillard, A. Saumonneau, S. Delrot, and R. Atanassova. 2003. A grape ASR protein involved in sugar and abscisic acid signaling. Plant Cell 15:2165-2180.

Conroy, C., J. Ching, Y. Gao, X. Wang, C. Rampitsch, and T. Xing. 2013. Knockout of AtMKK1 enhances salt tolerance and modifies metabolic activities in Arabidopsis. Plant Signal. Behav. 8:e24206.

Dannenfelser, R., N.R. Clark, and A. Ma'ayan. 2012. Genes2FANs: Connecting genes through functional association networks. BMC Bioinformatics 13:156.

Dit Frey, N.F., P. Muller, F. Jammes, D. Kizis, J. Leung, C. PerrotRechenmann, and M.W. Bianchi. 2010. The RNA binding protein Tudor-SN is essential for stress tolerance and stabilizes levels of stress-responsive mRNAs encoding secreted proteins in Arabidopsis. Plant Cell 22:1575-1591.

Durand, A., R. Hughes, A. Roussel, R. Flatman, B. Henrissat, and N. Juge. 2005. Emergence of a subfamily of xylanase inhibitors within glycoside hydrolase family 18. FEBS J. 272:1745-1755.

Ezin, V., R. de la Peña, and A. Ahanchede. 2010. Physiological and agronomical criteria for screening tomato genotypes for tolerance to salinity. Electronic J. Environ. Agr. Food Chem. 9:1641-1656.

Forsthoefel, N.R., D.M. Vernon, and J.C. Cushman. 1995. A salinityinduced gene from the halophyte $M$. crystallinum encodes a glycolytic 
enzyme, cofactor-independent phosphoglyceromutase. Plant Mol. Biol. 29:213-226.

Fowler, J.H., J. Narváez-Vásquez, D.N. Aromdee, V. Pautot, F.M. Holzer, and L.L. Walling. 2009. Leucine aminopeptidase regulates defense and wound signaling in tomato downstream of jasmonic acid. Plant Cell 21:1239-1251.

Franceschini, A., D. Szklarczyk, S. Frankild, M. Kuhn, M. Simonovic, A. Roth, J. Lin, P. Minguez, P. Bork, C. von Mering, and L.J. Jensen. 2013. STRING v9.1: Protein-protein interaction networks, with increased coverage and integration. Nucleic Acids Res. 41:D808D815.

Frary, A., D. Göl, D. Keleş, B. Okmen, H. Pinar, H.O. Siğva, A. Yemenicioğlu, and S. Doğanlar. 2010. Salt tolerance in Solanum pennellii: Antioxidant response and related QTL. BMC Plant Biol. 10:58.

Fu, J., I. Momčilović, and P.V. Vara Prasad. 2012. Roles of protein synthesis elongation factor EF-Tu in heat tolerance in plants. J. Bot. $835-836$.

Goldgur, Y., S. Rom, R. Ghirlando, D. Shkolnik, N. Shadrin, Z. Konrad, and D. Bar-Zvi. 2006. Desiccation and zinc binding induce transition of tomato abscisic acid stress ripening 1, a water stress- and salt stress-regulated plant-specific protein, from unfolded to folded state. Plant Physiol. 143:617-628.

González Besteiro, M.A. and R. Ulm. 2013. ATR and MKP1 play distinct roles in response to UV-B stress in Arabidopsis. Plant J. 73:1034-1043.

Gruber, J., S.Y. Tang, A.M. Jenner, I. Mudway, A. Blomberg, A. Behndig, K. Kasiman, C.Y. Lee, R.C. Seet, W. Zhang, C. Chen, F.J. Kelly, and B. Halliwell. 2009. Allantoin in human plasma, serum, and nasal-lining fluids as a biomarker of oxidative stress: Avoiding artifacts and establishing real in vivo concentrations. Antioxid. Redox Signal. 11:1767-1776.

Hoagland, D.R. and D.I. Arnon. 1950. The water-culture method for growing plants without soil. California Agr. Expt. Sta. Circ. 347.

Huang, Y.C., W.L. Huang, C.Y. Hong, H.S. Lur, and M.C. Chang. 2012. Comprehensive analysis of differentially expressed rice actin depolymerizing factor gene family and heterologous overexpression of OsADF3 confers Arabidopsis thaliana drought tolerance. Rice $5: 33$.

Jarsch, I.K. and T. Ott. 2011. Perspectives on remorin proteins, membrane rafts, and their role during plant-microbe interactions. Mol. Plant Microbe Interact. 24:7-12.

Johnson, K.L., B.J. Jones, A. Bacic, and C.J. Schultz. 2003. The fasciclin-like arabinogalactan proteins of Arabidopsis. A multigene family of putative cell adhesion molecules. Plant Physiol. 133:19111925.

Kalifa, Y., A. Gilad, Z. Konrad, M. Zaccai, P.A. Scolnik, and D. BarZvi. 2004. The water- and salt-stress-regulated Asrl (abscisic acid stress ripening) gene encodes a zinc-dependent DNA-binding protein. Biochem. J. 381:373-378.

Kim, J.Y., W.Y. Kim, K.J. Kwak, S.H. Oh, Y.S. Han, and H. Kang. 2010. Glycine-rich RNA-binding proteins are functionally conserved in Arabidopsis thaliana and Oryza sativa during cold adaptation process. J. Expt. Bot. 61:2317-2325.

Kim, S.H., D. Arnold, A. Lloyd, and S.J. Roux. 2001. Antisense expression of an Arabidopsis ran binding protein renders transgenic roots hypersensitive to auxin and alters auxin-induced root growth and development by arresting mitotic progress. Plant Cell 13:26192630.

Konishi, H., H. Yamane, M. Maeshima, and S. Komatsu. 2004. Characterization of fructose-bisphosphate aldolase regulated by gibberellin in roots of rice seedling. Plant Mol. Biol. 56:839-848.

Lackner, D.H., M.W. Schmidt, S. Wu, D.A. Wolf, and J. Bähler. 2012. Regulation of transcriptome, translation, and proteome in response to environmental stress in fission yeast. Genome Biol. 13:R25.

Lan, P. and W. Schmidt. 2011. The enigma of eIF5A in the iron deficiency response of Arabidopsis. Plant Signal. Behav. 6:528530 .
Lee, M.H., M.K. Min, Y.J. Lee, J.B. Jin, D.H. Shin, D.H. Kim, K.H. Lee, and I. Hwang. 2002. ADP-ribosylation factor 1 of Arabidopsis plays a critical role in intracellular trafficking and maintenance of endoplasmic reticulum morphology in Arabidopsis. Plant Physiol. 129:1507-1520.

Lemaire, K., R.F. Moura, M. Granvik, M. Igoillo-Esteve, H.E. Hohmeier, N. Hendrickx, C.B. Newgard, E. Waelkens, M. Cnop, and F. Schuit. 2011. Ubiquitin fold modifier 1 (UFM1) and its target UFBP1 protect pancreatic beta cells from ER stress-induced apoptosis. PLoS One 6:e18517.

Liebminger, E., S. Hüttner, U. Vavra, R. Fischl, J. Schoberer, J. Grass, C. Blaukopf, G.J. Seifert, F. Altmann, L. Mach, and R. Strasser. 2009. Class I alpha-mannosidases are required for N-glycan processing and root development in Arabidopsis thaliana. Plant Cell 21:3850-3867.

Lovelli, S., M. Perniola, T. Di Tommaso, R. Bochicchio, and M. Amato. 2012. Specific root length and diameter of hydroponicallygrown tomato plants under salinity. J. Agron. 11:101-106.

Luan, S. 1998. Protein phosphatases and signaling cascades in higher plants. Trends Plant Sci. 3:271-275.

Ma, S., Q. Gong, and H.J. Bohnert. 2006. Dissecting salt stress pathways. J. Expt. Bot. 57:1097-1107.

Maaroufi-Dguimi, H., M. Debouba, L. Gaufichon, G. Clément, H. Gouia, A. Hajjaji, and A. Suzuki. 2011. An Arabidopsis mutant disrupted in ASN2 encoding asparagine synthetase 2 exhibits low salt stress tolerance. Plant Physiol. Biochem. 49:623-628.

Maggio, A., G. Raimondi, A. Martino, and S. de Pascale. 2007. Salt stress response in tomato beyond the salinity tolerance threshold. Environ. Exp. Bot. 59:276-282.

Mahajan, S., G.K. Pandey, and N. Tuteja. 2008. Calcium- and saltstress signaling in plants: Shedding light on SOS pathway. Arch. Biochem. Biophys. 471:146-158.

Manaa, A., H. Ben Ahmed, B. Valot, J.P. Bouchet, S. Aschi-Smiti, M. Causse, and M. Faurobert. 2011. Salt and genotype impact on plant physiology and root proteome variations in tomato. J. Expt. Bot. 62:2797-2813.

Marjanović, M., R. Stikić, B. Vucelić-Radović, S. Savić, Z. Jovanović, N. Bertin, and M. Faurobert. 2012. Growth and proteomic analysis of tomato fruit under partial root-zone drying. OMICS 16:343-356.

Meier, I., T. Phelan, W. Gruissem, S. Spiker, and D. Schneider. 1996. MFP1, A novel plant filament-like protein with affinity for matrix attachment region DNA. Plant Cell 8:2105-2115.

Monks, D.E., K. Aghoram, P.D. Courtney, D.B. DeWald, and R.E. Dewey. 2001. Hyperosmotic stress induces the rapid phosphorylation of a soybean phosphatidylinositol transfer protein homolog through activation of the protein kinases SPK1 and SPK2. Plant Cell 3:1205-1219.

Nam, M.H., S.M. Huh, K.M. Kim, W.J. Park, J.B. Seo, K. Cho, D.Y. Kim, B.G. Kim, and I.S. Yoon. 2012. Comparative proteomic analysis of early salt stress-responsive proteins in roots of SnRK2 transgenic rice. Proteome Sci. 10:25.

Nesbitt, T.C. and S.D. Tanksley. 2002. Comparative sequencing in the genus Lycopersicon: Implications for the evolution of fruit size in the domestication of cultivated tomatoes. Genetics 162:365-379.

Omidbakhshfard, M.A., N. Omranian, F.S. Ahmadi, Z. Nikoloski, and B. Mueller-Roeber. 2012. Effect of salt stress on genes encoding translation-associated proteins in Arabidopsis thaliana. Plant Signal. Behav. 7:1095-1102.

Orino, K., L. Lehman, Y. Tsuji, H. Ayaki, S.V. Torti, and F.M. Torti. 2001. Ferritin and the response to oxidative stress. Biochem. J. 357:241-247.

Ortolan, T.G., P. Tongaonkar, D. Lambertson, L. Chen, C. Schauber, and $\mathrm{K}$. Madura. 2000. The DNA repair protein $\operatorname{rad} 23$ is a negative regulator of multi-ubiquitin chain assembly. Nat. Cell Biol. 2:601-608. Osakabe, Y., K. Yamaguchi-Shinozaki, K. Shinozaki, and L.S. Tran. 2013. Sensing the environment: Key roles of membrane-localized kinases in plant perception and response to abiotic stress. J. Expt. Bot. 64:445-458. 
País, S.M., M.T. Téllez-Iñón, and D.A. Capiati. 2009. Serine/threonine protein phosphatases type $2 \mathrm{~A}$ and their roles in stress signaling. Plant Signal. Behav. 4:1013-1015.

Panda, S.K. and M.H. Khan. 2009. Growth, oxidative damage and antioxidant responses in greengram (Vigna radiata L.) under shortterm salinity stress and its recovery. J. Agron. Crop Sci. 195:442454.

Pang, Q., S. Chen, S. Dai, Y. Chen, Y. Wang, and X. Yan. 2010. Comparative proteomics of salt tolerance in Arabidopsis thaliana and Thellungiella halophila. J. Proteome Res. 9:2584-2599.

Petricka, J.J., C.M. Winter, and P.N. Benfey. 2012. Control of Arabidopsis root development. Annu. Rev. Plant Biol. 63:563-590.

Pitzschke, A., A. Schikora, and H. Hirt. 2009. MAPK cascade signalling networks in plant defence. Curr. Opin. Plant Biol. 12: 421-426.

Qian, D., L. Jiang, L. Lu, C. Wei, and Y. Li. 2011. Biochemical and structural properties of cyanases from Arabidopsis thaliana and Oryza sativa. PLoS One 6:e18300.

Raffaele, S., E. Bayer, and S. Mongrand. 2009. Upregulation of the plant protein remorin correlates with dehiscence and cell maturation. A link with the maturation of plasmodesmata? Plant Signal. Behav. 4:915-919.

Ranc, N., S. Muños, J. Xu, M.C. Le Paslier, A. Chauveau, R. Bounon, S. Rolland, J.P. Bouchet, D. Brunel, and M. Causse. 2012. Genomewide association mapping in tomato (Solanum lycopersicum) is possible using genome admixture of Solanum lycopersicum var. cerasiforme. Genes Genomes Genet. 2:853-864.

Rasmussen, S., P. Barah, M.C. Suarez-Rodriguez, S. Bressendorff, P. Friis, P. Costantino, A.M. Bones, H.B. Nielsen, and J. Mundy. 2013 Transcriptome responses to combinations of stresses in Arabidopsis. Plant Physiol. 161:1783-1794.

Samaniego, R., S.Y. Jeong, I. Meier, and S.M. de la Espina. 2006. Dual location of MAR-binding, filament-like protein 1 in Arabidopsis, tobacco, and tomato. Planta 223:1201-1206.

Shalata, A. and M. Tal. 1998. The effect of salt stress on lipid peroxidation and antioxidants in the leaf of the cultivated tomato and its wild salt-tolerant relative Lycopersicon pennellii. Physiol. Plant. 104:169-174.

Shin, D., S.J. Moon, S.R. Park, B.G. Kim, and M.O. Byun. 2009. Elongation factor $1 \alpha$ from $A$. thaliana functions as molecular chaperone and confers resistance to salt stress in yeast and plants. Plant Sci. 177:156-160.

Tang, R.J., H. Liu, Y. Yang, L. Yang, X.S. Gao, V.J. Garcia, S. Luan, and H.X. Zhang. 2012. Tonoplast calcium sensors CBL2 and CBL3 control plant growth and ion homeostasis through regulating V-ATPase activity in Arabidopsis. Cell Res. 22:1650-1665.

Tilsner, J., K. Amari, and L. Torrance. 2011. Plasmodesmata viewed as specialised membrane adhesion sites. Protoplasma 248:39-60.

Thipyapong, P. and J.C. Steffens. 1997. Tomato polyphenol oxidase (differential response of the polyphenol oxidase $\mathrm{F}$ promoter to injuries and wound signals). Plant Physiol. 115:409-418.

Thipyapong, P., M.J. Stout, and J. Attajarusit. 2007. Functional analysis of polyphenol oxidases by antisense/sense technology. Molecules 12:1569-1595.

Tomato Genetics Resource Center. 2001. Accession details. LA4133. 20 Mar. 2013. <http://tgrc.ucdavis.edu/Data/Acc/ AccDetail.aspx?AccessionNum=LA4133>.

U.S. Department of Agriculture. 2013. Vegetables and pulses. 20 Apr. 2013. <http://www.ers.usda.gov/topics/crops/vegetables-pulses/ tomatoes.aspx\#.UXRDGLXvvzl>.
Vallabhaneni, H. and P.J. Farabaugh. 2009. Accuracy modulating mutations of the ribosomal protein S4-S5 interface do not necessarily destabilize the rps4-rps5 protein-protein interaction. RNA 15:11001109.

Wang, H., D. Liu, J. Sun, and A. Zhang. 2005. Asparagine synthetase gene TaASN1 from wheat is up-regulated by salt stress, osmotic stress and ABA. J. Plant Physiol. 162:81-89.

Wang, X., Y. Xu, Y. Han, S. Bao, J. Du, M. Yuan, Z. Xu, and K. Chong. 2006. Overexpression of RAN1 in rice and Arabidopsis alters primordial meristem, mitotic progress, and sensitivity to auxin. Plant Physiol. 140:91-101.

Wang, Y., F. Yang, M.A. Gritsenko, Y. Wang, T. Clauss, T. Liu, Y. Shen, M.E. Monroe, D. Lopez-Ferrer, T. Reno, R.J. Moore, R.L. Klemke, D.G. Camp, II, and R.D. Smith. 2011. Reversed-phase chromatography with multiple fraction concatenation strategy for proteome profiling of human MCF10A cells. Proteomics 11:20192026.

Wei, J. and E.C. Theil. 2000. Identification and characterization of the iron regulatory element in the ferritin gene of a plant (soybean). J. Biol. Chem. 275:17488-17493.

Wessel, D. and U.I. Fugge. 1984. A method for the quantitative recovery of protein in dilute solution in the presence of detergents and lipids. Anal. Biochem. 138:141-143.

West, G., D. Inzé, and G.T. Beemster. 2004. Cell cycle modulation in the response of the primary root of Arabidopsis to salt stress. Plant Physiol. 135:1050-1058.

Xi, L., K. Xu, Y. Qiao, S. Qu, Z. Zhang, and W. Dai. 2011. Differential expression of ferritin genes in response to abiotic stresses and hormones in pear (Pyrus pyrifolia). Mol. Biol. Rep. 38:44054413.

Xu, G.Y., P.S. Rocha, M.L. Wang, M.L. Xu, Y.C. Cui, L.Y. Li, Y.X. Zhu, and X. Xia. 2011. A novel rice calmodulin-like gene, OsMSR2, enhances drought and salt tolerance and increases ABA sensitivity in Arabidopsis. Planta 234:47-59.

Yang, W.Y., Y. Zheng, S.C. Bahn, X.Q. Pan, M.Y. Li, H.S. Vu, M.R. Roth, B. Scheu, R. Welti, Y.Y. Hong, and X.M. Wang. 2012. The patatin-containing phospholipase A pPLAII $\alpha$ modulates oxylipin formation and water loss in Arabidopsis thaliana. Mol. Plant 5:452460

Yang, Y., X. Qiang, K. Owsiany, S. Zhang, T.W. Thannhause, and L. Li. 2011. Evaluation of different multidimensional LC-MS/MS pipelines for iTRAQ-based proteomic analysis of potato tubers in response to cold storage. J. Proteome Res. 10:4647-4660.

Zhang, H., B. Han, T. Wang, S. Chen, H. Li, Y. Zhang, and S. Dai. 2012. Mechanisms of plant salt response: Insights from proteomics. J. Proteome Res. 11:49-67.

Zhou, S.P., M. Palmer, J. Zhou, S. Bhatti, K.J. Howe, T. Fish, and T.W. Thannhauser. 2013. Differential root proteome expression tomato genotypes with contrasting drought tolerance exposed to dehydration. J. Amer. Soc. Hort. Sci. 138:131-141.

Zhou, S.P., R.J. Sauvé, T. Fish, and T.W. Thannhauser. 2009. saltinduced and salt-suppressed proteins in tomato leaves. J. Amer. Soc. Hort. Sci. 134:289-294.

Zhou, S.P., R.J. Sauvé, Z. Liu, S. Reddy, S. Bhatti, S.D. Hucko, T. Fish, and T.W. Thannhauser. 2011. Identification of salt-induced changes in leaf and root proteomes of the wild tomato, Solanum chilense. J. Amer. Soc. Hort. Sci. 136:288-302.

Zuehlke, A. and J.L. Johnson. 2010. Hsp90 and co-chaperones twist the functions of diverse client proteins. Biopolymers 93:211217. 
Supplemental Table 2. Protein identification information of tomato 'Walter' accession LA3465 using the isobaric tags for relative and absolute quantitation (iTRAQ) analysis. ${ }^{\mathrm{z}}$

\begin{tabular}{|c|c|c|c|c|c|c|c|}
\hline Accession $^{\mathrm{y}}$ & $\begin{array}{l}\text { Protein } \\
\text { score }^{\mathrm{x}}\end{array}$ & $\begin{array}{c}\text { Total } \\
\text { matches (no.) }^{\mathrm{w}}\end{array}$ & $\begin{array}{c}\text { Unique } \\
\text { matches (no.) }\end{array}$ & $\begin{array}{c}\text { Total } \\
\text { sequences }(\text { no. })^{\mathrm{u}}\end{array}$ & $\begin{array}{c}\text { Unique } \\
\text { sequences }(\text { no. })^{t}\end{array}$ & $\begin{array}{c}\text { Protein } \\
\text { coverage }(\%)^{\mathrm{s}}\end{array}$ & $\begin{array}{c}\text { Highest } \\
\text { peptide score }\end{array}$ \\
\hline Solyc05g008460.2.1 & 1312 & 50 & 48 & 20 & 20 & 56.4 & 90.94 \\
\hline Solyc04g007550.2.1 & 1244 & 46 & 45 & 18 & 18 & 51.2 & 90.94 \\
\hline Solyc09g090140.2.1 & 1125 & 30 & 29 & 10 & 9 & 45.2 & 118.74 \\
\hline Solyc07g052510.2.1 & 1040 & 28 & 26 & 11 & 11 & 45.7 & 116.39 \\
\hline Solyc09g009020.2.1 & 939 & 31 & 28 & 16 & 15 & 61 & 90.76 \\
\hline Solyc07g062650.2.1 & 707 & 28 & 27 & 13 & 13 & 63.3 & 84.63 \\
\hline Solyc03g006700.2.1 & 592 & 21 & 18 & 8 & 8 & 32 & 107.08 \\
\hline Solyc04g012120.2.1 & 586 & 21 & 20 & 8 & 8 & 45.9 & 81.95 \\
\hline Solyc10g085550.1.1 & 583 & 18 & 17 & 10 & 9 & 37.6 & 85.34 \\
\hline Solyc08g080630.2.1 & 514 & 12 & 12 & 3 & 3 & 28.6 & 86.04 \\
\hline Solyc04g071890.2.1 & 506 & 13 & 13 & 7 & 7 & 35.3 & 115.46 \\
\hline Solyc06g009020.2.1 & 483 & 24 & 19 & 8 & 6 & 53.1 & 79.15 \\
\hline Solyc11g005330.1.1 & 465 & 17 & 16 & 10 & 10 & 37.4 & 93.64 \\
\hline Solyc01g111760.2.1 & 454 & 19 & 14 & 12 & 10 & 40.1 & 80.36 \\
\hline Solyc10g055670.1.1 & 449 & 19 & 14 & 12 & 10 & 40.1 & 80.36 \\
\hline Solyc12g099100.1.1 & 435 & 13 & 12 & 8 & 8 & 29.6 & 116.07 \\
\hline Solyc07g066600.2.1 & 429 & 18 & 17 & 11 & 11 & 42.9 & 78.39 \\
\hline Solyc01g102310.2.1 & 417 & 16 & 14 & 15 & 14 & 32.9 & 83.24 \\
\hline Solyc00g072400.2.1 & 411 & 15 & 13 & 9 & 9 & 44.2 & 86.96 \\
\hline Solyc01g106610.2.1 & 411 & 10 & 8 & 3 & 3 & 38.6 & 107.72 \\
\hline Solyc11g066060.1.1 & 410 & 20 & 15 & 13 & 11 & 25.8 & 74.83 \\
\hline Solyc09g010630.2.1 & 395 & 19 & 15 & 13 & 12 & 27.7 & 74.83 \\
\hline Solyc11g066390.1.1 & 390 & 8 & 8 & 4 & 4 & 39.6 & 127.94 \\
\hline Solyc05g053300.2.1 & 389 & 11 & 10 & 7 & 7 & 25.8 & 101.84 \\
\hline Solyc10g055800.1.1 & 374 & 12 & 12 & 5 & 5 & 29.5 & 87.98 \\
\hline Solyc01g059980.2.1 & 366 & 15 & 14 & 8 & 8 & 42.5 & 64.83 \\
\hline Solyc05g014470.2.1 & 363 & 18 & 12 & 9 & 6 & 43.5 & 94.15 \\
\hline Solyc09g082060.2.1 & 361 & 13 & 11 & 7 & 6 & 40.6 & 80.97 \\
\hline Solyc08g074680.2.1 & 358 & 10 & 9 & 8 & 7 & 6.9 & 80.74 \\
\hline Solyc02g086880.2.1 & 353 & 11 & 10 & 7 & 7 & 27.3 & 142.2 \\
\hline Solyc11g067100.1.1 & 350 & 13 & 8 & 7 & 6 & 77 & 97.11 \\
\hline Solyc10g083570.1.1 & 344 & 14 & 13 & 9 & 9 & 39.4 & 70.52 \\
\hline Solyc11g010200.1.1 & 342 & 13 & 12 & 6 & 5 & 30.1 & 78.85 \\
\hline Solyc06g073190.2.1 & 332 & 14 & 12 & 11 & 9 & 47.3 & 69.52 \\
\hline Solyc10g081510.1.1 & 329 & 16 & 12 & 11 & 10 & 20.7 & 71.76 \\
\hline Solyc01g105070.2.1 & 323 & 7 & 7 & 7 & 7 & 39.5 & 104.72 \\
\hline Solyc10g055810.1.1 & 320 & 11 & 11 & 5 & 5 & 31.7 & 87.98 \\
\hline Solyc09g009260.2.1 & 317 & 15 & 12 & 9 & 8 & 35.2 & 74.2 \\
\hline Solyc07g051850.2.1 & 314 & 8 & 8 & 6 & 6 & 21.3 & 85.65 \\
\hline Solyc04g077020.2.1 & 304 & 10 & 9 & 8 & 8 & 29.1 & 112.29 \\
\hline Solyc09g008280.1.1 & 300 & 13 & 11 & 7 & 7 & 31.5 & 71.96 \\
\hline Solyc12g010040.1.1 & 298 & 9 & 8 & 6 & 6 & 19.2 & 77.95 \\
\hline Solyc11g069720.1.1 & 297 & 13 & 9 & 11 & 7 & 22 & 89.76 \\
\hline Solyc04g074510.2.1 & 296 & 12 & 12 & 4 & 4 & 22.8 & 79.18 \\
\hline Solyc00g009020.2.1 & 294 & 11 & 10 & 8 & 7 & 33.1 & 78.46 \\
\hline Solyc07g043320.2.1 & 292 & 11 & 8 & 10 & 7 & 11.3 & 82.95 \\
\hline Solyc09g009390.2.1 & 289 & 16 & 14 & 12 & 10 & 40 & 59.44 \\
\hline Solyc09g090980.2.1 & 288 & 18 & 11 & 8 & 6 & 72.5 & 61.02 \\
\hline Solyc10g086100.1.1 & 285 & 9 & 8 & 4 & 3 & 36.2 & 80.03 \\
\hline Solyc11g039980.1.1 & 283 & 7 & 7 & 4 & 4 & 38.4 & 84.79 \\
\hline Solyc02g084790.2.1 & 282 & 9 & 8 & 7 & 6 & 33.4 & 97.95 \\
\hline Solyc01g100380.2.1 & 282 & 11 & 11 & 6 & 6 & 24.2 & 82.76 \\
\hline Solyc08g016510.2.1 & 279 & 6 & 6 & 5 & 5 & 36.3 & 102.65 \\
\hline Solyc06g035970.2.1 & 278 & 11 & 11 & 7 & 7 & 20.6 & 79.15 \\
\hline Solyc12g088670.1.1 & 274 & 10 & 9 & 7 & 6 & 23.6 & 99.7 \\
\hline Solyc06g076640.2.1 & 274 & 11 & 11 & 7 & 7 & 20.8 & 79.15 \\
\hline
\end{tabular}


Supplemental Table 2. Continued.

\begin{tabular}{|c|c|c|c|c|c|c|c|}
\hline Accession $^{y}$ & $\begin{array}{l}\text { Protein } \\
\text { score }^{\mathrm{x}}\end{array}$ & $\begin{array}{c}\text { Total } \\
\text { matches (no.) }\end{array}$ & $\begin{array}{c}\text { Unique } \\
\text { matches (no.) }\end{array}$ & $\begin{array}{c}\text { Total } \\
\text { sequences (no.) })^{\mathrm{u}}\end{array}$ & $\begin{array}{c}\text { Unique } \\
\text { sequences (no.) }\end{array}$ & $\begin{array}{c}\text { Protein } \\
\text { coverage }(\%)^{\mathrm{s}}\end{array}$ & $\begin{array}{c}\text { Highest } \\
\text { peptide score }\end{array}$ \\
\hline $\begin{array}{l}\text { Solyc09g092380.2.1 } \\
\end{array}$ & 273 & 13 & 11 & 9 & 7 & 32.8 & 69.76 \\
\hline Solyc02g067460.2.1 & 273 & 8 & 8 & 5 & 5 & 27.2 & 73.35 \\
\hline Solyc11g010470.1.1 & 273 & 9 & 9 & 4 & 4 & 24.1 & 79.65 \\
\hline Solyc02g070510.2.1 & 270 & 6 & 6 & 5 & 5 & 36.3 & 102.65 \\
\hline Solyc08g079930.1.1 & 269 & 8 & 8 & 7 & 7 & 15.7 & 73.8 \\
\hline Solyc10g076220.1.1 & 268 & 11 & 9 & 6 & 6 & 27.6 & 87.8 \\
\hline Solyc06g071100.2.1 & 268 & 8 & 7 & 6 & 6 & 11.2 & 75.05 \\
\hline Solyc08g062920.2.1 & 267 & 10 & 9 & 9 & 8 & 18 & 83.52 \\
\hline Solyc03g113400.2.1 & 267 & 8 & 7 & 6 & 6 & 10.9 & 75.05 \\
\hline Solyc04g011510.2.1 & 263 & 12 & 11 & 7 & 7 & 42.5 & 70.33 \\
\hline Solyc12g005860.1.1 & 263 & 9 & 8 & 9 & 8 & 14.1 & 82.52 \\
\hline Solyc12g055800.1.1 & 260 & 9 & 9 & 7 & 7 & 19.3 & 102.19 \\
\hline Solyc12g057110.2.1 & 257 & 11 & 10 & 6 & 5 & 37.4 & 79.18 \\
\hline Solyc02g063070.2.1 & 257 & 11 & 10 & 6 & 5 & 33.8 & 87.23 \\
\hline Solyc05g053470.2.1 & 257 & 12 & 12 & 10 & 10 & 26.4 & 68.33 \\
\hline Solyc04g049450.2.1 & 255 & 10 & 10 & 7 & 7 & 17.9 & 69.95 \\
\hline Solyc10g055820.1.1 & 254 & 9 & 8 & 5 & 5 & 31.7 & 87.98 \\
\hline Solyc10g085020.1.1 & 249 & 11 & 11 & 8 & 8 & 23.8 & 83.77 \\
\hline Solyc07g006650.2.1 & 247 & 6 & 5 & 4 & 3 & 15.6 & 90.27 \\
\hline Solyc07g053260.2.1 & 246 & 9 & 9 & 5 & 5 & 28.7 & 73.73 \\
\hline Solyc04g055170.2.1 & 246 & 10 & 10 & 7 & 7 & 23.1 & 87.85 \\
\hline Solyc $10 \mathrm{~g} 078550.1 .1$ & 244 & 10 & 9 & 9 & 8 & 34.5 & 69.15 \\
\hline Solyc01g099760.2.1 & 244 & 10 & 9 & 8 & 7 & 33.3 & 68.78 \\
\hline Solyc11g005640.1.1 & 244 & 12 & 11 & 2 & 2 & 14.4 & 57.28 \\
\hline Solyc04g049330.2.1 & 243 & 7 & 7 & 4 & 4 & 46.8 & 100.47 \\
\hline Solyc07g042550.2.1 & 242 & 12 & 10 & 11 & 10 & 21.1 & 79.82 \\
\hline Solyc08g082820.2.1 & 242 & 11 & 9 & 10 & 8 & 21 & 75.87 \\
\hline Solyc02g080210.2.1 & 241 & 10 & 9 & 5 & 4 & 13.6 & 55.78 \\
\hline Solyc05g008600.2.1 & 237 & 10 & 8 & 5 & 5 & 23.5 & 74.77 \\
\hline Solyc03g082920.2.1 & 236 & 10 & 9 & 9 & 8 & 19.6 & 70.29 \\
\hline Solyc07g045440.1.1 & 235 & 9 & 7 & 6 & 5 & 29.1 & 71.03 \\
\hline Solyc02g084800.2.1 & 234 & 7 & 6 & 6 & 6 & 34.8 & 79.88 \\
\hline Solyc04g054980.2.1 & 234 & 7 & 7 & 4 & 4 & 30.3 & 78.55 \\
\hline Solyc09g007520.2.1 & 234 & 6 & 5 & 5 & 5 & 29 & 91.52 \\
\hline Solyc02g084780.2.1 & 232 & 8 & 6 & 7 & 6 & 31.6 & 79.88 \\
\hline Solyc04g081490.2.1 & 230 & 11 & 11 & 8 & 8 & 23.3 & 83.77 \\
\hline Solyc08g006860.2.1 & 228 & 10 & 8 & 5 & 4 & 19.6 & 101.75 \\
\hline Solyc09g090990.2.1 & 227 & 13 & 9 & 8 & 6 & 66.9 & 60.76 \\
\hline Solyc01g103450.2.1 & 227 & 7 & 7 & 6 & 6 & 15.9 & 66.37 \\
\hline Solyc06g005160.2.1 & 225 & 10 & 6 & 7 & 4 & 53.2 & 86.87 \\
\hline Solyc11g011960.1.1 & 225 & 8 & 6 & 7 & 6 & 22.2 & 115.45 \\
\hline Solyc12g095960.1.1 & 223 & 9 & 7 & 5 & 4 & 28.5 & 109.62 \\
\hline Solyc08g062660.2.1 & 222 & 7 & 6 & 5 & 4 & 35.3 & 70.54 \\
\hline Solyc03g115990.1.1 & 222 & 7 & 7 & 7 & 7 & 27.2 & 78.26 \\
\hline Solyc01g101060.2.1 & 222 & 11 & 10 & 5 & 5 & 26 & 71.45 \\
\hline Solyc06g060290.2.1 & 222 & 8 & 6 & 5 & 4 & 18.7 & 63.35 \\
\hline Solyc09g073000.2.1 & 221 & 10 & 9 & 6 & 5 & 21.8 & 70.82 \\
\hline Solyc04g076060.2.1 & 217 & 9 & 9 & 5 & 5 & 30.2 & 79.65 \\
\hline Solyc01g056940.2.1 & 215 & 10 & 8 & 3 & 2 & 28.2 & 57.28 \\
\hline Solyc01g111120.2.1 & 211 & 9 & 7 & 6 & 4 & 29.4 & 55.81 \\
\hline Solyc12g015880.1.1 & 210 & 13 & 9 & 12 & 8 & 24 & 69.26 \\
\hline Solyc04g073990.2.1 & 210 & 10 & 9 & 7 & 7 & 23.9 & 59.09 \\
\hline Solyc06g083620.2.1 & 207 & 5 & 5 & 5 & 5 & 20 & 78.67 \\
\hline Solyc10g086190.1.1 & 206 & 7 & 7 & 6 & 6 & 32.2 & 81.36 \\
\hline Solyc06g073310.2.1 & 206 & 6 & 6 & 3 & 3 & 25.3 & 66.18 \\
\hline Solyc10g083970.1.1 & 204 & 8 & 7 & 5 & 5 & 19.7 & 71.74 \\
\hline Solyc11g072190.1.1 & 202 & 8 & 6 & 5 & 5 & 40.5 & 83.82 \\
\hline
\end{tabular}


Supplemental Table 2. Continued.

\begin{tabular}{|c|c|c|c|c|c|c|c|}
\hline Accession $^{y}$ & $\begin{array}{l}\text { Protein } \\
\text { score }^{\mathrm{x}}\end{array}$ & $\begin{array}{c}\text { Total } \\
\text { matches (no.) }{ }^{\mathrm{w}}\end{array}$ & $\begin{array}{c}\text { Unique } \\
\text { matches (no.) }\end{array}$ & $\begin{array}{c}\text { Total } \\
\text { sequences }(\text { no. })^{\mathrm{u}}\end{array}$ & $\begin{array}{c}\text { Unique } \\
\text { sequences (no.) }\end{array}$ & $\begin{array}{c}\text { Protein } \\
\text { coverage }(\%)^{\mathrm{s}}\end{array}$ & $\begin{array}{c}\text { Highest } \\
\text { peptide score }\end{array}$ \\
\hline Solyc11g042930.1.1 & 202 & 5 & 5 & 3 & 3 & 35.5 & 86.23 \\
\hline Solyc03g019780.2.1 & 202 & 7 & 6 & 3 & 3 & 17.1 & 63.38 \\
\hline Solyc03g114500.2.1 & 202 & 5 & 4 & 5 & 4 & 17 & 85.27 \\
\hline Solyc06g071920.2.1 & 200 & 6 & 6 & 5 & 5 & 25.2 & 97.02 \\
\hline Solyc03g111200.2.1 & 199 & 8 & 8 & 5 & 5 & 23.4 & 83.11 \\
\hline Solyc05g054580.2.1 & 198 & 7 & 6 & 4 & 4 & 19.9 & 91.74 \\
\hline Solyc01g091530.2.1 & 196 & 6 & 6 & 4 & 4 & 14.5 & 73.89 \\
\hline Solyc01g111300.2.1 & 195 & 6 & 4 & 4 & 4 & 36.1 & 85.91 \\
\hline Solyc06g059740.2.1 & 194 & 7 & 5 & 7 & 5 & 28.1 & 95.11 \\
\hline Solyc07g044840.2.1 & 194 & 7 & 5 & 6 & 4 & 18.2 & 83.79 \\
\hline Solyc07g064130.1.1 & 193 & 10 & 8 & 3 & 2 & 8.3 & 57.28 \\
\hline Solyc12g096700.1.1 & 192 & 7 & 6 & 4 & 3 & 29.4 & 66.18 \\
\hline Solyc07g052540.2.1 & 192 & 5 & 4 & 4 & 3 & 19.1 & 127.12 \\
\hline Solyc04g079180.2.1 & 190 & 5 & 5 & 4 & 4 & 24.2 & 81.91 \\
\hline Solyc07g065120.2.1 & 189 & 5 & 5 & 5 & 5 & 11.8 & 65.15 \\
\hline Solyc08g080670.1.1 & 188 & 9 & 8 & 3 & 3 & 18.8 & 54.72 \\
\hline Solyc07g065840.2.1 & 187 & 11 & 9 & 10 & 8 & 19.6 & 69.26 \\
\hline Solyc07g017780.2.1 & 187 & 8 & 6 & 7 & 6 & 12.6 & 66.18 \\
\hline Solyc07g020860.2.1 & 186 & 8 & 8 & 5 & 5 & 37 & 57.82 \\
\hline Solyc08g081530.2.1 & 186 & 5 & 5 & 5 & 5 & 17 & 94.5 \\
\hline Solyc06g068860.2.1 & 185 & 4 & 4 & 4 & 4 & 5.7 & 93.96 \\
\hline Solyc10g008140.2.1 & 184 & 4 & 4 & 4 & 4 & 26 & 88.62 \\
\hline Solyc12g043110.1.1 & 182 & 8 & 8 & 8 & 8 & 14.9 & 65.67 \\
\hline Solyc12g042650.1.1 & 179 & 6 & 6 & 4 & 4 & 44.7 & 70.06 \\
\hline Solyc12g056120.1.1 & 179 & 5 & 4 & 5 & 4 & 20.6 & 85.65 \\
\hline Solyc04g082200.2.1 & 178 & 7 & 6 & 6 & 5 & 30.6 & 67.19 \\
\hline Solyc10g078620.1.1 & 178 & 9 & 8 & 4 & 3 & 18.1 & 53.59 \\
\hline Solyc08g079920.1.1 & 177 & 5 & 5 & 5 & 5 & 12.9 & 62.08 \\
\hline Solyc01g111450.2.1 & 176 & 6 & 4 & 4 & 3 & 21.7 & 79.19 \\
\hline Solyc08g080680.2.1 & 175 & 4 & 4 & 2 & 2 & 25.5 & 72.11 \\
\hline Solyc05g046010.2.1 & 174 & 9 & 8 & 5 & 5 & 22.3 & 66.78 \\
\hline Solyc03g058920.2.1 & 174 & 4 & 4 & 4 & 4 & 14.8 & 90.32 \\
\hline Solyc06g082630.2.1 & 174 & 4 & 4 & 3 & 3 & 12.1 & 98.67 \\
\hline Solyc07g052530.2.1 & 173 & 5 & 4 & 4 & 3 & 19.1 & 127.12 \\
\hline Solyc01g106620.2.1 & 172 & 6 & 6 & 2 & 2 & 21.2 & 77.26 \\
\hline Solyc00g323130.2.1 & 170 & 8 & 8 & 5 & 5 & 34.8 & 62.03 \\
\hline Solyc01g009020.2.1 & 169 & 3 & 3 & 2 & 2 & 31.9 & 75.03 \\
\hline Solyc04g011500.2.1 & 169 & 7 & 6 & 5 & 5 & 22.5 & 75.59 \\
\hline Solyc07g066610.2.1 & 169 & 7 & 6 & 5 & 4 & 17.4 & 76.14 \\
\hline Solyc12g094620.1.1 & 168 & 6 & 6 & 5 & 5 & 19.1 & 51.57 \\
\hline Solyc10g050160.1.1 & 167 & 4 & 4 & 3 & 3 & 19.2 & 105.11 \\
\hline Solyc06g075180.1.1 & 165 & 6 & 6 & 4 & 4 & 35.5 & 45.37 \\
\hline Solyc05g046020.2.1 & 165 & 9 & 8 & 4 & 4 & 15.6 & 66.78 \\
\hline Solyc07g052350.2.1 & 165 & 6 & 6 & 6 & 6 & 8.9 & 85.21 \\
\hline Solyc10g084050.1.1 & 164 & 9 & 6 & 9 & 6 & 16 & 89.76 \\
\hline Solyc00g006800.2.1 & 164 & 5 & 5 & 5 & 5 & 15.8 & 64.86 \\
\hline Solyc01g106210.2.1 & 163 & 8 & 5 & 7 & 5 & 14.5 & 82.04 \\
\hline Solyc01g100320.2.1 & 162 & 9 & 6 & 7 & 4 & 29.5 & 46.09 \\
\hline Solyc10g006650.2.1 & 162 & 4 & 3 & 3 & 2 & 24.6 & 90.39 \\
\hline Solyc05g012480.2.1 & 161 & 3 & 3 & 2 & 2 & 6.8 & 75.41 \\
\hline Solyc01g008950.2.1 & 160 & 5 & 4 & 3 & 3 & 33.6 & 67.74 \\
\hline Solyc01g104170.2.1 & 159 & 5 & 5 & 3 & 3 & 19.2 & 76.03 \\
\hline Solyc10g007290.2.1 & 158 & 9 & 7 & 8 & 7 & 13 & 67.61 \\
\hline Solyc10g080500.1.1 & 157 & 7 & 6 & 5 & 5 & 22.5 & 75.59 \\
\hline Solyc09g057670.2.1 & 155 & 7 & 6 & 4 & 4 & 40.3 & 46.88 \\
\hline Solyc01g089970.2.1 & 155 & 6 & 5 & 5 & 4 & 32.4 & 69.04 \\
\hline Solyc10g083650.1.1 & 155 & 3 & 3 & 3 & 3 & 25.4 & 89.25 \\
\hline
\end{tabular}


Supplemental Table 2. Continued.

\begin{tabular}{|c|c|c|c|c|c|c|c|}
\hline Accession $^{y}$ & $\begin{array}{l}\text { Protein } \\
\text { score }^{\mathrm{x}}\end{array}$ & $\begin{array}{c}\text { Total } \\
\text { matches (no.) }\end{array}$ & $\begin{array}{c}\text { Unique } \\
\text { matches (no.) }^{\mathrm{v}}\end{array}$ & $\begin{array}{c}\text { Total } \\
\text { sequences }(\text { no. })^{\mathrm{u}}\end{array}$ & $\begin{array}{c}\text { Unique } \\
\text { sequences (no.) }^{\mathrm{t}}\end{array}$ & $\begin{array}{c}\text { Protein } \\
\text { coverage }(\%)^{\mathrm{s}}\end{array}$ & $\begin{array}{c}\text { Highest } \\
\text { peptide score }\end{array}$ \\
\hline$\overline{\text { Solyc02g082000.2.1 }}$ & 155 & 4 & 4 & 2 & 2 & 23.8 & 62.98 \\
\hline Solyc01g067740.2.1 & 155 & 5 & 5 & 3 & 3 & 23.7 & 60.31 \\
\hline Solyc04g008740.2.1 & 155 & 6 & 6 & 6 & 6 & 18.8 & 61.33 \\
\hline Solyc11g069790.1.1 & 155 & 6 & 5 & 6 & 5 & 15.1 & 78.54 \\
\hline Solyc07g008130.2.1 & 155 & 3 & 3 & 1 & 1 & 11.2 & 81.1 \\
\hline Solyc06g005940.2.1 & 154 & 9 & 7 & 7 & 5 & 17.2 & 42.91 \\
\hline Solyc04g077970.2.1 & 154 & 4 & 4 & 3 & 3 & 16.2 & 80.56 \\
\hline Solyc01g111170.2.1 & 153 & 14 & 10 & 7 & 6 & 50.9 & 38.26 \\
\hline Solyc03g114150.2.1 & 152 & 4 & 4 & 4 & 4 & 12.1 & 86.9 \\
\hline Solyc01g005250.2.1 & 151 & 2 & 2 & 2 & 2 & 10.2 & 102.99 \\
\hline Solyc02g062510.2.1 & 149 & 3 & 2 & 3 & 2 & 13.9 & 89.24 \\
\hline Solyc04g080850.2.1 & 148 & 7 & 6 & 4 & 4 & 35.8 & 58.12 \\
\hline Solyc04g005340.2.1 & 148 & 7 & 7 & 7 & 7 & 31.7 & 52.37 \\
\hline Solyc09g091840.2.1 & 146 & 5 & 5 & 5 & 5 & 15.6 & 62.13 \\
\hline Solyc11g011380.1.1 & 145 & 7 & 5 & 6 & 5 & 35.3 & 71.19 \\
\hline Solyc07g042250.2.1 & 145 & 7 & 5 & 6 & 5 & 31.2 & 78.21 \\
\hline Solyc09g090430.2.1 & 145 & 2 & 2 & 2 & 2 & 26.3 & 112.32 \\
\hline Solyc01g010760.2.1 & 145 & 6 & 5 & 5 & 4 & 19.9 & 57.66 \\
\hline Solyc12g010860.1.1 & 144 & 3 & 3 & 3 & 3 & 17.6 & 92.36 \\
\hline Solyc03g115110.2.1 & 143 & 4 & 4 & 3 & 3 & 16.7 & 68.89 \\
\hline Solyc01g106260.2.1 & 143 & 7 & 5 & 7 & 5 & 15.4 & 62.23 \\
\hline Solyc09g090700.1.1 & 143 & 3 & 3 & 3 & 3 & 13 & 79.72 \\
\hline Solyc12g088720.1.1 & 143 & 5 & 4 & 5 & 4 & 12 & 63.54 \\
\hline Solyc08g079260.2.1 & 141 & 9 & 7 & 9 & 7 & 20.6 & 39.54 \\
\hline Solyc09g072700.2.1 & 140 & 7 & 5 & 5 & 4 & 24.5 & 90.37 \\
\hline Solyc06g074430.2.1 & 139 & 6 & 3 & 4 & 2 & 45.8 & 80.17 \\
\hline Solyc01g099770.2.1 & 139 & 7 & 6 & 5 & 4 & 36.3 & 42.09 \\
\hline Solyc10g076240.1.1 & 139 & 7 & 6 & 6 & 6 & 25.2 & 62.74 \\
\hline Solyc09g007940.2.1 & 139 & 4 & 4 & 3 & 3 & 18.5 & 81.36 \\
\hline Solyc09g092430.2.1 & 139 & 4 & 2 & 4 & 2 & 14.5 & 110.89 \\
\hline Solyc02g038690.1.1 & 137 & 6 & 6 & 1 & 1 & 11.2 & 50.81 \\
\hline Solyc10g005100.2.1 & 136 & 6 & 5 & 3 & 3 & 31.8 & 49.93 \\
\hline Solyc10g005510.2.1 & 136 & 4 & 3 & 4 & 3 & 16.9 & 57.79 \\
\hline Solyc04g081570.2.1 & 136 & 7 & 6 & 7 & 6 & 11.5 & 51.47 \\
\hline Solyc12g009140.1.1 & 136 & 3 & 3 & 2 & 2 & 7.3 & 62.81 \\
\hline Solyc11g070050.1.1 & 135 & 4 & 4 & 4 & 4 & 42.2 & 74.16 \\
\hline Solyc07g041310.2.1 & 135 & 6 & 6 & 5 & 5 & 23.8 & 80.47 \\
\hline Solyc12g014180.1.1 & 135 & 5 & 5 & 4 & 4 & 16.7 & 75.72 \\
\hline Solyc10g078690.1.1 & 134 & 2 & 2 & 2 & 2 & 22.6 & 105.8 \\
\hline Solyc01g080010.2.1 & 134 & 6 & 5 & 5 & 4 & 17.8 & 57.9 \\
\hline Solyc01g110120.2.1 & 134 & 4 & 4 & 4 & 4 & 7.7 & 67.42 \\
\hline Solyc06g069090.2.1 & 133 & 6 & 5 & 4 & 3 & 35.1 & 94.58 \\
\hline Solyc01g102380.2.1 & 133 & 7 & 6 & 2 & 2 & 12.5 & 49.89 \\
\hline Solyc04g014510.2.1 & 132 & 8 & 6 & 6 & 4 & 36 & 50.4 \\
\hline Solyc05g014980.2.1 & 132 & 7 & 6 & 4 & 3 & 23.6 & 60.96 \\
\hline Solyc01g005560.2.1 & 132 & 6 & 4 & 5 & 4 & 17.1 & 62.21 \\
\hline Solyc06g072580.2.1 & 132 & 5 & 4 & 4 & 3 & 14.7 & 64.95 \\
\hline Solyc02g079500.2.1 & 132 & 6 & 5 & 3 & 3 & 9.3 & 48.74 \\
\hline Solyc06g005260.2.1 & 131 & 4 & 3 & 4 & 3 & 46.3 & 74.92 \\
\hline Solyc06g076660.2.1 & 131 & 3 & 3 & 3 & 3 & 23.1 & 77.23 \\
\hline Solyc10g078150.1.1 & 131 & 6 & 6 & 3 & 3 & 22.2 & 62.45 \\
\hline Solyc01g090750.2.1 & 131 & 3 & 3 & 2 & 2 & 5.9 & 69.97 \\
\hline Solyc06g005150.2.1 & 130 & 8 & 4 & 6 & 3 & 43.6 & 63.85 \\
\hline Solyc02g084920.2.1 & 128 & 4 & 3 & 4 & 3 & 38.1 & 54.53 \\
\hline Solyc12g014210.1.1 & 128 & 2 & 2 & 2 & 2 & 11.3 & 77.32 \\
\hline Solyc05g009980.2.1 & 128 & 3 & 3 & 3 & 3 & 8.2 & 68.86 \\
\hline Solyc05g053810.2.1 & 127 & 7 & 5 & 5 & 3 & 13.4 & 56.73 \\
\hline
\end{tabular}


Supplemental Table 2. Continued.

\begin{tabular}{|c|c|c|c|c|c|c|c|}
\hline Accession $^{y}$ & $\begin{array}{l}\text { Protein } \\
\text { score }^{\mathrm{x}}\end{array}$ & $\begin{array}{c}\text { Total } \\
\text { matches (no.) }\end{array}$ & $\begin{array}{c}\text { Unique } \\
\text { matches (no.) }\end{array}$ & $\begin{array}{c}\text { Total } \\
\text { sequences }(\text { no. })^{\mathrm{u}}\end{array}$ & $\begin{array}{c}\text { Unique } \\
\text { sequences (no.) }\end{array}$ & $\begin{array}{c}\text { Protein } \\
\text { coverage }(\%)^{\mathrm{s}}\end{array}$ & $\begin{array}{c}\text { Highest } \\
\text { peptide score }\end{array}$ \\
\hline Solyc06g005060.2.1 & 126 & 9 & 7 & 6 & 6 & 20.3 & 36.13 \\
\hline Solyc07g053280.2.1 & 126 & 2 & 2 & 2 & 2 & 6.2 & 96.03 \\
\hline Solyc06g083790.2.1 & 125 & 7 & 6 & 5 & 5 & 18.3 & 48.82 \\
\hline Solyc04g078540.2.1 & 125 & 3 & 3 & 3 & 3 & 10.4 & 74.06 \\
\hline Solyc01g100370.2.1 & 124 & 2 & 2 & 2 & 2 & 20.5 & 103.14 \\
\hline Solyc01g107910.2.1 & 124 & 2 & 2 & 2 & 2 & 14.1 & 105.11 \\
\hline Solyc08g062800.2.1 & 123 & 7 & 5 & 6 & 4 & 19.6 & 47.18 \\
\hline Solyc09g090520.2.1 & 123 & 7 & 6 & 6 & 6 & 18.3 & 53.41 \\
\hline Solyc06g060790.1.1 & 123 & 2 & 2 & 2 & 2 & 14.5 & 94.93 \\
\hline Solyc10g005960.1.1 & 123 & 3 & 3 & 3 & 3 & 12.5 & 89.88 \\
\hline Solyc07g043420.2.1 & 122 & 4 & 3 & 4 & 3 & 18.4 & 80.06 \\
\hline Solyc01g028810.2.1 & 122 & 7 & 7 & 6 & 6 & 16 & 51.35 \\
\hline Solyc05g054090.2.1 & 121 & 4 & 4 & 4 & 4 & 52.1 & 62.45 \\
\hline Solyc03g111010.2.1 & 121 & 8 & 5 & 4 & 3 & 16.9 & 47.65 \\
\hline Solyc00g071180.2.1 & 121 & 4 & 4 & 3 & 3 & 15.4 & 60.79 \\
\hline Solyc02g093230.2.1 & 121 & 2 & 2 & 2 & 2 & 14.9 & 105.11 \\
\hline Solyc03g097070.2.1 & 121 & 3 & 3 & 3 & 3 & 12.9 & 95.71 \\
\hline Solyc03g096540.2.1 & 120 & 5 & 4 & 3 & 3 & 22.3 & 70.89 \\
\hline Solyc07g045240.2.1 & 120 & 3 & 3 & 3 & 3 & 17.2 & 89.7 \\
\hline Solyc01g107870.2.1 & 120 & 5 & 4 & 5 & 4 & 14 & 58.75 \\
\hline Solyc01g006300.2.1 & 120 & 2 & 2 & 2 & 2 & 11.1 & 84.65 \\
\hline Solyc04g005160.1.1 & 120 & 4 & 4 & 3 & 3 & 8.7 & 58.15 \\
\hline Solyc01g103800.2.1 & 119 & 4 & 4 & 3 & 3 & 32.2 & 63.34 \\
\hline Solyc06g007610.2.1 & 119 & 3 & 3 & 2 & 2 & 23 & 65.62 \\
\hline Solyc12g099000.1.1 & 119 & 8 & 7 & 4 & 4 & 20.6 & 45.13 \\
\hline Solyc04g080570.2.1 & 118 & 3 & 2 & 3 & 2 & 22.3 & 93.77 \\
\hline Solyc08g079020.2.1 & 118 & 2 & 2 & 2 & 2 & 20.9 & 85.78 \\
\hline Solyc05g018570.2.1 & 118 & 4 & 4 & 4 & 4 & 15.6 & 58.49 \\
\hline Solyc08g067020.2.1 & 117 & 7 & 5 & 4 & 3 & 42.3 & 46.83 \\
\hline Solyc08g008210.2.1 & 117 & 5 & 5 & 4 & 4 & 20.7 & 55.19 \\
\hline Solyc12g095760.1.1 & 117 & 3 & 3 & 2 & 2 & 5.3 & 55.72 \\
\hline Solyc11g006070.1.1 & 116 & 3 & 3 & 2 & 2 & 21.6 & 68.3 \\
\hline Solyc02g092440.2.1 & 116 & 3 & 3 & 2 & 2 & 14.1 & 66.52 \\
\hline Solyc08g079170.2.1 & 116 & 5 & 3 & 5 & 3 & 11.4 & 62 \\
\hline Solyc12g056250.1.1 & 115 & 4 & 4 & 4 & 4 & 29.2 & 55.8 \\
\hline Solyc04g081440.2.1 & 115 & 2 & 2 & 2 & 2 & 6.3 & 74.44 \\
\hline Solyc01g109660.2.1 & 114 & 10 & 6 & 5 & 3 & 44 & 39.04 \\
\hline Solyc $10 \mathrm{~g} 078740.1 .1$ & 114 & 6 & 6 & 5 & 5 & 17.6 & 56.61 \\
\hline Solyc09g082780.2.1 & 114 & 5 & 5 & 3 & 3 & 16.7 & 69.03 \\
\hline Solyc03g112070.2.1 & 114 & 3 & 3 & 2 & 2 & 5.7 & 64.66 \\
\hline Solyc10g081030.1.1 & 113 & 6 & 6 & 2 & 2 & 15.6 & 62.45 \\
\hline Solyc02g023970.2.1 & 113 & 4 & 4 & 4 & 4 & 14 & 57.1 \\
\hline Solyc08g075700.2.1 & 113 & 1 & 1 & 1 & 1 & 11.7 & 113.13 \\
\hline Solyc11g069000.1.1 & 113 & 2 & 2 & 2 & 2 & 8 & 98.19 \\
\hline Solyc04g009410.2.1 & 112 & 2 & 2 & 2 & 2 & 15.7 & 85.72 \\
\hline Solyc09g090600.2.1 & 112 & 3 & 3 & 2 & 2 & 14.8 & 56.73 \\
\hline Solyc01g044360.2.1 & 112 & 1 & 1 & 1 & 1 & 2.1 & 111.92 \\
\hline Solyc11g072450.1.1 & 110 & 8 & 8 & 6 & 6 & 38.1 & 47.96 \\
\hline Solyc10g084400.1.1 & 110 & 4 & 3 & 3 & 2 & 17.9 & 73.23 \\
\hline Solyc06g069010.2.1 & 110 & 5 & 5 & 4 & 4 & 17.5 & 59.35 \\
\hline Solyc01g095150.2.1 & 109 & 5 & 4 & 4 & 3 & 29.9 & 47.14 \\
\hline Solyc06g082120.2.1 & 109 & 3 & 2 & 2 & 1 & 21.3 & 64.56 \\
\hline Solyc04g080540.2.1 & 109 & 1 & 1 & 1 & 1 & 14.2 & 109.08 \\
\hline Solyc05g054760.2.1 & 108 & 5 & 5 & 5 & 5 & 31.9 & 51.06 \\
\hline Solyc02g063130.2.1 & 108 & 6 & 6 & 4 & 4 & 17 & 45.28 \\
\hline Solyc02g077420.2.1 & 108 & 4 & 4 & 4 & 4 & 15.4 & 48.01 \\
\hline Solyc03g080180.2.1 & 108 & 3 & 3 & 3 & 3 & 13.7 & 54.56 \\
\hline
\end{tabular}


Supplemental Table 2. Continued.

\begin{tabular}{|c|c|c|c|c|c|c|c|}
\hline Accession $^{y}$ & $\begin{array}{l}\text { Protein } \\
\text { score }^{\mathrm{x}}\end{array}$ & $\begin{array}{c}\text { Total } \\
\text { matches (no.) }\end{array}$ & $\begin{array}{c}\text { Unique } \\
\text { matches (no.) }\end{array}$ & $\begin{array}{c}\text { Total } \\
\text { sequences (no.) })^{\mathrm{u}}\end{array}$ & $\begin{array}{c}\text { Unique } \\
\text { sequences (no.) }\end{array}$ & $\begin{array}{c}\text { Protein } \\
\text { coverage }(\%)^{\mathrm{s}}\end{array}$ & $\begin{array}{c}\text { Highest } \\
\text { peptide score }\end{array}$ \\
\hline 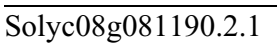 & 108 & 4 & 4 & 2 & 2 & 11.9 & 59.46 \\
\hline Solyc03g123630.2.1 & 108 & 5 & 4 & 5 & 4 & 11.3 & 44.61 \\
\hline Solyc01g103750.2.1 & 108 & 1 & 1 & 1 & 1 & 5.6 & 107.83 \\
\hline Solyc01g011000.2.1 & 107 & 4 & 3 & 4 & 3 & 28.3 & 71.2 \\
\hline Solyc03g097270.2.1 & 107 & 3 & 2 & 3 & 2 & 21.7 & 65.42 \\
\hline Solyc05g055760.2.1 & 107 & 4 & 3 & 4 & 3 & 20 & 60.67 \\
\hline Solyc05g056390.2.1 & 104 & 5 & 5 & 4 & 4 & 51.5 & 40.94 \\
\hline Solyc05g055230.1.1 & 104 & 5 & 5 & 2 & 2 & 26.4 & 43.93 \\
\hline Solyc09g091470.2.1 & 104 & 5 & 4 & 5 & 4 & 15.7 & 57.47 \\
\hline Solyc02g080810.2.1 & 104 & 2 & 2 & 2 & 2 & 10.3 & 69.11 \\
\hline Solyc05g050120.2.1 & 102 & 6 & 6 & 6 & 6 & 17.4 & 53.6 \\
\hline Solyc06g073370.2.1 & 102 & 1 & 1 & 1 & 1 & 13.2 & 102.49 \\
\hline Solyc11g062130.1.1 & 102 & 3 & 3 & 3 & 3 & 11.1 & 74.5 \\
\hline Solyc11g012870.1.1 & 102 & 2 & 2 & 2 & 2 & 9.2 & 70.34 \\
\hline Solyc01g079940.2.1 & 102 & 2 & 2 & 2 & 2 & 8.8 & 81.59 \\
\hline Solyc01g087120.2.1 & 101 & 6 & 5 & 4 & 3 & 17.6 & 45.83 \\
\hline Solyc04g074480.2.1 & 101 & 3 & 3 & 3 & 3 & 9.1 & 68.39 \\
\hline Solyc02g093900.2.1 & 101 & 2 & 2 & 1 & 1 & 6.3 & 65.65 \\
\hline Solyc06g007670.2.1 & 100 & 4 & 3 & 3 & 2 & 12 & 49.72 \\
\hline Solyc02g079510.2.1 & 100 & 5 & 4 & 3 & 3 & 9.4 & 48.74 \\
\hline Solyc06g050770.2.1 & 100 & 3 & 3 & 2 & 2 & 9 & 57.92 \\
\hline Solyc12g096520.1.1 & 100 & 1 & 1 & 1 & 1 & 7.5 & 99.67 \\
\hline Solyc01g109540.2.1 & 100 & 4 & 3 & 3 & 2 & 5.6 & 66.78 \\
\hline Solyc06g075010.2.1 & 100 & 2 & 2 & 2 & 2 & 4.9 & 67.18 \\
\hline Solyc09g018750.2.1 & 99 & 3 & 2 & 3 & 2 & 25.9 & 65.03 \\
\hline Solyc02g068450.2.1 & 98 & 3 & 1 & 3 & 1 & 45.6 & 96.37 \\
\hline Solyc08g077930.2.1 & 98 & 4 & 4 & 4 & 4 & 20.2 & 53.25 \\
\hline Solyc01g104110.2.1 & 98 & 4 & 4 & 4 & 4 & 19.6 & 52.42 \\
\hline Solyc11g069430.1.1 & 98 & 3 & 3 & 3 & 3 & 16.4 & 66.92 \\
\hline Solyc $10 \mathrm{~g} 005260.2 .1$ & 98 & 2 & 2 & 2 & 2 & 7.3 & 97.46 \\
\hline Solyc01g008000.2.1 & 97 & 6 & 5 & 6 & 5 & 37.8 & 51.95 \\
\hline Solyc08g015690.2.1 & 97 & 6 & 5 & 6 & 5 & 24.6 & 41.76 \\
\hline Solyc03g033710.2.1 & 97 & 3 & 2 & 3 & 2 & 13.8 & 70.4 \\
\hline Solyc04g074230.2.1 & 97 & 7 & 7 & 2 & 2 & 10.9 & 39.29 \\
\hline Solyc12g008630.1.1 & 97 & 2 & 2 & 2 & 2 & 9.9 & 84.08 \\
\hline Solyc06g082580.2.1 & 97 & 1 & 1 & 1 & 1 & 7.9 & 97.36 \\
\hline Solyc07g016150.2.1 & 96 & 2 & 2 & 2 & 2 & 23.7 & 88.75 \\
\hline Solyc01g006900.2.1 & 96 & 4 & 4 & 2 & 2 & 15.1 & 65.11 \\
\hline Solyc03g079930.2.1 & 96 & 3 & 3 & 2 & 2 & 15.1 & 51.81 \\
\hline Solyc09g091180.2.1 & 96 & 7 & 6 & 5 & 4 & 14 & 40.56 \\
\hline Solyc07g053540.1.1 & 96 & 6 & 5 & 2 & 2 & 10.5 & 43.21 \\
\hline Solyc02g093340.2.1 & 96 & 2 & 2 & 2 & 2 & 6.9 & 80.97 \\
\hline Solyc12g056960.1.1 & 96 & 2 & 2 & 2 & 2 & 6.8 & 77.24 \\
\hline Solyc05g052280.2.1 & 95 & 5 & 4 & 4 & 4 & 18 & 54.71 \\
\hline Solyc08g080640.1.1 & 95 & 4 & 3 & 2 & 1 & 11.3 & 59.28 \\
\hline Solyc01g073740.2.1 & 95 & 4 & 4 & 3 & 3 & 9.3 & 57.67 \\
\hline Solyc02g086460.2.1 & 95 & 4 & 4 & 4 & 4 & 1.5 & 61.58 \\
\hline Solyc01g107590.2.1 & 94 & 4 & 3 & 4 & 3 & 24.9 & 49.03 \\
\hline Solyc08g080650.1.1 & 94 & 4 & 3 & 2 & 1 & 17.9 & 59.28 \\
\hline Solyc03g078290.2.1 & 94 & 1 & 1 & 1 & 1 & 13.2 & 94.16 \\
\hline Solyc07g006790.2.1 & 94 & 3 & 3 & 3 & 3 & 7.1 & 60.37 \\
\hline Solyc03g080160.2.1 & 93 & 3 & 2 & 3 & 2 & 21.6 & 61.87 \\
\hline Solyc08g075830.2.1 & 93 & 5 & 4 & 3 & 3 & 13 & 52.41 \\
\hline Solyc02g091490.2.1 & 93 & 3 & 3 & 3 & 3 & 11.8 & 68.37 \\
\hline Solyc06g082870.2.1 & 93 & 4 & 2 & 3 & 1 & 11.6 & 49.72 \\
\hline Solyc02g083590.2.1 & 93 & 2 & 2 & 2 & 2 & 7.7 & 64.61 \\
\hline Solyc07g041490.1.1 & 92 & 1 & 1 & 1 & 1 & 7.1 & 92.47 \\
\hline
\end{tabular}


Supplemental Table 2. Continued.

\begin{tabular}{|c|c|c|c|c|c|c|c|}
\hline Accession $^{y}$ & $\begin{array}{l}\text { Protein } \\
\text { score }^{\mathrm{x}}\end{array}$ & $\begin{array}{c}\text { Total } \\
\text { matches (no.) }\end{array}$ & $\begin{array}{c}\text { Unique } \\
\text { matches (no.) }\end{array}$ & $\begin{array}{c}\text { Total } \\
\text { sequences }(\text { no. })^{\mathrm{u}}\end{array}$ & $\begin{array}{c}\text { Unique } \\
\text { sequences (no.) }\end{array}$ & $\begin{array}{c}\text { Protein } \\
\text { coverage }(\%)^{\mathrm{s}}\end{array}$ & $\begin{array}{c}\text { Highest } \\
\text { peptide score }\end{array}$ \\
\hline Solyc06g050440.2.1 & 91 & 7 & 4 & 3 & 3 & 13.2 & 42.2 \\
\hline Solyc06g083190.2.1 & 91 & 5 & 3 & 4 & 3 & 9.8 & 68.63 \\
\hline Solyc09g091070.1.1 & 90 & 4 & 4 & 4 & 4 & 17.8 & 41.72 \\
\hline Solyc02g082900.2.1 & 90 & 1 & 1 & 1 & 1 & 5.7 & 89.68 \\
\hline Solyc07g008370.2.1 & 89 & 4 & 4 & 4 & 4 & 18.2 & 63.79 \\
\hline Solyc02g079060.2.1 & 89 & 3 & 2 & 2 & 2 & 13.5 & 67.82 \\
\hline Solyc06g060260.2.1 & 89 & 4 & 4 & 2 & 2 & 13 & 44.39 \\
\hline Solyc01g008330.2.1 & 89 & 4 & 4 & 4 & 4 & 12.1 & 51.48 \\
\hline Solyc01g005620.2.1 & 89 & 2 & 2 & 2 & 2 & 12.1 & 71.11 \\
\hline Solyc10g081530.1.1 & 89 & 2 & 2 & 2 & 2 & 5.7 & 80.25 \\
\hline Solyc03g096550.2.1 & 88 & 3 & 2 & 3 & 2 & 23.5 & 73.38 \\
\hline Solyc07g008720.2.1 & 88 & 3 & 2 & 2 & 2 & 21.6 & 76 \\
\hline Solyc05g006520.2.1 & 87 & 5 & 5 & 5 & 5 & 16.9 & 43.85 \\
\hline Solyc05g056020.2.1 & 86 & 2 & 2 & 2 & 2 & 34.2 & 76.13 \\
\hline Solyc09g009640.2.1 & 86 & 1 & 1 & 1 & 1 & 18.2 & 86.27 \\
\hline Solyc08g080660.1.1 & 86 & 5 & 4 & 2 & 2 & 12.8 & 43.29 \\
\hline Solyc04g011350.2.1 & 86 & 1 & 1 & 1 & 1 & 1.9 & 85.82 \\
\hline Solyc12g008940.1.1 & 85 & 4 & 2 & 4 & 2 & 13.6 & 54.45 \\
\hline Solyc09g075450.2.1 & 85 & 3 & 3 & 3 & 3 & 10.1 & 53.01 \\
\hline Solyc03g096000.2.1 & 85 & 2 & 2 & 2 & 2 & 1.6 & 72.71 \\
\hline Solyc04g011390.1.1 & 84 & 4 & 4 & 3 & 3 & 29.1 & 58.68 \\
\hline Solyc07g065110.1.1 & 84 & 3 & 3 & 2 & 2 & 27.9 & 65.88 \\
\hline Solyc05g012070.2.1 & 84 & 5 & 5 & 5 & 5 & 23.8 & 55.1 \\
\hline Solyc12g010060.1.1 & 84 & 3 & 3 & 3 & 3 & 22.5 & 51.58 \\
\hline Solyc06g074780.1.1 & 84 & 4 & 4 & 1 & 1 & 10.5 & 50.12 \\
\hline Solyc11g011470.1.1 & 84 & 4 & 3 & 4 & 3 & 9.5 & 47.66 \\
\hline Solyc11g020870.1.1 & 84 & 1 & 1 & 1 & 1 & 5.9 & 83.62 \\
\hline Solyc04g076880.2.1 & 84 & 2 & 2 & 2 & 2 & 4.8 & 63.2 \\
\hline Solyc03g119360.2.1 & 83 & 4 & 4 & 3 & 3 & 20.4 & 55.97 \\
\hline Solyc03g118040.2.1 & 83 & 5 & 4 & 4 & 3 & 11.9 & 36.49 \\
\hline Solyc09g025240.2.1 & 83 & 2 & 2 & 2 & 2 & 10 & 65.7 \\
\hline Solyc01g098880.2.1 & 83 & 3 & 2 & 3 & 2 & 9.8 & 56.22 \\
\hline Solyc01g087850.2.1 & 83 & 4 & 3 & 4 & 3 & 9.2 & 43.53 \\
\hline Solyc04g082160.2.1 & 83 & 2 & 2 & 2 & 2 & 6.9 & 65.28 \\
\hline Solyc09g007250.2.1 & 82 & 3 & 3 & 2 & 2 & 6.9 & 38.91 \\
\hline Solyc03g121070.2.1 & 82 & 2 & 2 & 2 & 2 & 6.8 & 63.74 \\
\hline Solyc12g042060.1.1 & 82 & 3 & 3 & 3 & 3 & 6.3 & 43.14 \\
\hline Solyc06g062950.1.1 & 82 & 3 & 3 & 3 & 3 & 5.7 & 45.76 \\
\hline Solyc01g104950.2.1 & 82 & 2 & 2 & 2 & 2 & 4.1 & 74.27 \\
\hline Solyc08g077910.2.1 & 81 & 1 & 1 & 1 & 1 & 9.2 & 80.54 \\
\hline Solyc01g111150.2.1 & 81 & 3 & 3 & 1 & 1 & 5.8 & 44.99 \\
\hline Solyc05g054710.2.1 & 81 & 2 & 2 & 1 & 1 & 2.5 & 65.29 \\
\hline Solyc04g080880.2.1 & 81 & 1 & 1 & 1 & 1 & 2.2 & 80.57 \\
\hline Solyc05g013990.2.1 & 80 & 2 & 2 & 2 & 2 & 8 & 52.64 \\
\hline Solyc01g088080.2.1 & 80 & 2 & 2 & 2 & 2 & 6.5 & 57.81 \\
\hline Solyc01g100360.2.1 & 80 & 2 & 2 & 2 & 2 & 6.3 & 66.18 \\
\hline Solyc06g005670.2.1 & 80 & 1 & 1 & 1 & 1 & 2.2 & 79.9 \\
\hline Solyc01g088610.2.1 & 79 & 2 & 2 & 2 & 2 & 28.1 & 61.7 \\
\hline Solyc12g044850.1.1 & 79 & 1 & 1 & 1 & 1 & 14.1 & 79.45 \\
\hline Solyc07g062610.2.1 & 79 & 2 & 2 & 2 & 2 & 8.7 & 69.46 \\
\hline Solyc09g061840.2.1 & 79 & 2 & 2 & 2 & 2 & 6.6 & 50.55 \\
\hline Solyc10g084120.1.1 & 79 & 2 & 2 & 1 & 1 & 6.4 & 57.96 \\
\hline Solyc09g075940.2.1 & 79 & 1 & 1 & 1 & 1 & 2.7 & 78.52 \\
\hline Solyc01g099830.2.1 & 78 & 2 & 2 & 2 & 2 & 28.8 & 57.77 \\
\hline Solyc10g084350.1.1 & 78 & 2 & 2 & 2 & 2 & 13.6 & 56.15 \\
\hline Solyc02g086730.1.1 & 78 & 1 & 1 & 1 & 1 & 9.5 & 78.1 \\
\hline Solyc06g065470.2.1 & 78 & 3 & 2 & 1 & 1 & 7.7 & 46.94 \\
\hline
\end{tabular}


Supplemental Table 2. Continued.

\begin{tabular}{|c|c|c|c|c|c|c|c|}
\hline Accession $^{y}$ & $\begin{array}{l}\text { Protein } \\
\text { score }^{\mathrm{x}}\end{array}$ & $\begin{array}{c}\text { Total } \\
\text { matches (no.) }\end{array}$ & $\begin{array}{c}\text { Unique } \\
\text { matches (no.) }\end{array}$ & $\begin{array}{c}\text { Total } \\
\text { sequences }(\text { no. })^{\mathrm{u}}\end{array}$ & $\begin{array}{c}\text { Unique } \\
\text { sequences }(\text { no. })^{t}\end{array}$ & $\begin{array}{c}\text { Protein } \\
\text { coverage }(\%)^{\mathrm{s}}\end{array}$ & $\begin{array}{c}\text { Highest } \\
\text { peptide score }\end{array}$ \\
\hline Solyc06g050590.2.1 & 78 & 1 & 1 & 1 & 1 & 6.2 & 78.13 \\
\hline Solyc06g007200.2.1 & 78 & 1 & 1 & 1 & 1 & 4.4 & 77.73 \\
\hline Solyc09g010420.2.1 & 78 & 1 & 1 & 1 & 1 & 4 & 78.43 \\
\hline Solyc01g099780.2.1 & 77 & 4 & 3 & 4 & 3 & 28.6 & 35.14 \\
\hline Solyc06g049080.2.1 & 77 & 2 & 2 & 2 & 2 & 14.9 & 50.92 \\
\hline Solyc07g064800.2.1 & 77 & 4 & 3 & 3 & 2 & 11.5 & 63.97 \\
\hline Solyc01g104590.2.1 & 77 & 3 & 2 & 3 & 2 & 10.3 & 53.76 \\
\hline Solyc04g074410.1.1 & 77 & 1 & 1 & 1 & 1 & 6.7 & 76.67 \\
\hline Solyc07g064240.2.1 & 77 & 2 & 2 & 1 & 1 & 6.4 & 52.46 \\
\hline Solyc02g088700.2.1 & 77 & 2 & 2 & 2 & 2 & 5.8 & 51.87 \\
\hline Solyc06g011280.2.1 & 77 & 1 & 1 & 1 & 1 & 4.6 & 76.71 \\
\hline Solyc12g099570.1.1 & 76 & 1 & 1 & 1 & 1 & 44.4 & 75.85 \\
\hline Solyc01g099410.2.1 & 76 & 2 & 2 & 1 & 1 & 15.8 & 67.18 \\
\hline Solyc07g017400.2.1 & 76 & 3 & 3 & 2 & 2 & 9 & 40.65 \\
\hline Solyc06g063140.2.1 & 76 & 2 & 2 & 2 & 2 & 7.7 & 50.89 \\
\hline Solyc11g008870.1.1 & 76 & 3 & 3 & 3 & 3 & 7.1 & 45.36 \\
\hline Solyc05g009600.2.1 & 76 & 1 & 1 & 1 & 1 & 3.2 & 75.7 \\
\hline Solyc04g082560.2.1 & 76 & 1 & 1 & 1 & 1 & 1.6 & 75.88 \\
\hline Solyc03g025850.2.1 & 75 & 4 & 3 & 4 & 3 & 25.9 & 60.63 \\
\hline Solyc10g079830.1.1 & 75 & 1 & 1 & 1 & 1 & 13.1 & 74.63 \\
\hline Solyc10g074500.1.1 & 75 & 3 & 2 & 3 & 2 & 11.8 & 60.56 \\
\hline Solyc03g032000.2.1 & 74 & 3 & 3 & 3 & 3 & 19.8 & 43.61 \\
\hline Solyc11g068430.1.1 & 74 & 1 & 1 & 1 & 1 & 16.1 & 73.94 \\
\hline Solyc01g008970.2.1 & 74 & 3 & 2 & 3 & 2 & 13.6 & 46.24 \\
\hline Solyc02g082200.2.1 & 74 & 1 & 1 & 1 & 1 & 10.2 & 74.05 \\
\hline Solyc03g096460.2.1 & 74 & 2 & 2 & 1 & 1 & 9.8 & 54.83 \\
\hline Solyc02g078920.2.1 & 74 & 1 & 1 & 1 & 1 & 7.4 & 73.59 \\
\hline Solyc04g015830.2.1 & 74 & 3 & 2 & 3 & 2 & 5.2 & 56.33 \\
\hline Solyc10g008010.2.1 & 73 & 3 & 3 & 3 & 3 & 29.8 & 43.77 \\
\hline Solyc06g007710.2.1 & 73 & 2 & 1 & 2 & 1 & 10.2 & 66.84 \\
\hline Solyc04g045340.2.1 & 73 & 3 & 3 & 3 & 3 & 9.6 & 56.29 \\
\hline Solyc08g006850.2.1 & 73 & 2 & 2 & 2 & 2 & 7.4 & 51.42 \\
\hline Solyc01g097520.2.1 & 73 & 1 & 1 & 1 & 1 & 5.7 & 72.94 \\
\hline Solyc12g088760.1.1 & 73 & 2 & 2 & 2 & 2 & 4.4 & 52.44 \\
\hline Solyc09g075150.2.1 & 72 & 2 & 2 & 2 & 2 & 29 & 57.77 \\
\hline Solyc01g102390.2.1 & 72 & 3 & 2 & 2 & 2 & 13.2 & 46.06 \\
\hline Solyc10g086010.1.1 & 72 & 2 & 2 & 2 & 2 & 8.3 & 56.15 \\
\hline Solyc05g012270.2.1 & 72 & 2 & 2 & 2 & 2 & 5.9 & 68.22 \\
\hline Solyc03g031720.2.1 & 72 & 1 & 1 & 1 & 1 & 5.2 & 72.35 \\
\hline Solyc11g067230.1.1 & 72 & 1 & 1 & 1 & 1 & 4.4 & 71.5 \\
\hline Solyc02g077240.2.1 & 72 & 1 & 1 & 1 & 1 & 3.4 & 71.65 \\
\hline Solyc07g055080.2.1 & 71 & 2 & 2 & 2 & 2 & 17.4 & 58.88 \\
\hline Solyc02g081700.1.1 & 71 & 4 & 3 & 3 & 2 & 15.7 & 40.27 \\
\hline Solyc02g088790.2.1 & 71 & 3 & 3 & 2 & 2 & 11.8 & 51.01 \\
\hline Solyc02g069090.2.1 & 71 & 2 & 2 & 2 & 2 & 11.6 & 55.1 \\
\hline Solyc01g090120.2.1 & 71 & 1 & 1 & 1 & 1 & 10.1 & 71.37 \\
\hline Solyc01g112080.2.1 & 71 & 2 & 2 & 2 & 2 & 8.7 & 47.88 \\
\hline Solyc09g007900.2.1 & 71 & 2 & 2 & 2 & 2 & 5.5 & 47.72 \\
\hline Solyc08g041710.2.1 & 71 & 1 & 1 & 1 & 1 & 3.6 & 71.19 \\
\hline Solyc03g045050.2.1 & 71 & 1 & 1 & 1 & 1 & 1.9 & 70.72 \\
\hline Solyc03g120470.2.1 & 71 & 1 & 1 & 1 & 1 & 1.5 & 70.73 \\
\hline Solyc01g099900.2.1 & 70 & 3 & 3 & 3 & 3 & 20.3 & 46.09 \\
\hline Solyc05g015390.2.1 & 70 & 2 & 2 & 2 & 2 & 13 & 62.34 \\
\hline Solyc02g086740.1.1 & 70 & 1 & 1 & 1 & 1 & 9.7 & 69.79 \\
\hline Solyc09g089880.2.1 & 70 & 1 & 1 & 1 & 1 & 8.8 & 70.5 \\
\hline Solyc02g086240.2.1 & 70 & 2 & 2 & 1 & 1 & 7.7 & 55.78 \\
\hline Solyc05g050970.2.1 & 70 & 6 & 4 & 5 & 4 & 7.5 & 39.35 \\
\hline
\end{tabular}


Supplemental Table 2. Continued.

\begin{tabular}{|c|c|c|c|c|c|c|c|}
\hline Accession $^{y}$ & $\begin{array}{l}\text { Protein } \\
\text { score }^{\mathrm{x}}\end{array}$ & $\begin{array}{c}\text { Total } \\
\text { matches (no.) }{ }^{\mathrm{w}}\end{array}$ & $\begin{array}{c}\text { Unique } \\
\text { matches (no.) }{ }^{\mathrm{v}}\end{array}$ & $\begin{array}{c}\text { Total } \\
\text { sequences }(\text { no. })^{\mathrm{u}}\end{array}$ & $\begin{array}{c}\text { Unique } \\
\text { sequences (no.) }\end{array}$ & $\begin{array}{c}\text { Protein } \\
\text { coverage }(\%)^{\mathrm{s}}\end{array}$ & $\begin{array}{c}\text { Highest } \\
\text { peptide score }\end{array}$ \\
\hline Solyc09g075460.2.1 & 70 & 2 & 2 & 2 & 2 & 6.7 & 57.64 \\
\hline Solyc06g060760.2.1 & 70 & 2 & 2 & 1 & 1 & 6.4 & 52.42 \\
\hline Solyc08g079090.2.1 & 70 & 2 & 2 & 2 & 2 & 5.6 & 61.05 \\
\hline Solyc10g081720.1.1 & 70 & 1 & 1 & 1 & 1 & 3.8 & 70.44 \\
\hline Solyc01g097300.2.1 & 69 & 1 & 1 & 1 & 1 & 15.6 & 69.16 \\
\hline Solyc07g005560.2.1 & 69 & 1 & 1 & 1 & 1 & 11.9 & 68.73 \\
\hline Solyc11g051160.1.1 & 69 & 3 & 3 & 3 & 3 & 9.8 & 41 \\
\hline Solyc10g083720.1.1 & 69 & 2 & 2 & 2 & 2 & 6.3 & 48.73 \\
\hline Solyc08g075090.2.1 & 69 & 3 & 3 & 3 & 3 & 5.6 & 53.65 \\
\hline Solyc11g069400.1.1 & 69 & 2 & 1 & 2 & 1 & 5.2 & 58.46 \\
\hline Solyc03g111640.2.1 & 69 & 1 & 1 & 1 & 1 & 2.6 & 69.16 \\
\hline Solyc12g042900.1.1 & 68 & 2 & 2 & 2 & 2 & 14.5 & 59.2 \\
\hline Solyc05g051510.2.1 & 68 & 2 & 2 & 2 & 2 & 14.4 & 52.64 \\
\hline Solyc05g056490.2.1 & 68 & 2 & 2 & 2 & 2 & 12.9 & 46.99 \\
\hline Solyc02g094180.2.1 & 68 & 2 & 2 & 2 & 2 & 10.8 & 52.59 \\
\hline Solyc04g080590.2.1 & 68 & 2 & 2 & 2 & 2 & 9.8 & 56.26 \\
\hline Solyc08g014340.2.1 & 68 & 4 & 3 & 2 & 2 & 9.6 & 33.83 \\
\hline Solyc01g097270.2.1 & 68 & 2 & 2 & 1 & 1 & 8.5 & 48.11 \\
\hline Solyc02g080630.2.1 & 68 & 2 & 2 & 2 & 2 & 8.2 & 43.36 \\
\hline Solyc10g006400.2.1 & 68 & 2 & 2 & 2 & 2 & 6.6 & 51.28 \\
\hline Solyc09g083410.2.1 & 68 & 1 & 1 & 1 & 1 & 3.9 & 68.5 \\
\hline Solyc07g007210.2.1 & 68 & 1 & 1 & 1 & 1 & 2.3 & 67.98 \\
\hline Solyc03g083520.2.1 & 67 & 4 & 3 & 4 & 3 & 29.3 & 37.53 \\
\hline Solyc10g051390.1.1 & 67 & 2 & 2 & 2 & 2 & 22 & 50.31 \\
\hline Solyc03g097290.2.1 & 67 & 2 & 2 & 2 & 2 & 3.3 & 53.51 \\
\hline Solyc12g056230.1.1 & 66 & 2 & 2 & 2 & 2 & 13.5 & 44.53 \\
\hline Solyc01g109940.2.1 & 66 & 3 & 3 & 3 & 3 & 11.8 & 39.56 \\
\hline Solyc01g080510.2.1 & 66 & 2 & 1 & 2 & 1 & 10.6 & 60.12 \\
\hline Solyc08g065640.2.1 & 66 & 1 & 1 & 1 & 1 & 10.3 & 65.78 \\
\hline Solyc10g077030.1.1 & 66 & 1 & 1 & 1 & 1 & 6.8 & 66.21 \\
\hline Solyc01g109850.2.1 & 66 & 2 & 2 & 2 & 2 & 6.5 & 47.76 \\
\hline Solyc06g068090.2.1 & 66 & 3 & 1 & 3 & 1 & 6.2 & 43.64 \\
\hline Solyc06g083300.2.1 & 66 & 2 & 2 & 2 & 2 & 5.5 & 49.66 \\
\hline Solyc01g080220.2.1 & 65 & 2 & 2 & 2 & 2 & 19.3 & 58.66 \\
\hline Solyc01g105060.2.1 & 65 & 3 & 2 & 3 & 2 & 17.8 & 42.08 \\
\hline Solyc04g011400.2.1 & 65 & 2 & 2 & 2 & 2 & 13.1 & 50.22 \\
\hline Solyc10g005890.2.1 & 65 & 3 & 2 & 3 & 2 & 10.8 & 52.41 \\
\hline Solyc02g068740.2.1 & 65 & 2 & 2 & 1 & 1 & 10.4 & 52.64 \\
\hline Solyc10g049890.1.1 & 65 & 3 & 3 & 3 & 3 & 8.2 & 42.56 \\
\hline Solyc03g123610.2.1 & 65 & 3 & 3 & 3 & 3 & 7.1 & 36.49 \\
\hline Solyc06g083030.2.1 & 65 & 2 & 1 & 2 & 1 & 6.4 & 61 \\
\hline Solyc02g067840.2.1 & 65 & 1 & 1 & 1 & 1 & 5.3 & 64.74 \\
\hline Solyc12g042380.1.1 & 65 & 1 & 1 & 1 & 1 & 4.1 & 65.35 \\
\hline Solyc06g064940.2.1 & 65 & 1 & 1 & 1 & 1 & 3.3 & 65.36 \\
\hline Solyc05g053780.2.1 & 64 & 3 & 3 & 3 & 3 & 26.7 & 36.55 \\
\hline Solyc10g080970.1.1 & 64 & 4 & 3 & 4 & 3 & 21.7 & 36.66 \\
\hline Solyc09g011660.2.1 & 64 & 2 & 2 & 2 & 2 & 21.3 & 53.65 \\
\hline Solyc01g097870.2.1 & 64 & 2 & 2 & 2 & 2 & 19.5 & 48.2 \\
\hline Solyc01g097880.2.1 & 64 & 2 & 2 & 2 & 2 & 15.6 & 59.39 \\
\hline Solyc10g081180.1.1 & 64 & 2 & 1 & 2 & 1 & 13.2 & 65.74 \\
\hline Solyc09g090010.2.1 & 64 & 1 & 1 & 1 & 1 & 10.3 & 64.11 \\
\hline Solyc05g013030.1.1 & 64 & 3 & 2 & 3 & 2 & 9.5 & 51.06 \\
\hline Solyc03g082580.2.1 & 64 & 2 & 2 & 2 & 2 & 8.8 & 54.93 \\
\hline Solyc02g063090.2.1 & 64 & 2 & 2 & 2 & 2 & 8.2 & 52.36 \\
\hline Solyc10g050890.1.1 & 64 & 2 & 2 & 2 & 2 & 4.8 & 51.69 \\
\hline Solyc12g055830.1.1 & 63 & 3 & 3 & 3 & 3 & 26.8 & 40.39 \\
\hline Solyc06g073700.2.1 & 63 & 1 & 1 & 1 & 1 & 16.3 & 62.58 \\
\hline
\end{tabular}


Supplemental Table 2. Continued.

\begin{tabular}{|c|c|c|c|c|c|c|c|}
\hline Accession $^{y}$ & $\begin{array}{l}\text { Protein } \\
\text { score }^{\mathrm{x}}\end{array}$ & $\begin{array}{c}\text { Total } \\
\text { matches (no.) }\end{array}$ & $\begin{array}{c}\text { Unique } \\
\text { matches (no.) }\end{array}$ & $\begin{array}{c}\text { Total } \\
\text { sequences (no.) })^{\mathrm{u}}\end{array}$ & $\begin{array}{c}\text { Unique } \\
\text { sequences (no.) }\end{array}$ & $\begin{array}{c}\text { Protein } \\
\text { coverage }(\%)^{\mathrm{s}}\end{array}$ & $\begin{array}{c}\text { Highest } \\
\text { peptide score }\end{array}$ \\
\hline $\begin{array}{l}\text { Solyc01g097460.2.1 } \\
\end{array}$ & 63 & 2 & 2 & 2 & 2 & 13.3 & 45.22 \\
\hline Solyc03g005680.2.1 & 63 & 5 & 2 & 4 & 2 & 12.9 & 37.85 \\
\hline Solyc02g081170.2.1 & 63 & 2 & 2 & 2 & 2 & 11.3 & 44.74 \\
\hline Solyc06g073280.2.1 & 63 & 2 & 2 & 2 & 2 & 9.5 & 49.32 \\
\hline Solyc04g079200.2.1 & 63 & 2 & 2 & 2 & 2 & 9 & 50.38 \\
\hline Solyc05g007940.2.1 & 63 & 1 & 1 & 1 & 1 & 7.6 & 62.65 \\
\hline Solyc02g082800.2.1 & 63 & 2 & 2 & 2 & 2 & 5.4 & 40.28 \\
\hline Solyc02g086520.2.1 & 63 & 1 & 1 & 1 & 1 & 2.9 & 62.51 \\
\hline Solyc10g086510.1.1 & 62 & 2 & 2 & 2 & 2 & 26.9 & 50.34 \\
\hline Solyc04g072060.2.1 & 62 & 1 & 1 & 1 & 1 & 12.7 & 61.76 \\
\hline Solyc06g065520.2.1 & 62 & 3 & 3 & 3 & 3 & 7.9 & 40.12 \\
\hline Solyc02g068640.2.1 & 62 & 1 & 1 & 1 & 1 & 6.5 & 61.94 \\
\hline Solyc09g075010.2.1 & 62 & 2 & 1 & 1 & 1 & 5.8 & 56.2 \\
\hline Solyc09g013080.2.1 & 62 & 2 & 1 & 2 & 1 & 3.4 & 54.68 \\
\hline Solyc01g079540.2.1 & 61 & 2 & 2 & 2 & 2 & 17.6 & 48.1 \\
\hline Solyc01g104370.2.1 & 61 & 1 & 1 & 1 & 1 & 14.3 & 61.01 \\
\hline Solyc01g079680.2.1 & 61 & 3 & 3 & 3 & 3 & 9.3 & 37.09 \\
\hline Solyc06g053460.1.1 & 61 & 2 & 2 & 2 & 2 & 8.9 & 48.58 \\
\hline Solyc09g066490.2.1 & 61 & 1 & 1 & 1 & 1 & 7.1 & 61.09 \\
\hline Solyc06g068320.2.1 & 61 & 2 & 2 & 2 & 2 & 5.4 & 45.81 \\
\hline Solyc04g080960.2.1 & 61 & 1 & 1 & 1 & 1 & 5.2 & 60.51 \\
\hline Solyc07g008560.2.1 & 61 & 2 & 1 & 2 & 1 & 4.4 & 49.75 \\
\hline Solyc06g005360.2.1 & 60 & 2 & 2 & 2 & 2 & 23.4 & 50.88 \\
\hline Solyc02g021400.1.1 & 60 & 1 & 1 & 1 & 1 & 18.5 & 60.48 \\
\hline Solyc03g120090.1.1 & 60 & 2 & 1 & 2 & 1 & 11.1 & 51.95 \\
\hline Solyc11g017070.1.1 & 60 & 1 & 1 & 1 & 1 & 9.5 & 59.64 \\
\hline Solyc01g106080.2.1 & 60 & 2 & 2 & 2 & 2 & 8.6 & 50.01 \\
\hline Solyc01g106080.2.1 & 60 & 2 & 2 & 2 & 2 & 8.6 & 33.19 \\
\hline Solyc02g082830.1.1 & 60 & 2 & 2 & 2 & 2 & 7.4 & 41.11 \\
\hline Solyc05g006750.2.1 & 60 & 1 & 1 & 1 & 1 & 7.4 & 60.49 \\
\hline Solyc08g081570.2.1 & 60 & 1 & 1 & 1 & 1 & 7 & 59.6 \\
\hline Solyc08g041870.2.1 & 60 & 2 & 2 & 2 & 2 & 5.8 & 43.72 \\
\hline Solyc06g074820.2.1 & 60 & 1 & 1 & 1 & 1 & 5.6 & 60.15 \\
\hline Solyc01g094200.2.1 & 60 & 1 & 1 & 1 & 1 & 2.8 & 60.42 \\
\hline Solyc11g007200.1.1 & 59 & 2 & 1 & 2 & 1 & 26.5 & 56.17 \\
\hline Solyc10g081310.1.1 & 59 & 2 & 2 & 2 & 2 & 20.8 & 49.47 \\
\hline Solyc06g084310.2.1 & 59 & 1 & 1 & 1 & 1 & 17.5 & 59.16 \\
\hline Solyc06g005810.2.1 & 59 & 2 & 2 & 2 & 2 & 14.4 & 49.47 \\
\hline Solyc02g078360.2.1 & 59 & 2 & 1 & 2 & 1 & 13.9 & 48.08 \\
\hline Solyc09g064940.2.1 & 59 & 2 & 2 & 2 & 2 & 11 & 50.72 \\
\hline Solyc08g068310.2.1 & 59 & 2 & 2 & 2 & 2 & 7.3 & 42.53 \\
\hline Solyc07g055060.2.1 & 59 & 3 & 3 & 3 & 3 & 5.2 & 38.03 \\
\hline Solyc07g064880.2.1 & 58 & 2 & 2 & 2 & 2 & 43.4 & 52.75 \\
\hline Solyc06g008260.2.1 & 58 & 2 & 2 & 1 & 1 & 9 & 38.8 \\
\hline Solyc12g009590.1.1 & 58 & 2 & 1 & 2 & 1 & 8.8 & 44.44 \\
\hline Solyc03g044010.2.1 & 58 & 1 & 1 & 1 & 1 & 7.7 & 57.59 \\
\hline Solyc01g097010.2.1 & 58 & 2 & 2 & 2 & 2 & 7.2 & 48.6 \\
\hline Solyc10g081120.1.1 & 58 & 2 & 1 & 2 & 1 & 5 & 56.62 \\
\hline Solyc09g018450.2.1 & 58 & 1 & 1 & 1 & 1 & 1.8 & 57.69 \\
\hline Solyc04g026100.1.1 & 57 & 2 & 2 & 2 & 2 & 17 & 53.57 \\
\hline Solyc07g045350.2.1 & 57 & 2 & 2 & 2 & 2 & 13.9 & 42.22 \\
\hline Solyc01g080280.2.1 & 57 & 2 & 1 & 2 & 1 & 9.7 & 56.55 \\
\hline Solyc05g018810.2.1 & 57 & 3 & 1 & 3 & 1 & 9.3 & 36.33 \\
\hline Solyc04g054990.2.1 & 57 & 1 & 1 & 1 & 1 & 9.3 & 56.65 \\
\hline Solyc04g015620.2.1 & 57 & 2 & 1 & 2 & 1 & 7.8 & 46.56 \\
\hline Solyc02g082270.2.1 & 57 & 1 & 1 & 1 & 1 & 6.4 & 57.48 \\
\hline Solyc10g082030.1.1 & 57 & 1 & 1 & 1 & 1 & 6.4 & 57 \\
\hline
\end{tabular}


Supplemental Table 2. Continued.

\begin{tabular}{|c|c|c|c|c|c|c|c|}
\hline Accession $^{y}$ & $\begin{array}{l}\text { Protein } \\
\text { score }^{\mathrm{x}}\end{array}$ & $\begin{array}{c}\text { Total } \\
\text { matches (no.) }\end{array}$ & $\begin{array}{c}\text { Unique } \\
\text { matches (no.) }\end{array}$ & $\begin{array}{c}\text { Total } \\
\text { sequences }(\text { no. })^{\mathrm{u}}\end{array}$ & $\begin{array}{c}\text { Unique } \\
\text { sequences (no.) } \\
\end{array}$ & $\begin{array}{c}\text { Protein } \\
\text { coverage }(\%)^{\mathrm{s}}\end{array}$ & $\begin{array}{c}\text { Highest } \\
\text { peptide score }\end{array}$ \\
\hline Solyc10g054280.1.1 & 57 & 2 & 1 & 1 & 1 & 6.1 & 44.25 \\
\hline Solyc03g118030.2.1 & 57 & 2 & 2 & 2 & 2 & 5.3 & 46.02 \\
\hline Solyc09g098150.2.1 & 57 & 3 & 3 & 2 & 2 & 5 & 36.19 \\
\hline Solyc03g118020.2.1 & 57 & 3 & 3 & 3 & 3 & 4.8 & 46.86 \\
\hline Solyc03g118800.2.1 & 57 & 1 & 1 & 1 & 1 & 4.7 & 57.26 \\
\hline Solyc08g082280.2.1 & 57 & 1 & 1 & 1 & 1 & 2.7 & 56.6 \\
\hline Solyc09g014790.2.1 & 57 & 1 & 1 & 1 & 1 & 2.6 & 56.62 \\
\hline Solyc09g010460.2.1 & 57 & 2 & 2 & 2 & 2 & 2.4 & 40.9 \\
\hline Solyc01g059880.2.1 & 56 & 3 & 2 & 3 & 2 & 8.4 & 34.77 \\
\hline Solyc02g085050.2.1 & 56 & 1 & 1 & 1 & 1 & 6.7 & 56.48 \\
\hline Solyc06g071050.2.1 & 56 & 1 & 1 & 1 & 1 & 5.5 & 55.67 \\
\hline Solyc02g069790.2.1 & 56 & 1 & 1 & 1 & 1 & 4.6 & 55.88 \\
\hline Solyc04g007910.2.1 & 56 & 1 & 1 & 1 & 1 & 3.6 & 56.35 \\
\hline Solyc05g015630.2.1 & 55 & 1 & 1 & 1 & 1 & 15.4 & 55.2 \\
\hline Solyc01g103370.2.1 & 55 & 1 & 1 & 1 & 1 & 8.4 & 55.2 \\
\hline Solyc07g066580.2.1 & 55 & 1 & 1 & 1 & 1 & 7 & 54.63 \\
\hline Solyc02g078540.2.1 & 55 & 2 & 2 & 1 & 1 & 5.2 & 36.87 \\
\hline Solyc03g120280.1.1 & 55 & 1 & 1 & 1 & 1 & 4.5 & 55.06 \\
\hline Solyc05g056400.2.1 & 55 & 2 & 2 & 2 & 2 & 3.6 & 44.66 \\
\hline Solyc05g012080.2.1 & 54 & 1 & 1 & 1 & 1 & 15 & 53.63 \\
\hline Solyc09g082520.2.1 & 54 & 2 & 2 & 2 & 2 & 12.7 & 46.41 \\
\hline Solyc04g008810.2.1 & 54 & 1 & 1 & 1 & 1 & 11.7 & 53.53 \\
\hline Solyc09g059040.2.1 & 54 & 2 & 2 & 2 & 2 & 11.6 & 48.03 \\
\hline Solyc02g079750.2.1 & 54 & 2 & 2 & 2 & 2 & 10.9 & 44.55 \\
\hline Solyc01g008550.2.1 & 54 & 2 & 2 & 2 & 2 & 9.7 & 41.56 \\
\hline Solyc06g076970.2.1 & 54 & 1 & 1 & 1 & 1 & 8.7 & 54.15 \\
\hline Solyc03g095190.2.1 & 54 & 1 & 1 & 1 & 1 & 8 & 53.84 \\
\hline Solyc02g078650.2.1 & 54 & 2 & 2 & 2 & 2 & 7 & 46.17 \\
\hline Solyc08g007420.2.1 & 54 & 1 & 1 & 1 & 1 & 5.8 & 54.5 \\
\hline Solyc05g056540.2.1 & 54 & 2 & 2 & 2 & 2 & 5.6 & 44.34 \\
\hline Solyc03g097790.2.1 & 54 & 1 & 1 & 1 & 1 & 5.3 & 54.38 \\
\hline Solyc02g086830.2.1 & 54 & 1 & 1 & 1 & 1 & 5.3 & 53.65 \\
\hline Solyc10g007600.2.1 & 54 & 2 & 2 & 1 & 1 & 4.6 & 39.89 \\
\hline Solyc07g041900.2.1 & 54 & 1 & 1 & 1 & 1 & 4.5 & 54.37 \\
\hline Solyc01g067750.2.1 & 54 & 1 & 1 & 1 & 1 & 3.5 & 53.91 \\
\hline Solyc05g056310.2.1 & 54 & 1 & 1 & 1 & 1 & 3.2 & 54.15 \\
\hline Solyc12g008720.1.1 & 53 & 1 & 1 & 1 & 1 & 20.8 & 53.17 \\
\hline Solyc02g068150.2.1 & 53 & 1 & 1 & 1 & 1 & 15.4 & 53.22 \\
\hline Solyc04g071610.2.1 & 53 & 3 & 3 & 1 & 1 & 12.7 & 39.52 \\
\hline Solyc01g111060.2.1 & 53 & 2 & 1 & 2 & 1 & 9.7 & 53.42 \\
\hline Solyc12g036790.1.1 & 53 & 1 & 1 & 1 & 1 & 9.1 & 52.87 \\
\hline Solyc02g067080.2.1 & 53 & 2 & 2 & 2 & 2 & 8.6 & 40 \\
\hline Solyc01g111710.2.1 & 53 & 2 & 2 & 2 & 2 & 7.4 & 36.84 \\
\hline Solyc01g102660.2.1 & 53 & 1 & 1 & 1 & 1 & 6.3 & 52.56 \\
\hline Solyc06g066830.2.1 & 53 & 1 & 1 & 1 & 1 & 6.1 & 53.02 \\
\hline Solyc03g113220.2.1 & 53 & 1 & 1 & 1 & 1 & 5.6 & 53.38 \\
\hline Solyc02g021560.2.1 & 53 & 1 & 1 & 1 & 1 & 5.3 & 52.91 \\
\hline Solyc02g083710.2.1 & 53 & 1 & 1 & 1 & 1 & 4.2 & 52.88 \\
\hline Solyc10g076510.1.1 & 53 & 1 & 1 & 1 & 1 & 2.7 & 52.54 \\
\hline Solyc05g052150.2.1 & 52 & 1 & 1 & 1 & 1 & 17.2 & 52.47 \\
\hline Solyc11g073250.1.1 & 52 & 1 & 1 & 1 & 1 & 15.5 & 52.46 \\
\hline Solyc03g082600.2.1 & 52 & 1 & 1 & 1 & 1 & 8.4 & 51.91 \\
\hline Solyc12g096300.1.1 & 52 & 2 & 2 & 1 & 1 & 6 & 52.04 \\
\hline Solyc08g006040.2.1 & 52 & 1 & 1 & 1 & 1 & 6 & 51.6 \\
\hline Solyc03g117940.2.1 & 52 & 1 & 1 & 1 & 1 & 5.2 & 52.41 \\
\hline Solyc02g090210.2.1 & 52 & 1 & 1 & 1 & 1 & 4.6 & 51.66 \\
\hline Solyc07g055210.2.1 & 52 & 1 & 1 & 1 & 1 & 4.2 & 51.72 \\
\hline
\end{tabular}


Supplemental Table 2. Continued.

\begin{tabular}{|c|c|c|c|c|c|c|c|}
\hline Accession $^{y}$ & $\begin{array}{l}\text { Protein } \\
\text { score }^{\mathrm{x}}\end{array}$ & $\begin{array}{c}\text { Total } \\
\text { matches (no.) }\end{array}$ & $\begin{array}{c}\text { Unique } \\
\text { matches (no.)v }\end{array}$ & $\begin{array}{c}\text { Total } \\
\text { sequences }(\text { no. })^{\mathrm{u}}\end{array}$ & $\begin{array}{c}\text { Unique } \\
\text { sequences (no.) }\end{array}$ & $\begin{array}{c}\text { Protein } \\
\text { coverage }(\%)^{\mathrm{s}}\end{array}$ & $\begin{array}{c}\text { Highest } \\
\text { peptide score }\end{array}$ \\
\hline $\begin{array}{l}\text { Solyc01g099150.2.1 } \\
\end{array}$ & 52 & 2 & 2 & 2 & 2 & 3.5 & 41.9 \\
\hline Solyc03g097910.2.1 & 52 & 1 & 1 & 1 & 1 & 3.5 & 51.62 \\
\hline Solyc03g119170.2.1 & 52 & 2 & 2 & 1 & 1 & 3.4 & 39.36 \\
\hline Solyc08g081320.2.1 & 52 & 1 & 1 & 1 & 1 & 2.1 & 52.03 \\
\hline Solyc01g049680.2.1 & 51 & 2 & 1 & 2 & 1 & 15.6 & 51.23 \\
\hline Solyc03g025800.2.1 & 51 & 1 & 1 & 1 & 1 & 14.8 & 50.7 \\
\hline Solyc09g005500.2.1 & 51 & 1 & 1 & 1 & 1 & 13.2 & 51.17 \\
\hline Solyc06g065970.1.1 & 51 & 1 & 1 & 1 & 1 & 12.7 & 50.87 \\
\hline Solyc03g097900.2.1 & 51 & 2 & 2 & 2 & 2 & 11.1 & 46.41 \\
\hline Solyc03g006680.2.1 & 51 & 2 & 2 & 2 & 2 & 10.6 & 49.24 \\
\hline Solyc09g090040.2.1 & 51 & 1 & 1 & 1 & 1 & 7 & 50.87 \\
\hline Solyc07g042570.2.1 & 51 & 1 & 1 & 1 & 1 & 6.8 & 50.95 \\
\hline Solyc11g011330.1.1 & 51 & 1 & 1 & 1 & 1 & 5.9 & 51.23 \\
\hline Solyc 10g005060.2.1 & 51 & 1 & 1 & 1 & 1 & 4.7 & 50.9 \\
\hline Solyc12g011160.1.1 & 51 & 1 & 1 & 1 & 1 & 4.2 & 51.45 \\
\hline Solyc02g079220.2.1 & 51 & 1 & 1 & 1 & 1 & 3.8 & 51.34 \\
\hline Solyc03g121910.1.1 & 51 & 1 & 1 & 1 & 1 & 3.5 & 50.79 \\
\hline Solyc11g039830.1.1 & 51 & 1 & 1 & 1 & 1 & 1.9 & 50.93 \\
\hline Solyc09g010100.2.1 & 50 & 3 & 2 & 3 & 2 & 22.7 & 32.07 \\
\hline Solyc03g113580.1.1 & 50 & 3 & 2 & 3 & 2 & 18.4 & 37.81 \\
\hline Solyc01g079610.2.1 & 50 & 2 & 2 & 2 & 2 & 9.3 & 35.83 \\
\hline Solyc02g068130.2.1 & 50 & 1 & 1 & 1 & 1 & 8.8 & 49.63 \\
\hline Solyc03g019690.1.1 & 50 & 1 & 1 & 1 & 1 & 7.8 & 50.21 \\
\hline Solyc08g079830.2.1 & 50 & 1 & 1 & 1 & 1 & 6.4 & 50.12 \\
\hline Solyc03g113030.2.1 & 50 & 1 & 1 & 1 & 1 & 5.6 & 50.13 \\
\hline Solyc06g054250.2.1 & 50 & 1 & 1 & 1 & 1 & 5.3 & 49.86 \\
\hline Solyc10g086150.1.1 & 50 & 2 & 2 & 1 & 1 & 4.5 & 40.34 \\
\hline Solyc12g096220.1.1 & 50 & 3 & 3 & 3 & 3 & 4.3 & 35.45 \\
\hline Solyc04g008760.1.1 & 50 & 1 & 1 & 1 & 1 & 4.2 & 49.72 \\
\hline Solyc03g120720.2.1 & 50 & 1 & 1 & 1 & 1 & 3.2 & 49.57 \\
\hline Solyc01g008080.2.1 & 49 & 2 & 1 & 2 & 1 & 34.9 & 37.91 \\
\hline Solyc09g057650.2.1 & 49 & 2 & 2 & 2 & 2 & 13.1 & 42.98 \\
\hline Solyc07g047800.2.1 & 49 & 2 & 2 & 2 & 2 & 11.3 & 45.3 \\
\hline Solyc01g022750.2.1 & 49 & 1 & 1 & 1 & 1 & 9.8 & 49.33 \\
\hline Solyc06g067940.2.1 & 49 & 1 & 1 & 1 & 1 & 8.5 & 48.64 \\
\hline Solyc08g077900.2.1 & 49 & 1 & 1 & 1 & 1 & 5.1 & 49.45 \\
\hline Solyc07g062070.2.1 & 49 & 1 & 1 & 1 & 1 & 4.8 & 48.74 \\
\hline Solyc03g120880.2.1 & 49 & 1 & 1 & 1 & 1 & 3.8 & 48.59 \\
\hline Solyc01g109350.2.1 & 49 & 1 & 1 & 1 & 1 & 2.8 & 49.02 \\
\hline Solyc03g113800.2.1 & 49 & 1 & 1 & 1 & 1 & 2.6 & 48.85 \\
\hline Solyc02g085350.2.1 & 49 & 1 & 1 & 1 & 1 & 2.2 & 48.83 \\
\hline Solyc00g094530.1.1 & 48 & 1 & 1 & 1 & 1 & 14.7 & 47.53 \\
\hline Solyc07g008350.2.1 & 48 & 2 & 2 & 2 & 2 & 10.9 & 40.33 \\
\hline Solyc10g084700.1.1 & 48 & 1 & 1 & 1 & 1 & 7.9 & 47.62 \\
\hline Solyc02g092730.2.1 & 48 & 1 & 1 & 1 & 1 & 5.5 & 48.09 \\
\hline Solyc02g082250.2.1 & 48 & 1 & 1 & 1 & 1 & 4.4 & 48.12 \\
\hline Solyc08g029160.1.1 & 47 & 2 & 1 & 1 & 1 & 15 & 34.5 \\
\hline Solyc05g026050.2.1 & 47 & 2 & 2 & 2 & 2 & 11.5 & 36.49 \\
\hline Solyc09g010440.2.1 & 47 & 1 & 1 & 1 & 1 & 11.5 & 46.78 \\
\hline Solyc10g081440.1.1 & 47 & 2 & 1 & 2 & 1 & 10.8 & 41.94 \\
\hline Solyc02g088260.2.1 & 47 & 2 & 2 & 2 & 2 & 9.1 & 43.59 \\
\hline Solyc01g010750.2.1 & 47 & 2 & 2 & 2 & 2 & 8.3 & 39.64 \\
\hline Solyc11g039840.1.1 & 47 & 1 & 1 & 1 & 1 & 7.2 & 47.24 \\
\hline Solyc05g053140.2.1 & 47 & 2 & 1 & 2 & 1 & 6.5 & 40.16 \\
\hline Solyc01g007740.2.1 & 47 & 1 & 1 & 1 & 1 & 6 & 47.01 \\
\hline Solyc02g021420.2.1 & 47 & 2 & 2 & 2 & 2 & 3 & 36.58 \\
\hline Solyc07g042520.2.1 & 47 & 2 & 1 & 2 & 1 & 3 & 39.98 \\
\hline
\end{tabular}


Supplemental Table 2. Continued.

\begin{tabular}{|c|c|c|c|c|c|c|c|}
\hline Accession $^{y}$ & $\begin{array}{l}\text { Protein } \\
\text { score }^{\mathrm{x}}\end{array}$ & $\begin{array}{c}\text { Total } \\
\text { matches (no.) }\end{array}$ & $\begin{array}{c}\text { Unique } \\
\text { matches (no.) }\end{array}$ & $\begin{array}{c}\text { Total } \\
\text { sequences (no. })^{\mathrm{u}}\end{array}$ & $\begin{array}{c}\text { Unique } \\
\text { sequences (no.) }\end{array}$ & $\begin{array}{c}\text { Protein } \\
\text { coverage }(\%)^{\mathrm{s}}\end{array}$ & $\begin{array}{c}\text { Highest } \\
\text { peptide score }\end{array}$ \\
\hline $\begin{array}{l}\text { Solyc09g091000.2.1 } \\
\end{array}$ & 46 & 2 & 2 & 2 & 2 & 22.6 & 38.19 \\
\hline Solyc02g071150.2.1 & 46 & 2 & 1 & 2 & 1 & 17.2 & 46.05 \\
\hline Solyc09g010400.2.1 & 46 & 1 & 1 & 1 & 1 & 15.9 & 46.07 \\
\hline Solyc06g035870.2.1 & 46 & 1 & 1 & 1 & 1 & 8.3 & 46.06 \\
\hline Solyc01g106320.2.1 & 46 & 1 & 1 & 1 & 1 & 6.9 & 45.97 \\
\hline Solyc06g082800.2.1 & 46 & 1 & 1 & 1 & 1 & 5.4 & 45.86 \\
\hline Solyc08g008530.1.1 & 46 & 1 & 1 & 1 & 1 & 5.1 & 46.29 \\
\hline Solyc01g088510.2.1 & 46 & 1 & 1 & 1 & 1 & 3.7 & 46.14 \\
\hline Solyc02g079410.2.1 & 45 & 2 & 1 & 2 & 1 & 13.7 & 34.33 \\
\hline Solyc01g066840.2.1 & 45 & 1 & 1 & 1 & 1 & 13.4 & 45.3 \\
\hline Solyc11g066150.1.1 & 45 & 2 & 2 & 2 & 2 & 13 & 37.13 \\
\hline Solyc02g085040.2.1 & 45 & 1 & 1 & 1 & 1 & 11.1 & 44.66 \\
\hline Solyc03g062890.2.1 & 45 & 1 & 1 & 1 & 1 & 8.3 & 44.71 \\
\hline Solyc02g070640.2.1 & 45 & 1 & 1 & 1 & 1 & 7.9 & 44.58 \\
\hline Solyc03g115760.2.1 & 45 & 1 & 1 & 1 & 1 & 5 & 44.92 \\
\hline Solyc02g081400.2.1 & 45 & 1 & 1 & 1 & 1 & 4.1 & 45.45 \\
\hline Solyc10g079500.1.1 & 45 & 1 & 1 & 1 & 1 & 3 & 45.25 \\
\hline Solyc11g040370.1.1 & 45 & 1 & 1 & 1 & 1 & 2.4 & 45.45 \\
\hline Solyc01g102700.2.1 & 45 & 1 & 1 & 1 & 1 & 1.9 & 45.3 \\
\hline Solyc01g091220.2.1 & 44 & 3 & 3 & 3 & 3 & 16.6 & 32.29 \\
\hline Solyc09g082650.2.1 & 44 & 2 & 2 & 2 & 2 & 11.6 & 31.96 \\
\hline Solyc02g031740.2.1 & 44 & 1 & 1 & 1 & 1 & 7.1 & 43.62 \\
\hline Solyc03g116170.2.1 & 44 & 1 & 1 & 1 & 1 & 6.7 & 44.17 \\
\hline Solyc11g073280.1.1 & 44 & 1 & 1 & 1 & 1 & 6.4 & 44.25 \\
\hline Solyc01g101240.2.1 & 44 & 2 & 2 & 2 & 2 & 5.3 & 32.83 \\
\hline Solyc03g123830.2.1 & 44 & 2 & 2 & 2 & 2 & 4.3 & 36.19 \\
\hline Solyc01g112280.2.1 & 44 & 1 & 1 & 1 & 1 & 2.9 & 44.37 \\
\hline Solyc08g014000.2.1 & 44 & 1 & 1 & 1 & 1 & 2.1 & 43.59 \\
\hline Solyc03g114170.2.1 & 43 & 1 & 1 & 1 & 1 & 40 & 42.88 \\
\hline Solyc05g043430.2.1 & 43 & 2 & 2 & 2 & 2 & 15.5 & 34.33 \\
\hline Solyc04g071620.2.1 & 43 & 2 & 2 & 2 & 2 & 12.5 & 34.2 \\
\hline Solyc07g062570.2.1 & 43 & 1 & 1 & 1 & 1 & 9.8 & 42.97 \\
\hline Solyc03g116590.2.1 & 43 & 1 & 1 & 1 & 1 & 9.7 & 43.44 \\
\hline Solyc02g078040.2.1 & 43 & 1 & 1 & 1 & 1 & 6.6 & 42.8 \\
\hline Solyc01g111660.2.1 & 43 & 1 & 1 & 1 & 1 & 6 & 42.66 \\
\hline Solyc01g105370.2.1 & 43 & 1 & 1 & 1 & 1 & 5.3 & 42.61 \\
\hline Solyc09g011920.2.1 & 43 & 1 & 1 & 1 & 1 & 5.2 & 43.32 \\
\hline Solyc03g121580.2.1 & 43 & 1 & 1 & 1 & 1 & 4.3 & 42.85 \\
\hline Solyc02g090090.2.1 & 43 & 1 & 1 & 1 & 1 & 3.4 & 43.13 \\
\hline Solyc01g096040.2.1 & 43 & 1 & 1 & 1 & 1 & 3.3 & 43.24 \\
\hline Solyc07g065680.2.1 & 43 & 1 & 1 & 1 & 1 & 3.1 & 43.27 \\
\hline Solyc02g092670.1.1 & 43 & 1 & 1 & 1 & 1 & 2.4 & 43.11 \\
\hline Solyc06g008170.2.1 & 42 & 1 & 1 & 1 & 1 & 12.9 & 42.14 \\
\hline Solyc05g053670.2.1 & 42 & 2 & 2 & 2 & 2 & 12.1 & 34.75 \\
\hline Solyc10g007070.2.1 & 42 & 2 & 2 & 2 & 2 & 11.3 & 37.16 \\
\hline Solyc08g066740.2.1 & 42 & 1 & 1 & 1 & 1 & 10.5 & 41.71 \\
\hline Solyc06g067960.2.1 & 42 & 1 & 1 & 1 & 1 & 10 & 42.18 \\
\hline Solyc03g007660.2.1 & 42 & 1 & 1 & 1 & 1 & 8.6 & 41.86 \\
\hline Solyc02g069100.2.1 & 42 & 1 & 1 & 1 & 1 & 8.2 & 41.54 \\
\hline Solyc02g068500.2.1 & 42 & 1 & 1 & 1 & 1 & 6.7 & 41.57 \\
\hline Solyc03g080050.2.1 & 42 & 2 & 2 & 2 & 2 & 6.6 & 30.48 \\
\hline Solyc07g032250.2.1 & 42 & 1 & 1 & 1 & 1 & 5.6 & 41.82 \\
\hline Solyc03g007670.2.1 & 42 & 1 & 1 & 1 & 1 & 5.4 & 41.56 \\
\hline Solyc07g064810.2.1 & 42 & 1 & 1 & 1 & 1 & 2.7 & 42.11 \\
\hline Solyc01g097990.2.1 & 41 & 1 & 1 & 1 & 1 & 23.1 & 41.29 \\
\hline Solyc06g073900.2.1 & 41 & 1 & 1 & 1 & 1 & 18.2 & 41.04 \\
\hline Solyc05g055280.1.1 & 41 & 1 & 1 & 1 & 1 & 15.3 & 40.59 \\
\hline
\end{tabular}


Supplemental Table 2. Continued.

\begin{tabular}{|c|c|c|c|c|c|c|c|}
\hline Accession $^{y}$ & $\begin{array}{l}\text { Protein } \\
\text { score }^{\mathrm{x}}\end{array}$ & $\begin{array}{c}\text { Total } \\
\text { matches (no.) }\end{array}$ & $\begin{array}{c}\text { Unique } \\
\text { matches (no.) }^{\mathrm{v}}\end{array}$ & $\begin{array}{c}\text { Total } \\
\text { sequences }(\text { no. })^{\mathrm{u}}\end{array}$ & $\begin{array}{c}\text { Unique } \\
\text { sequences (no.) }^{\mathrm{t}}\end{array}$ & $\begin{array}{c}\text { Protein } \\
\text { coverage }(\%)^{\mathrm{s}}\end{array}$ & $\begin{array}{c}\text { Highest } \\
\text { peptide score }\end{array}$ \\
\hline Solyc11g012110.1.1 & 41 & 2 & 2 & 2 & 2 & 12.7 & 38.8 \\
\hline Solyc08g082700.2.1 & 41 & 1 & 1 & 1 & 1 & 6.4 & 41.44 \\
\hline Solyc01g108860.2.1 & 41 & 1 & 1 & 1 & 1 & 5.4 & 40.83 \\
\hline Solyc03g111840.2.1 & 41 & 1 & 1 & 1 & 1 & 5.1 & 41.41 \\
\hline Solyc12g099660.1.1 & 41 & 2 & 2 & 2 & 2 & 4.9 & 31.74 \\
\hline Solyc09g098280.2.1 & 41 & 1 & 1 & 1 & 1 & 4.1 & 41.2 \\
\hline Solyc04g081740.2.1 & 41 & 1 & 1 & 1 & 1 & 3.9 & 41.4 \\
\hline Solyc08g076990.2.1 & 41 & 1 & 1 & 1 & 1 & 3 & 40.72 \\
\hline Solyc04g072830.2.1 & 41 & 2 & 2 & 1 & 1 & 1 & 30.11 \\
\hline Solyc03g020010.1.1 & 40 & 3 & 2 & 3 & 2 & 24.9 & 33.32 \\
\hline Solyc03g020010.1.1 & 40 & 3 & 2 & 3 & 2 & 24.9 & 29.48 \\
\hline Solyc10g086090.1.1 & 40 & 1 & 1 & 1 & 1 & 14.7 & 40.41 \\
\hline Solyc08g016420.2.1 & 40 & 1 & 1 & 1 & 1 & 10 & 39.99 \\
\hline Solyc01g099670.2.1 & 40 & 1 & 1 & 1 & 1 & 8.2 & 39.85 \\
\hline Solyc03g083610.2.1 & 40 & 1 & 1 & 1 & 1 & 7.2 & 40.27 \\
\hline Solyc04g008280.2.1 & 40 & 1 & 1 & 1 & 1 & 7.2 & 40.17 \\
\hline Solyc09g011630.2.1 & 40 & 1 & 1 & 1 & 1 & 6.4 & 39.8 \\
\hline Solyc01g098550.2.1 & 40 & 1 & 1 & 1 & 1 & 6.1 & 40.47 \\
\hline Solyc03g007200.1.1 & 40 & 1 & 1 & 1 & 1 & 5.1 & 40.09 \\
\hline Solyc06g060420.2.1 & 40 & 1 & 1 & 1 & 1 & 4.7 & 40.37 \\
\hline Solyc12g011270.1.1 & 40 & 1 & 1 & 1 & 1 & 4.6 & 40.05 \\
\hline Solyc11g011920.1.1 & 40 & 2 & 1 & 2 & 1 & 4.4 & 39.62 \\
\hline Solyc11g011920.1.1 & 40 & 2 & 1 & 2 & 1 & 4.4 & 24.86 \\
\hline Solyc02g091970.2.1 & 40 & 1 & 1 & 1 & 1 & 4.2 & 39.64 \\
\hline Solyc11g006350.1.1 & 40 & 1 & 1 & 1 & 1 & 4 & 40.2 \\
\hline Solyc05g009030.2.1 & 40 & 1 & 1 & 1 & 1 & 3.7 & 40.13 \\
\hline Solyc05g018700.2.1 & 40 & 1 & 1 & 1 & 1 & 3.2 & 40.02 \\
\hline Solyc03g111310.2.1 & 40 & 1 & 1 & 1 & 1 & 3.1 & 39.5 \\
\hline Solyc03g005730.2.1 & 40 & 1 & 1 & 1 & 1 & 2.8 & 40.4 \\
\hline Solyc08g075390.2.1 & 40 & 1 & 1 & 1 & 1 & 2.4 & 39.51 \\
\hline Solyc03g098280.2.1 & 40 & 1 & 1 & 1 & 1 & 1.7 & 40.11 \\
\hline Solyc01g009100.2.1 & 39 & 1 & 1 & 1 & 1 & 14.3 & 38.66 \\
\hline Solyc01g098000.2.1 & 39 & 1 & 1 & 1 & 1 & 13.3 & 39.4 \\
\hline Solyc08g075690.2.1 & 39 & 1 & 1 & 1 & 1 & 13.3 & 38.9 \\
\hline Solyc09g065830.2.1 & 39 & 2 & 1 & 2 & 1 & 10.2 & 25.34 \\
\hline Solyc09g065830.2.1 & 39 & 2 & 1 & 2 & 1 & 10.2 & 32.32 \\
\hline Solyc03g098730.1.1 & 39 & 1 & 1 & 1 & 1 & 7.3 & 38.6 \\
\hline Solyc02g062540.2.1 & 39 & 1 & 1 & 1 & 1 & 7 & 38.64 \\
\hline Solyc04g055160.2.1 & 39 & 1 & 1 & 1 & 1 & 5.5 & 39.18 \\
\hline Solyc03g112650.2.1 & 39 & 1 & 1 & 1 & 1 & 5 & 38.63 \\
\hline Solyc02g014310.2.1 & 39 & 2 & 2 & 2 & 2 & 3.8 & 32.42 \\
\hline Solyc12g006980.1.1 & 39 & 1 & 1 & 1 & 1 & 3.6 & 38.91 \\
\hline Solyc06g075340.2.1 & 39 & 1 & 1 & 1 & 1 & 1.2 & 39.25 \\
\hline Solyc03g111230.2.1 & 38 & 1 & 1 & 1 & 1 & 14.1 & 38.21 \\
\hline Solyc03g043960.2.1 & 38 & 1 & 1 & 1 & 1 & 11.4 & 38.23 \\
\hline Solyc01g066590.2.1 & 38 & 1 & 1 & 1 & 1 & 10.1 & 38.5 \\
\hline Solyc12g099200.1.1 & 38 & 1 & 1 & 1 & 1 & 9.4 & 37.73 \\
\hline Solyc01g110390.2.1 & 38 & 1 & 1 & 1 & 1 & 9.2 & 38.02 \\
\hline Solyc02g088690.2.1 & 38 & 1 & 1 & 1 & 1 & 8.5 & 37.51 \\
\hline Solyc01g097350.2.1 & 38 & 1 & 1 & 1 & 1 & 8 & 38.46 \\
\hline Solyc08g082430.2.1 & 38 & 2 & 1 & 2 & 1 & 7.6 & 29.79 \\
\hline Solyc08g062820.2.1 & 38 & 1 & 1 & 1 & 1 & 7.5 & 37.58 \\
\hline Solyc09g075670.1.1 & 38 & 1 & 1 & 1 & 1 & 6 & 38.1 \\
\hline Solyc02g088460.2.1 & 38 & 1 & 1 & 1 & 1 & 5.4 & 38.29 \\
\hline Solyc01g007910.2.1 & 38 & 1 & 1 & 1 & 1 & 4.5 & 38.17 \\
\hline Solyc07g043310.2.1 & 38 & 2 & 2 & 1 & 1 & 2.7 & 31.88 \\
\hline Solyc08g082010.2.1 & 38 & 1 & 1 & 1 & 1 & 1.1 & 37.85 \\
\hline
\end{tabular}


Supplemental Table 2. Continued.

\begin{tabular}{|c|c|c|c|c|c|c|c|}
\hline Accession $^{y}$ & $\begin{array}{l}\text { Protein } \\
\text { score }^{\mathrm{x}}\end{array}$ & $\begin{array}{c}\text { Total } \\
\text { matches (no.) }\end{array}$ & $\begin{array}{c}\text { Unique } \\
\text { matches (no.) }^{\mathrm{v}}\end{array}$ & $\begin{array}{c}\text { Total } \\
\text { sequences }(\text { no. })^{\mathrm{u}}\end{array}$ & $\begin{array}{c}\text { Unique } \\
\text { sequences (no.) }^{\mathrm{t}}\end{array}$ & $\begin{array}{c}\text { Protein } \\
\text { coverage }(\%)^{\mathrm{s}}\end{array}$ & $\begin{array}{c}\text { Highest } \\
\text { peptide score }\end{array}$ \\
\hline $\begin{array}{l}\text { Solyc11g068400.1.1 } \\
\end{array}$ & 37 & 1 & 1 & 1 & 1 & 15.3 & 37.46 \\
\hline Solyc07g063680.2.1 & 37 & 2 & 1 & 2 & 1 & 14.9 & 29.18 \\
\hline Solyc10g008190.2.1 & 37 & 1 & 1 & 1 & 1 & 10.4 & 36.76 \\
\hline Solyc06g071720.1.1 & 37 & 1 & 1 & 1 & 1 & 10.1 & 37.48 \\
\hline Solyc09g075810.2.1 & 37 & 1 & 1 & 1 & 1 & 8.7 & 36.71 \\
\hline Solyc04g071900.2.1 & 37 & 3 & 2 & 2 & 1 & 7.7 & 30.84 \\
\hline Solyc07g009160.2.1 & 37 & 1 & 1 & 1 & 1 & 6.4 & 36.66 \\
\hline Solyc04g016360.2.1 & 37 & 1 & 1 & 1 & 1 & 6 & 37.28 \\
\hline Solyc03g121710.2.1 & 37 & 1 & 1 & 1 & 1 & 5.9 & 37.06 \\
\hline Solyc08g080940.2.1 & 37 & 1 & 1 & 1 & 1 & 5.4 & 36.78 \\
\hline Solyc03g121500.2.1 & 37 & 1 & 1 & 1 & 1 & 4.8 & 37.43 \\
\hline Solyc02g093310.2.1 & 37 & 1 & 1 & 1 & 1 & 4.4 & 37.05 \\
\hline Solyc03g120450.2.1 & 37 & 1 & 1 & 1 & 1 & 4.1 & 36.83 \\
\hline Solyc08g029000.2.1 & 37 & 2 & 1 & 2 & 1 & 3.7 & 30.64 \\
\hline Solyc01g111440.2.1 & 37 & 1 & 1 & 1 & 1 & 3.4 & 36.57 \\
\hline Solyc04g076090.2.1 & 37 & 1 & 1 & 1 & 1 & 3.2 & 36.93 \\
\hline Solyc03g117600.2.1 & 37 & 1 & 1 & 1 & 1 & 3 & 37.42 \\
\hline Solyc01g091190.2.1 & 37 & 1 & 1 & 1 & 1 & 2.7 & 37.48 \\
\hline Solyc01g008310.2.1 & 37 & 1 & 1 & 1 & 1 & 2.4 & 36.68 \\
\hline Solyc11g040390.1.1 & 37 & 1 & 1 & 1 & 1 & 2.2 & 37 \\
\hline Solyc07g053650.2.1 & 37 & 1 & 1 & 1 & 1 & 1.8 & 37.37 \\
\hline Solyc02g094200.2.1 & 36 & 1 & 1 & 1 & 1 & 23.6 & 35.88 \\
\hline Solyc03g113730.2.1 & 36 & 1 & 1 & 1 & 1 & 14.4 & 36.23 \\
\hline Solyc04g010240.2.1 & 36 & 1 & 1 & 1 & 1 & 10.6 & 35.89 \\
\hline Solyc12g015690.1.1 & 36 & 1 & 1 & 1 & 1 & 10.1 & 36.22 \\
\hline Solyc01g066860.2.1 & 36 & 1 & 1 & 1 & 1 & 9.7 & 36.46 \\
\hline Solyc09g005640.2.1 & 36 & 1 & 1 & 1 & 1 & 8.9 & 36.37 \\
\hline Solyc10g076350.1.1 & 36 & 1 & 1 & 1 & 1 & 8.8 & 35.89 \\
\hline Solyc12g013900.1.1 & 36 & 2 & 2 & 2 & 2 & 8.2 & 31.39 \\
\hline Solyc01g079880.2.1 & 36 & 1 & 1 & 1 & 1 & 5.5 & 35.61 \\
\hline Solyc01g094970.2.1 & 36 & 1 & 1 & 1 & 1 & 3.9 & 36.27 \\
\hline Solyc12g096190.1.1 & 36 & 1 & 1 & 1 & 1 & 3.9 & 35.62 \\
\hline Solyc04g079440.2.1 & 36 & 1 & 1 & 1 & 1 & 3.6 & 35.55 \\
\hline Solyc03g121700.2.1 & 36 & 1 & 1 & 1 & 1 & 3.5 & 36.36 \\
\hline Solyc06g083730.2.1 & 36 & 1 & 1 & 1 & 1 & 3.5 & 36.16 \\
\hline Solyc07g047790.2.1 & 36 & 1 & 1 & 1 & 1 & 3.3 & 35.93 \\
\hline Solyc04g009200.2.1 & 36 & 1 & 1 & 1 & 1 & 2.9 & 35.8 \\
\hline Solyc03g082940.2.1 & 36 & 1 & 1 & 1 & 1 & 2.9 & 35.72 \\
\hline Solyc09g007640.2.1 & 36 & 1 & 1 & 1 & 1 & 2.8 & 36.29 \\
\hline Solyc03g117280.2.1 & 36 & 1 & 1 & 1 & 1 & 2.6 & 35.7 \\
\hline Solyc01g103480.2.1 & 36 & 1 & 1 & 1 & 1 & 2.3 & 36.16 \\
\hline Solyc11g068510.1.1 & 35 & 1 & 1 & 1 & 1 & 26.3 & 35.08 \\
\hline Solyc01g081270.2.1 & 35 & 1 & 1 & 1 & 1 & 6.3 & 35.18 \\
\hline Solyc11g068540.1.1 & 35 & 1 & 1 & 1 & 1 & 6 & 34.98 \\
\hline Solyc08g006730.1.1 & 35 & 1 & 1 & 1 & 1 & 5.8 & 35.46 \\
\hline Solyc03g117810.2.1 & 35 & 1 & 1 & 1 & 1 & 5.3 & 35.18 \\
\hline Solyc01g073640.2.1 & 35 & 1 & 1 & 1 & 1 & 5 & 35.42 \\
\hline Solyc02g071330.2.1 & 35 & 1 & 1 & 1 & 1 & 5 & 35.33 \\
\hline Solyc11g005620.1.1 & 35 & 1 & 1 & 1 & 1 & 4.9 & 34.8 \\
\hline Solyc04g072560.2.1 & 35 & 1 & 1 & 1 & 1 & 4.7 & 34.95 \\
\hline Solyc09g082990.2.1 & 35 & 1 & 1 & 1 & 1 & 4.3 & 35.08 \\
\hline Solyc05g010300.2.1 & 35 & 1 & 1 & 1 & 1 & 4.1 & 35.08 \\
\hline Solyc01g105810.2.1 & 35 & 1 & 1 & 1 & 1 & 3.1 & 35.14 \\
\hline Solyc08g065490.2.1 & 35 & 1 & 1 & 1 & 1 & 2.9 & 34.62 \\
\hline Solyc11g011020.1.1 & 35 & 1 & 1 & 1 & 1 & 2.8 & 34.88 \\
\hline Solyc01g100390.2.1 & 35 & 1 & 1 & 1 & 1 & 2.1 & 35.01 \\
\hline Solyc03g113490.2.1 & 35 & 1 & 1 & 1 & 1 & 2 & 35.22 \\
\hline
\end{tabular}


Supplemental Table 2. Continued.

\begin{tabular}{|c|c|c|c|c|c|c|c|}
\hline Accession $^{y}$ & $\begin{array}{l}\text { Protein } \\
\text { score }^{\mathrm{x}}\end{array}$ & $\begin{array}{c}\text { Total } \\
\text { matches (no.) }\end{array}$ & $\begin{array}{c}\text { Unique } \\
\text { matches (no.) }^{\mathrm{v}}\end{array}$ & $\begin{array}{c}\text { Total } \\
\text { sequences }(\text { no. })^{\mathrm{u}}\end{array}$ & $\begin{array}{c}\text { Unique } \\
\text { sequences (no.) }^{\mathrm{t}}\end{array}$ & $\begin{array}{c}\text { Protein } \\
\text { coverage }(\%)^{\mathrm{s}}\end{array}$ & $\begin{array}{c}\text { Highest } \\
\text { peptide score }\end{array}$ \\
\hline Solyc02g068300.2.1 & 35 & 1 & 1 & 1 & 1 & 1.7 & 34.98 \\
\hline Solyc02g081270.2.1 & 35 & 1 & 1 & 1 & 1 & 1.6 & 35.14 \\
\hline Solyc02g094440.2.1 & 34 & 1 & 1 & 1 & 1 & 12.5 & 34.17 \\
\hline Solyc09g005720.2.1 & 34 & 1 & 1 & 1 & 1 & 8.5 & 34.05 \\
\hline Solyc06g069040.2.1 & 34 & 1 & 1 & 1 & 1 & 6.2 & 33.7 \\
\hline Solyc06g072220.1.1 & 34 & 1 & 1 & 1 & 1 & 5.7 & 34.16 \\
\hline Solyc01g096450.2.1 & 34 & 2 & 1 & 2 & 1 & 5.4 & 26.81 \\
\hline Solyc01g096450.2.1 & 34 & 2 & 1 & 2 & 1 & 5.4 & 33.58 \\
\hline Solyc02g081140.2.1 & 34 & 1 & 1 & 1 & 1 & 5.3 & 34.15 \\
\hline Solyc01g105410.2.1 & 34 & 1 & 1 & 1 & 1 & 4.7 & 34.49 \\
\hline Solyc07g062480.1.1 & 34 & 1 & 1 & 1 & 1 & 4.7 & 34.04 \\
\hline Solyc12g005200.1.1 & 34 & 1 & 1 & 1 & 1 & 4.2 & 33.64 \\
\hline Solyc07g017900.2.1 & 34 & 1 & 1 & 1 & 1 & 4.1 & 33.68 \\
\hline Solyc02g087240.2.1 & 34 & 1 & 1 & 1 & 1 & 3.3 & 34.21 \\
\hline Solyc04g063280.2.1 & 34 & 1 & 1 & 1 & 1 & 3 & 34.09 \\
\hline Solyc09g083080.2.1 & 34 & 1 & 1 & 1 & 1 & 2.9 & 34.46 \\
\hline Solyc08g041890.2.1 & 34 & 1 & 1 & 1 & 1 & 2.3 & 34.02 \\
\hline Solyc01g104850.2.1 & 34 & 1 & 1 & 1 & 1 & 2.1 & 34.35 \\
\hline Solyc07g008240.2.1 & 33 & 2 & 1 & 2 & 1 & 15.8 & 31.85 \\
\hline Solyc11g066130.1.1 & 33 & 3 & 1 & 3 & 1 & 12.7 & 33.05 \\
\hline Solyc06g075810.2.1 & 33 & 1 & 1 & 1 & 1 & 11.2 & 33.46 \\
\hline Solyc03g112770.2.1 & 33 & 1 & 1 & 1 & 1 & 10.4 & 32.59 \\
\hline Solyc03g121330.2.1 & 33 & 1 & 1 & 1 & 1 & 9.1 & 33.29 \\
\hline Solyc07g026650.2.1 & 33 & 1 & 1 & 1 & 1 & 8 & 33.2 \\
\hline Solyc09g065270.2.1 & 33 & 1 & 1 & 1 & 1 & 7.5 & 33.09 \\
\hline Solyc12g096650.1.1 & 33 & 1 & 1 & 1 & 1 & 7 & 32.88 \\
\hline Solyc09g011570.2.1 & 33 & 1 & 1 & 1 & 1 & 6.7 & 32.68 \\
\hline Solyc02g032040.1.1 & 33 & 1 & 1 & 1 & 1 & 6.3 & 33.27 \\
\hline Solyc04g014820.2.1 & 33 & 1 & 1 & 1 & 1 & 6 & 32.99 \\
\hline Solyc01g058390.2.1 & 33 & 1 & 1 & 1 & 1 & 5.6 & 33.02 \\
\hline Solyc01g095000.2.1 & 33 & 1 & 1 & 1 & 1 & 5.3 & 32.53 \\
\hline Solyc02g079210.2.1 & 33 & 1 & 1 & 1 & 1 & 4.8 & 33.13 \\
\hline Solyc01g087540.2.1 & 33 & 1 & 1 & 1 & 1 & 4.4 & 33.2 \\
\hline Solyc07g006830.2.1 & 33 & 1 & 1 & 1 & 1 & 2.4 & 32.71 \\
\hline Solyc04g054470.2.1 & 33 & 1 & 1 & 1 & 1 & 2.3 & 33.24 \\
\hline Solyc08g079970.1.1 & 33 & 1 & 1 & 1 & 1 & 0.8 & 32.86 \\
\hline Solyc12g008590.1.1 & 32 & 1 & 1 & 1 & 1 & 36.7 & 31.8 \\
\hline Solyc04g007760.2.1 & 32 & 2 & 1 & 2 & 1 & 14.4 & 32.46 \\
\hline Solyc05g052140.2.1 & 32 & 1 & 1 & 1 & 1 & 13.7 & 32.22 \\
\hline Solyc10g047650.1.1 & 32 & 1 & 1 & 1 & 1 & 10.6 & 32.29 \\
\hline Solyc03g031600.2.1 & 32 & 1 & 1 & 1 & 1 & 9.2 & 32.24 \\
\hline Solyc06g060850.2.1 & 32 & 1 & 1 & 1 & 1 & 7.8 & 32.03 \\
\hline Solyc01g111230.2.1 & 32 & 1 & 1 & 1 & 1 & 6.6 & 32.06 \\
\hline Solyc04g049710.2.1 & 32 & 1 & 1 & 1 & 1 & 6.4 & 31.7 \\
\hline Solyc06g069890.2.1 & 32 & 1 & 1 & 1 & 1 & 4.2 & 31.61 \\
\hline Solyc08g076620.1.1 & 32 & 1 & 1 & 1 & 1 & 4.1 & 31.97 \\
\hline Solyc10g074590.1.1 & 32 & 1 & 1 & 1 & 1 & 3.8 & 32.34 \\
\hline Solyc02g093830.2.1 & 32 & 1 & 1 & 1 & 1 & 2.3 & 31.91 \\
\hline Solyc03g111180.2.1 & 32 & 1 & 1 & 1 & 1 & 2.1 & 32.45 \\
\hline Solyc01g104680.2.1 & 31 & 2 & 1 & 2 & 1 & 12.2 & 31.15 \\
\hline Solyc01g067730.2.1 & 31 & 1 & 1 & 1 & 1 & 11 & 30.57 \\
\hline Solyc01g009990.2.1 & 31 & 2 & 2 & 2 & 2 & 8.9 & 30.35 \\
\hline Solyc09g010930.2.1 & 31 & 1 & 1 & 1 & 1 & 6.7 & 31.4 \\
\hline Solyc05g005490.2.1 & 31 & 1 & 1 & 1 & 1 & 5.2 & 31.32 \\
\hline Solyc07g048090.1.1 & 31 & 1 & 1 & 1 & 1 & 5.2 & 30.81 \\
\hline Solyc08g067370.1.1 & 31 & 1 & 1 & 1 & 1 & 5.1 & 31.11 \\
\hline Solyc06g069020.2.1 & 31 & 1 & 1 & 1 & 1 & 4.7 & 31.41 \\
\hline
\end{tabular}


Supplemental Table 2. Continued.

\begin{tabular}{|c|c|c|c|c|c|c|c|}
\hline Accession $^{y}$ & $\begin{array}{l}\text { Protein } \\
\text { score }^{\mathrm{x}}\end{array}$ & $\begin{array}{c}\text { Total } \\
\text { matches (no.) }\end{array}$ & $\begin{array}{c}\text { Unique } \\
\text { matches (no.) }\end{array}$ & $\begin{array}{c}\text { Total } \\
\text { sequences (no.) }{ }^{\mathrm{u}}\end{array}$ & $\begin{array}{c}\text { Unique } \\
\text { sequences (no. })^{t}\end{array}$ & $\begin{array}{c}\text { Protein } \\
\text { coverage }(\%)^{\mathrm{s}}\end{array}$ & $\begin{array}{c}\text { Highest } \\
\text { peptide score }\end{array}$ \\
\hline Solyc04g063290.2.1 & 31 & 1 & 1 & 1 & 1 & 4.6 & 30.61 \\
\hline Solyc07g064510.2.1 & 31 & 1 & 1 & 1 & 1 & 3.2 & 30.85 \\
\hline Solyc04g080260.2.1 & 31 & 1 & 1 & 1 & 1 & 3.2 & 30.53 \\
\hline Solyc09g064370.2.1 & 31 & 1 & 1 & 1 & 1 & 3.1 & 30.6 \\
\hline Solyc04g076790.2.1 & 31 & 1 & 1 & 1 & 1 & 2.9 & 31.37 \\
\hline Solyc07g063100.2.1 & 31 & 1 & 1 & 1 & 1 & 2.1 & 30.51 \\
\hline Solyc05g015920.2.1 & 31 & 1 & 1 & 1 & 1 & 1.2 & 31.2 \\
\hline Solyc06g074640.1.1 & 31 & 1 & 1 & 1 & 1 & 1 & 30.52 \\
\hline Solyc03g093360.2.1 & 30 & 2 & 1 & 2 & 1 & 9.5 & 25.26 \\
\hline Solyc07g014730.2.1 & 30 & 1 & 1 & 1 & 1 & 9 & 29.81 \\
\hline Solyc01g007860.2.1 & 30 & 1 & 1 & 1 & 1 & 8.2 & 30.46 \\
\hline Solyc06g035920.2.1 & 30 & 1 & 1 & 1 & 1 & 5.9 & 30.5 \\
\hline Solyc01g090190.2.1 & 30 & 1 & 1 & 1 & 1 & 5.6 & 30.28 \\
\hline Solyc01g073970.2.1 & 30 & 1 & 1 & 1 & 1 & 5.1 & 30.14 \\
\hline Solyc08g068690.1.1 & 30 & 1 & 1 & 1 & 1 & 5 & 30.31 \\
\hline Solyc03g097110.2.1 & 30 & 1 & 1 & 1 & 1 & 4 & 30.4 \\
\hline Solyc06g066060.2.1 & 30 & 1 & 1 & 1 & 1 & 2.9 & 30.43 \\
\hline Solyc12g007030.1.1 & 30 & 1 & 1 & 1 & 1 & 2.6 & 29.53 \\
\hline Solyc02g071560.2.1 & 30 & 1 & 1 & 1 & 1 & 1.7 & 30.02 \\
\hline Solyc12g039120.1.1 & 29 & 2 & 1 & 2 & 1 & 11.9 & 29.38 \\
\hline Solyc11g066950.1.1 & 29 & 1 & 1 & 1 & 1 & 11.4 & 29.09 \\
\hline Solyc02g077880.2.1 & 29 & 1 & 1 & 1 & 1 & 10.6 & 29.32 \\
\hline Solyc01g108660.2.1 & 29 & 2 & 2 & 2 & 2 & 8.9 & 31.66 \\
\hline Solyc04g007750.2.1 & 27 & 1 & 1 & 1 & 1 & 6.1 & 27.28 \\
\hline Solyc08g007220.2.1 & 27 & 1 & 1 & 1 & 1 & 5.5 & 27.24 \\
\hline Solyc07g009140.2.1 & 27 & 1 & 1 & 1 & 1 & 3.4 & 27.31 \\
\hline Solyc05g052690.2.1 & 27 & 1 & 1 & 1 & 1 & 3.2 & 27.35 \\
\hline Solyc05g053960.2.1 & 26 & 2 & 2 & 1 & 1 & 5.8 & 24.54 \\
\hline Solyc01g094540.2.1 & 26 & 1 & 1 & 1 & 1 & 4.6 & 26.41 \\
\hline Solyc03g025340.1.1 & 23 & 1 & 1 & 1 & 1 & 10 & 23.07 \\
\hline Solyc08g078010.2.1 & 19 & 2 & 1 & 1 & 1 & 8.9 & 19.44 \\
\hline
\end{tabular}

zInformation used for the identification of proteins in iTRAQ analysis of tomato root proteomes.

yProtein accession number in the ITAG Protein database (Release 2.3 on 26 Apr. 2011; Sol Genomics Network, Boyce Thompson Institute, Ithaca, NY).

${ }^{\mathrm{x}}$ Sum of the individual ion scores.

wTotal number of peptide-spectral matches to a particular protein below the e-value cutoff.

vTotal number of unique peptide spectral matches to a particular protein below the e-value cutoff.

uTotal number of peptide spectral matches to a particular protein with a protein score above the identity threshold.

'Total number of unique peptide-spectral matches to a particular protein with a protein score above the identity threshold.

sercentage of the total protein sequence represented by the identified peptides.

${ }^{\mathrm{r}}$ Highest highest ion score for each identified proteins. 
Supplemental Table 3. Protein identification information of cherry tomato accession LA4133 using the isobaric tags for relative and absolute quantitation (iTRAQ) analysis. ${ }^{\mathrm{z}}$

\begin{tabular}{|c|c|c|c|c|c|c|c|}
\hline Accession $^{\mathrm{y}}$ & $\begin{array}{l}\text { Protein } \\
\text { score }^{\mathrm{x}}\end{array}$ & $\begin{array}{c}\text { Total } \\
\text { matches (no.) }\end{array}$ & $\begin{array}{c}\text { Unique } \\
\text { matches (no.) }\end{array}$ & $\begin{array}{c}\text { Total } \\
\text { sequences (no.) }\end{array}$ & $\begin{array}{c}\text { Unique } \\
\text { sequences (no.) }^{\mathrm{t}}\end{array}$ & $\begin{array}{c}\text { Protein } \\
\text { coverage }(\%)^{\mathrm{s}}\end{array}$ & $\begin{array}{c}\text { Highest } \\
\text { peptide score }^{\mathrm{r}} \\
\end{array}$ \\
\hline $\begin{array}{l}\text { Solyc07g052510.2.1 } \\
\text {. }\end{array}$ & 1686 & 44 & 41 & 13 & 12 & 44.2 & 109.83 \\
\hline Solyc05g008460.2.1 & 1428 & 59 & 52 & 19 & 18 & 52.1 & 90.58 \\
\hline Solyc04g007550.2.1 & 1398 & 61 & 53 & 19 & 18 & 53 & 90.58 \\
\hline Solyc09g090140.2.1 & 945 & 30 & 28 & 9 & 9 & 44.6 & 110.95 \\
\hline Solyc09g009020.2.1 & 927 & 34 & 27 & 15 & 13 & 60.1 & 95.09 \\
\hline Solyc07g062650.2.1 & 729 & 29 & 26 & 15 & 14 & 76 & 82.46 \\
\hline Solyc08g080630.2.1 & 672 & 26 & 25 & 3 & 3 & 28.6 & 80.89 \\
\hline Solyc10g081510.1.1 & 653 & 27 & 24 & 16 & 15 & 32 & 106.91 \\
\hline Solyc04g012120.2.1 & 605 & 23 & 21 & 6 & 6 & 35.7 & 87.1 \\
\hline Solyc03g006700.2.1 & 582 & 21 & 17 & 8 & 7 & 32.6 & 98.55 \\
\hline Solyc01g111760.2.1 & 571 & 24 & 21 & 12 & 12 & 40.9 & 65.95 \\
\hline Solyc 10g085550.1.1 & 561 & 21 & 18 & 11 & 10 & 42.8 & 95.09 \\
\hline Solyc06g009020.2.1 & 545 & 24 & 22 & 6 & 6 & 42.7 & 73.41 \\
\hline Solyc 10g055670.1.1 & 532 & 22 & 19 & 12 & 12 & 40.9 & 71.32 \\
\hline Solyc07g066600.2.1 & 529 & 26 & 21 & 10 & 9 & 40.9 & 74.52 \\
\hline Solyc01g106610.2.1 & 488 & 9 & 8 & 2 & 2 & 30.7 & 118.17 \\
\hline Solyc11g066390.1.1 & 442 & 11 & 9 & 4 & 3 & 38.7 & 98.68 \\
\hline Solyc00g071180.2.1 & 424 & 14 & 13 & 9 & 8 & 46.2 & 86.48 \\
\hline Solyc03g082920.2.1 & 407 & 16 & 16 & 10 & 10 & 24.3 & 80.37 \\
\hline Solyc03g078400.2.1 & 385 & 19 & 17 & 8 & 8 & 35.3 & 70.69 \\
\hline Solyc11g010200.1.1 & 377 & 14 & 12 & 4 & 4 & 20.8 & 79.45 \\
\hline Solyc01g059980.2.1 & 377 & 16 & 15 & 6 & 5 & 27.2 & 61.92 \\
\hline Solyc09g090980.2.1 & 377 & 22 & 19 & 9 & 8 & 72.5 & 74.4 \\
\hline Solyc11g067100.1.1 & 376 & 12 & 11 & 5 & 5 & 50.4 & 93.55 \\
\hline Solyc07g051850.2.1 & 375 & 9 & 9 & 7 & 7 & 23.6 & 93.61 \\
\hline Solyc08g082820.2.1 & 372 & 15 & 15 & 9 & 9 & 22.4 & 73.78 \\
\hline Solyc04g074510.2.1 & 349 & 12 & 11 & 4 & 4 & 22.8 & 75.94 \\
\hline Solyc05g014470.2.1 & 346 & 18 & 15 & 10 & 10 & 46.4 & 80.82 \\
\hline Solyc09g073000.2.1 & 337 & 11 & 11 & 6 & 6 & 21.8 & 87.59 \\
\hline Solyc01g105070.2.1 & 330 & 6 & 6 & 5 & 5 & 26.8 & 103.56 \\
\hline Solyc09g009260.2.1 & 325 & 17 & 13 & 8 & 7 & 33.5 & 74.66 \\
\hline Solyc12g057110.2.1 & 317 & 12 & 11 & 5 & 5 & 31.1 & 75.94 \\
\hline Solyc09g092380.2.1 & 317 & 16 & 15 & 9 & 9 & 30.1 & 66.65 \\
\hline Solyc03g115990.1.1 & 316 & 14 & 14 & 10 & 10 & 33 & 76.28 \\
\hline Solyc09g082060.2.1 & 314 & 9 & 9 & 5 & 5 & 31.4 & 72.21 \\
\hline Solyc02g067460.2.1 & 311 & 10 & 10 & 6 & 6 & 30.4 & 76.72 \\
\hline Solyc12g088670.1.1 & 310 & 12 & 11 & 7 & 6 & 21.2 & 65.51 \\
\hline Solyc06g073190.2.1 & 309 & 11 & 10 & 8 & 8 & 36 & 83.73 \\
\hline Solyc11g066060.1.1 & 309 & 21 & 18 & 12 & 11 & 25.9 & 56.15 \\
\hline Solyc01g100380.2.1 & 308 & 13 & 10 & 7 & 6 & 26.6 & 71.66 \\
\hline Solyc10g055800.1.1 & 303 & 11 & 11 & 5 & 5 & 29.5 & 107.25 \\
\hline Solyc06g005160.2.1 & 299 & 10 & 9 & 6 & 5 & 50 & 72.97 \\
\hline Solyc05g046020.2.1 & 297 & 14 & 12 & 8 & 6 & 30.9 & 106.58 \\
\hline Solyc04g077020.2.1 & 297 & 13 & 11 & 10 & 8 & 31.8 & 100.24 \\
\hline Solyc08g062920.2.1 & 294 & 12 & 10 & 10 & 8 & 22.6 & 117.68 \\
\hline Solyc06g052050.2.1 & 293 & 13 & 13 & 7 & 7 & 18.6 & 63.91 \\
\hline Solyc10g083570.1.1 & 292 & 15 & 11 & 7 & 6 & 26 & 74.66 \\
\hline Solyc09g008280.1.1 & 292 & 12 & 11 & 7 & 6 & 28.5 & 68.95 \\
\hline Solyc11g010470.1.1 & 281 & 11 & 9 & 5 & 4 & 30.5 & 88.2 \\
\hline Solyc03g111200.2.1 & 280 & 9 & 8 & 5 & 4 & 23.4 & 91.6 \\
\hline Solyc08g074680.2.1 & 278 & 9 & 8 & 7 & 6 & 6.2 & 83.97 \\
\hline Solyc12g055800.1.1 & 277 & 13 & 11 & 11 & 9 & 29.7 & 92.85 \\
\hline Solyc08g080670.1.1 & 272 & 14 & 12 & 4 & 4 & 22.8 & 58.25 \\
\hline Solyc04g049330.2.1 & 271 & 12 & 11 & 4 & 4 & 46.8 & 104.59 \\
\hline Solyc00g072400.2.1 & 270 & 12 & 8 & 7 & 6 & 39.5 & 87.16 \\
\hline Solyc05g053300.2.1 & 269 & 7 & 7 & 6 & 6 & 22.2 & 111.24 \\
\hline
\end{tabular}


Supplemental Table 3. Continued.

\begin{tabular}{|c|c|c|c|c|c|c|c|}
\hline Accession $^{y}$ & $\begin{array}{l}\text { Protein } \\
\text { score }^{\mathrm{x}}\end{array}$ & $\begin{array}{c}\text { Total } \\
\text { matches (no.) }\end{array}$ & $\begin{array}{c}\text { Unique } \\
\text { matches (no.) }\end{array}$ & $\begin{array}{c}\text { Total } \\
\text { sequences (no.) }\end{array}$ & $\begin{array}{c}\text { Unique } \\
\text { sequences (no.) }\end{array}$ & $\begin{array}{c}\text { Protein } \\
\text { coverage }(\%)^{\mathrm{s}}\end{array}$ & $\begin{array}{c}\text { Highest } \\
\text { peptide score }\end{array}$ \\
\hline Solyc05g053470.2.1 & 267 & 16 & 11 & 12 & 11 & 29.5 & 72.24 \\
\hline Solyc01g102310.2.1 & 266 & 10 & 10 & 10 & 10 & 23.3 & 70.77 \\
\hline Solyc02g070510.2.1 & 263 & 8 & 8 & 6 & 6 & 39.2 & 92.74 \\
\hline Solyc00g006800.2.1 & 263 & 8 & 7 & 7 & 6 & 23.6 & 116.97 \\
\hline Solyc03g098700.1.1 & 258 & 7 & 7 & 5 & 5 & 30.1 & 71.47 \\
\hline Solyc08g062660.2.1 & 257 & 7 & 6 & 5 & 4 & 35.3 & 76.89 \\
\hline Solyc12g010040.1.1 & 256 & 9 & 9 & 8 & 8 & 24.4 & 88.24 \\
\hline Solyc06g060290.2.1 & 252 & 13 & 9 & 9 & 6 & 31.1 & 50.25 \\
\hline Solyc02g084790.2.1 & 252 & 12 & 12 & 9 & 9 & 40.1 & 78.78 \\
\hline Solyc12g096700.1.1 & 251 & 10 & 9 & 5 & 5 & 40.2 & 73.63 \\
\hline Solyc10g078620.1.1 & 250 & 12 & 10 & 4 & 4 & 17.7 & 59.74 \\
\hline Solyc04g071890.2.1 & 250 & 10 & 7 & 8 & 7 & 36.2 & 105.44 \\
\hline Solyc07g053260.2.1 & 249 & 10 & 9 & 5 & 5 & 28.7 & 75.89 \\
\hline Solyc10g076220.1.1 & 249 & 7 & 7 & 6 & 6 & 33.5 & 83.87 \\
\hline Solyc06g073310.2.1 & 247 & 10 & 9 & 5 & 5 & 40.2 & 73.63 \\
\hline Solyc07g066610.2.1 & 246 & 10 & 9 & 5 & 5 & 16.8 & 73.14 \\
\hline Solyc07g045440.1.1 & 245 & 8 & 7 & 5 & 5 & 22.7 & 61.62 \\
\hline Solyc11g039980.1.1 & 245 & 7 & 6 & 5 & 5 & 44.2 & 85.9 \\
\hline Solyc11g072190.1.1 & 243 & 11 & 9 & 8 & 6 & 58.6 & 96.17 \\
\hline Solyc02g084800.2.1 & 240 & 10 & 10 & 8 & 8 & 42.1 & 77.99 \\
\hline Solyc02g063070.2.1 & 236 & 9 & 8 & 4 & 4 & 25 & 103.48 \\
\hline Solyc06g071920.2.1 & 235 & 7 & 7 & 5 & 5 & 22.8 & 79.76 \\
\hline Solyc02g084780.2.1 & 235 & 11 & 11 & 9 & 9 & 35.8 & 77.99 \\
\hline Solyc05g012480.2.1 & 233 & 6 & 6 & 3 & 3 & 8.4 & 76.1 \\
\hline Solyc09g009390.2.1 & 230 & 12 & 10 & 10 & 8 & 34.4 & 63.99 \\
\hline Solyc07g006650.2.1 & 229 & 5 & 5 & 3 & 3 & 13.6 & 76.42 \\
\hline Solyc01g101060.2.1 & 229 & 9 & 9 & 4 & 4 & 17.3 & 78.32 \\
\hline Solyc04g055170.2.1 & 227 & 7 & 7 & 6 & 6 & 22.8 & 83.48 \\
\hline Solyc02g082000.2.1 & 225 & 9 & 8 & 2 & 2 & 23.8 & 55.51 \\
\hline Solyc08g006860.2.1 & 225 & 10 & 8 & 6 & 5 & 21.9 & 81.56 \\
\hline Solyc01g067740.2.1 & 224 & 8 & 8 & 4 & 4 & 38.8 & 71.59 \\
\hline Solyc08g081530.2.1 & 224 & 7 & 7 & 6 & 6 & 19.5 & 73.86 \\
\hline Solyc02g038690.1.1 & 218 & 11 & 9 & 2 & 1 & 17.9 & 58.5 \\
\hline Solyc12g014180.1.1 & 218 & 7 & 7 & 6 & 6 & 28.1 & 82.7 \\
\hline Solyc12g005860.1.1 & 215 & 8 & 8 & 7 & 7 & 11.6 & 77.78 \\
\hline Solyc07g065840.2.1 & 215 & 11 & 9 & 9 & 7 & 19.2 & 71.92 \\
\hline Solyc12g099100.1.1 & 211 & 6 & 6 & 5 & 5 & 18.1 & 92.92 \\
\hline Solyc10g008010.2.1 & 211 & 7 & 7 & 5 & 5 & 42.6 & 67.87 \\
\hline Solyc01g090750.2.1 & 208 & 4 & 4 & 3 & 3 & 10.3 & 105.64 \\
\hline Solyc02g080210.2.1 & 205 & 12 & 9 & 6 & 5 & 15.4 & 46.63 \\
\hline Solyc01g109660.2.1 & 204 & 9 & 9 & 8 & 8 & 73.1 & 60.76 \\
\hline Solyc10g055810.1.1 & 203 & 7 & 5 & 5 & 4 & 32.9 & 90.81 \\
\hline Solyc04g049450.2.1 & 202 & 9 & 9 & 7 & 7 & 17.9 & 71.23 \\
\hline Solyc01g111170.2.1 & 200 & 10 & 8 & 4 & 3 & 39.8 & 63.44 \\
\hline Solyc00g009020.2.1 & 199 & 12 & 8 & 8 & 6 & 29.8 & 57.23 \\
\hline Solyc12g094620.1.1 & 197 & 9 & 6 & 6 & 5 & 21.5 & 46.45 \\
\hline Solyc11g011960.1.1 & 196 & 6 & 5 & 6 & 5 & 19.5 & 111.66 \\
\hline Solyc03g115110.2.1 & 195 & 7 & 6 & 6 & 5 & 32.1 & 63.96 \\
\hline Solyc07g043320.2.1 & 195 & 10 & 9 & 10 & 9 & 10.5 & 55.43 \\
\hline Solyc05g056020.2.1 & 194 & 4 & 4 & 2 & 2 & 34.2 & 81.78 \\
\hline Solyc11g005640.1.1 & 194 & 10 & 9 & 2 & 2 & 14.4 & 45.15 \\
\hline Solyc10g083650.1.1 & 193 & 4 & 4 & 3 & 3 & 25.9 & 93.06 \\
\hline Solyc01g111650.2.1 & 192 & 5 & 5 & 2 & 2 & 21.8 & 79.09 \\
\hline Solyc01g087120.2.1 & 192 & 8 & 6 & 4 & 3 & 20.5 & 63.53 \\
\hline Solyc07g052530.2.1 & 192 & 6 & 6 & 4 & 4 & 19.1 & 108.45 \\
\hline Solyc10g007290.2.1 & 192 & 10 & 7 & 8 & 6 & 15 & 73.42 \\
\hline Solyc01g100320.2.1 & 190 & 8 & 6 & 6 & 4 & 24.2 & 53.82 \\
\hline
\end{tabular}


Supplemental Table 3. Continued.

\begin{tabular}{|c|c|c|c|c|c|c|c|}
\hline Accession $^{y}$ & $\begin{array}{l}\text { Protein } \\
\text { score }^{\mathrm{x}}\end{array}$ & $\begin{array}{c}\text { Total } \\
\text { matches (no.) }\end{array}$ & $\begin{array}{c}\text { Unique } \\
\text { matches (no.) }\end{array}$ & $\begin{array}{c}\text { Total } \\
\text { sequences }(\text { no. })^{\mathrm{u}}\end{array}$ & $\begin{array}{c}\text { Unique } \\
\text { sequences (no.) } \\
\end{array}$ & $\begin{array}{c}\text { Protein } \\
\text { coverage }(\%)^{\mathrm{s}}\end{array}$ & $\begin{array}{c}\text { Highest } \\
\text { peptide score }^{\mathrm{r}}\end{array}$ \\
\hline Solyc06g068860.2.1 & 189 & 6 & 6 & 6 & 6 & 9.9 & 84.19 \\
\hline Solyc12g095960.1.1 & 188 & 7 & 5 & 4 & 3 & 23.3 & 106.45 \\
\hline Solyc01g106260.2.1 & 188 & 5 & 5 & 4 & 4 & 10.7 & 97.26 \\
\hline Solyc08g015690.2.1 & 188 & 9 & 9 & 8 & 8 & 34.1 & 62.94 \\
\hline Solyc12g015880.1.1 & 187 & 9 & 7 & 8 & 6 & 16.5 & 69.15 \\
\hline Solyc04g081570.2.1 & 186 & 8 & 5 & 7 & 4 & 13.2 & 59.95 \\
\hline Solyc07g044840.2.1 & 186 & 9 & 7 & 6 & 5 & 18.2 & 62.34 \\
\hline Solyc01g099760.2.1 & 186 & 10 & 9 & 6 & 6 & 24.8 & 61.17 \\
\hline Solyc04g011510.2.1 & 186 & 10 & 9 & 7 & 6 & 39.4 & 60.88 \\
\hline Solyc03g034180.2.1 & 184 & 7 & 6 & 3 & 3 & 17.8 & 103.48 \\
\hline Solyc07g042550.2.1 & 184 & 11 & 9 & 11 & 9 & 21.9 & 64.67 \\
\hline Solyc05g054580.2.1 & 183 & 7 & 7 & 4 & 4 & 19.9 & 68.65 \\
\hline Solyc08g080680.2.1 & 182 & 5 & 5 & 2 & 2 & 25.5 & 66.18 \\
\hline Solyc04g077970.2.1 & 181 & 4 & 3 & 2 & 1 & 15.8 & 93.08 \\
\hline Solyc11g073250.1.1 & 181 & 3 & 3 & 1 & 1 & 15.5 & 91.38 \\
\hline Solyc04g073990.2.1 & 181 & 10 & 9 & 8 & 8 & 31.5 & 49.56 \\
\hline Solyc07g043420.2.1 & 180 & 7 & 6 & 5 & 5 & 24 & 65.75 \\
\hline Solyc10g083970.1.1 & 179 & 7 & 7 & 4 & 4 & 17.2 & 68.95 \\
\hline Solyc12g042650.1.1 & 179 & 6 & 5 & 4 & 4 & 44.7 & 93.58 \\
\hline Solyc04g076060.2.1 & 179 & 10 & 8 & 5 & 4 & 30.2 & 88.2 \\
\hline Solyc06g082630.2.1 & 177 & 6 & 4 & 4 & 3 & 16.2 & 93.52 \\
\hline Solyc01g111120.2.1 & 175 & 7 & 6 & 4 & 3 & 16.9 & 58.39 \\
\hline Solyc01g080010.2.1 & 175 & 8 & 6 & 5 & 4 & 17.8 & 59.8 \\
\hline Solyc10g085020.1.1 & 175 & 11 & 8 & 8 & 6 & 24.2 & 62.86 \\
\hline Solyc10g080940.1.1 & 175 & 11 & 8 & 8 & 6 & 24.3 & 59.61 \\
\hline Solyc04g080850.2.1 & 174 & 9 & 6 & 4 & 2 & 35.8 & 56.28 \\
\hline Solyc12g008630.1.1 & 174 & 3 & 3 & 3 & 3 & 12.9 & 88.43 \\
\hline Solyc04g081490.2.1 & 174 & 11 & 7 & 8 & 5 & 23.7 & 62.86 \\
\hline Solyc01g103450.2.1 & 173 & 5 & 5 & 4 & 4 & 11.7 & 75.46 \\
\hline Solyc07g065120.2.1 & 173 & 6 & 5 & 5 & 5 & 11.8 & 57.9 \\
\hline Solyc01g102380.2.1 & 172 & 7 & 6 & 2 & 2 & 12.5 & 54.48 \\
\hline Solyc10g086100.1.1 & 171 & 6 & 5 & 2 & 2 & 33 & 71.66 \\
\hline Solyc06g035970.2.1 & 170 & 11 & 8 & 8 & 6 & 24.6 & 59.61 \\
\hline Solyc10g078550.1.1 & 169 & 9 & 9 & 6 & 6 & 25.8 & 56.17 \\
\hline Solyc03g114500.2.1 & 167 & 5 & 4 & 4 & 4 & 14.3 & 83.47 \\
\hline Solyc01g107910.2.1 & 166 & 4 & 4 & 4 & 4 & 31.5 & 98.54 \\
\hline Solyc11g069430.1.1 & 165 & 5 & 5 & 3 & 3 & 16.4 & 65.88 \\
\hline Solyc10g006650.2.1 & 164 & 3 & 3 & 2 & 2 & 17.2 & 93.07 \\
\hline Solyc01g009020.2.1 & 163 & 3 & 3 & 1 & 1 & 17.7 & 80.36 \\
\hline Solyc06g005940.2.1 & 162 & 9 & 9 & 6 & 6 & 17.6 & 43.8 \\
\hline Solyc08g079930.1.1 & 161 & 5 & 5 & 4 & 4 & 9.7 & 73.86 \\
\hline Solyc09g007520.2.1 & 161 & 4 & 4 & 4 & 4 & 24.4 & 83.12 \\
\hline Solyc09g090990.2.1 & 161 & 12 & 6 & 6 & 5 & 47.5 & 69.47 \\
\hline Solyc10g083720.1.1 & 159 & 2 & 2 & 2 & 2 & 7.6 & 127.56 \\
\hline Solyc04g082200.2.1 & 159 & 8 & 5 & 6 & 4 & 29.6 & 85.15 \\
\hline Solyc07g017780.2.1 & 159 & 8 & 6 & 8 & 6 & 13.8 & 66.51 \\
\hline Solyc04g014510.2.1 & 159 & 11 & 9 & 6 & 6 & 36.8 & 43.76 \\
\hline Solyc07g065110.1.1 & 157 & 7 & 7 & 2 & 2 & 27.9 & 65.23 \\
\hline Solyc01g008950.2.1 & 157 & 5 & 5 & 3 & 3 & 33.6 & 72.99 \\
\hline Solyc $10 \mathrm{~g} 055820.1 .1$ & 155 & 5 & 5 & 4 & 4 & 25.8 & 71.39 \\
\hline Solyc05g008600.2.1 & 155 & 9 & 6 & 5 & 4 & 23.5 & 51.34 \\
\hline Solyc05g052280.2.1 & 155 & 6 & 6 & 5 & 5 & 28.6 & 61.13 \\
\hline Solyc11g051160.1.1 & 153 & 4 & 3 & 4 & 3 & 12.7 & 67.18 \\
\hline Solyc04g074230.2.1 & 151 & 9 & 7 & 3 & 3 & 18.4 & 73.08 \\
\hline Solyc03g058920.2.1 & 151 & 7 & 6 & 5 & 5 & 17.5 & 55.86 \\
\hline Solyc05g055230.1.1 & 150 & 8 & 6 & 2 & 2 & 26.4 & 54.09 \\
\hline Solyc06g075180.1.1 & 149 & 7 & 6 & 4 & 4 & 35.5 & 67.1 \\
\hline
\end{tabular}


Supplemental Table 3. Continued.

\begin{tabular}{|c|c|c|c|c|c|c|c|}
\hline Accession $^{y}$ & $\begin{array}{c}\text { Protein } \\
\text { score }^{\mathrm{x}}\end{array}$ & $\begin{array}{c}\text { Total } \\
\text { matches (no.) }{ }^{\mathrm{w}}\end{array}$ & $\begin{array}{c}\text { Unique } \\
\text { matches (no.) }{ }^{\mathrm{v}}\end{array}$ & $\begin{array}{c}\text { Total } \\
\text { sequences }(\text { no. })^{\mathrm{u}}\end{array}$ & $\begin{array}{c}\text { Unique } \\
\text { sequences (no.) } \\
\end{array}$ & $\begin{array}{c}\text { Protein } \\
\text { coverage }(\%)^{\mathrm{s}}\end{array}$ & $\begin{array}{c}\text { Highest } \\
\text { peptide score } \\
\end{array}$ \\
\hline Solyc06g005150.2.1 & 147 & 6 & 5 & 4 & 3 & 34 & 52.51 \\
\hline Solyc09g090430.2.1 & 146 & 2 & 2 & 2 & 2 & 26.3 & 99.1 \\
\hline Solyc01g056940.2.1 & 146 & 7 & 7 & 2 & 2 & 16 & 45.15 \\
\hline Solyc10g078690.1.1 & 146 & 3 & 3 & 2 & 2 & 22.6 & 99.16 \\
\hline Solyc06g074980.2.1 & 146 & 4 & 3 & 4 & 3 & 7 & 90.95 \\
\hline Solyc03g111010.2.1 & 146 & 7 & 6 & 5 & 5 & 21.4 & 47.02 \\
\hline Solyc10g076240.1.1 & 145 & 6 & 6 & 5 & 5 & 26.2 & 55.85 \\
\hline Solyc02g068450.2.1 & 144 & 3 & 3 & 3 & 3 & 43.9 & 93.45 \\
\hline Solyc01g089970.2.1 & 144 & 4 & 4 & 4 & 4 & 26.4 & 72.97 \\
\hline Solyc02g077420.2.1 & 144 & 6 & 6 & 6 & 6 & 23.9 & 65.76 \\
\hline Solyc11g069400.1.1 & 143 & 3 & 3 & 2 & 2 & 6.7 & 64.62 \\
\hline Solyc11g062130.1.1 & 143 & 5 & 4 & 3 & 3 & 11.1 & 78.2 \\
\hline Solyc12g014210.1.1 & 142 & 2 & 2 & 2 & 2 & 11.3 & 99.65 \\
\hline Solyc04g071900.2.1 & 142 & 5 & 4 & 4 & 4 & 16.2 & 65.42 \\
\hline Solyc04g054980.2.1 & 141 & 4 & 3 & 3 & 2 & 25 & 72.63 \\
\hline Solyc10g050160.1.1 & 141 & 5 & 5 & 3 & 3 & 19.2 & 98.54 \\
\hline Solyc03g096540.2.1 & 140 & 3 & 3 & 3 & 3 & 27.7 & 81.69 \\
\hline Solyc08g080650.1.1 & 140 & 9 & 9 & 5 & 5 & 33.7 & 52.7 \\
\hline Solyc10g086190.1.1 & 139 & 5 & 4 & 3 & 3 & 14.5 & 63.98 \\
\hline Solyc01g103800.2.1 & 139 & 5 & 5 & 4 & 4 & 44.1 & 64.49 \\
\hline Solyc06g059740.2.1 & 137 & 4 & 4 & 4 & 4 & 19.3 & 77.57 \\
\hline Solyc02g081700.1.1 & 137 & 5 & 5 & 4 & 4 & 24.6 & 95.48 \\
\hline Solyc07g047740.2.1 & 136 & 7 & 7 & 3 & 3 & 13.9 & 67.83 \\
\hline Solyc06g069090.2.1 & 135 & 5 & 3 & 4 & 2 & 35.1 & 97.23 \\
\hline Solyc03g112070.2.1 & 135 & 4 & 4 & 3 & 3 & 9.2 & 66.53 \\
\hline Solyc10g005960.1.1 & 135 & 3 & 3 & 3 & 3 & 13.3 & 81.1 \\
\hline Solyc12g010860.1.1 & 134 & 5 & 4 & 4 & 4 & 24.9 & 69.56 \\
\hline Solyc07g055080.2.1 & 134 & 5 & 5 & 4 & 4 & 29.8 & 65.01 \\
\hline Solyc02g086880.2.1 & 133 & 2 & 2 & 2 & 2 & 9.4 & 126.1 \\
\hline Solyc11g069000.1.1 & 133 & 3 & 3 & 3 & 3 & 11.8 & 72.07 \\
\hline Solyc01g099770.2.1 & 133 & 6 & 6 & 4 & 4 & 29.2 & 45.07 \\
\hline Solyc07g041310.2.1 & 132 & 4 & 4 & 4 & 4 & 18.8 & 82.71 \\
\hline Solyc10g008140.2.1 & 131 & 3 & 2 & 3 & 2 & 20.8 & 85.49 \\
\hline Solyc06g083620.2.1 & 131 & 4 & 3 & 4 & 3 & 16.2 & 70.73 \\
\hline Solyc06g071100.2.1 & 131 & 6 & 4 & 6 & 4 & 10 & 74.52 \\
\hline Solyc08g079170.2.1 & 131 & 5 & 5 & 5 & 5 & 11.4 & 63.98 \\
\hline Solyc03g096460.2.1 & 130 & 6 & 5 & 2 & 2 & 14.7 & 57.22 \\
\hline Solyc01g106620.2.1 & 129 & 5 & 3 & 2 & 2 & 21.2 & 79.91 \\
\hline Solyc09g007940.2.1 & 129 & 5 & 4 & 3 & 3 & 18.5 & 63.98 \\
\hline Solyc07g020860.2.1 & 128 & 8 & 6 & 4 & 3 & 36.4 & 44.12 \\
\hline Solyc06g005060.2.1 & 128 & 7 & 6 & 4 & 4 & 12.5 & 50.38 \\
\hline Solyc04g011500.2.1 & 128 & 8 & 6 & 5 & 5 & 22.5 & 50.82 \\
\hline Solyc08g081190.2.1 & 127 & 5 & 5 & 2 & 2 & 11.9 & 52.07 \\
\hline Solyc12g009140.1.1 & 127 & 3 & 3 & 2 & 2 & 13.4 & 62.67 \\
\hline Solyc08g061850.2.1 & 127 & 4 & 3 & 4 & 3 & 16.4 & 82.71 \\
\hline Solyc01g106210.2.1 & 126 & 7 & 7 & 4 & 4 & 8.8 & 43.09 \\
\hline Solyc07g008720.2.1 & 125 & 5 & 5 & 4 & 4 & 41.4 & 68.68 \\
\hline Solyc11g069790.1.1 & 124 & 6 & 4 & 6 & 4 & 14.6 & 74.97 \\
\hline Solyc08g080660.1.1 & 124 & 9 & 7 & 4 & 4 & 22.8 & 46.47 \\
\hline Solyc01g109940.2.1 & 124 & 6 & 5 & 4 & 4 & 16.1 & 55.04 \\
\hline Solyc04g079180.2.1 & 123 & 5 & 4 & 3 & 3 & 19.6 & 65.4 \\
\hline Solyc02g023970.2.1 & 123 & 3 & 3 & 3 & 3 & 14 & 64.33 \\
\hline Solyc03g113580.1.1 & 123 & 5 & 4 & 5 & 4 & 30 & 59.06 \\
\hline Solyc06g072580.2.1 & 123 & 5 & 5 & 4 & 4 & 14.7 & 47.96 \\
\hline Solyc10g080500.1.1 & 123 & 8 & 6 & 5 & 5 & 22.5 & 50.82 \\
\hline Solyc10g081030.1.1 & 122 & 7 & 6 & 3 & 3 & 23.1 & 62.71 \\
\hline Solyc11g011380.1.1 & 122 & 9 & 9 & 6 & 6 & 37.3 & 64.6 \\
\hline
\end{tabular}


Supplemental Table 3. Continued.

\begin{tabular}{|c|c|c|c|c|c|c|c|}
\hline Accession $^{y}$ & $\begin{array}{l}\text { Protein } \\
\text { score }^{\mathrm{x}}\end{array}$ & $\begin{array}{c}\text { Total } \\
\text { matches (no.) }\end{array}$ & $\begin{array}{c}\text { Unique } \\
\text { matches (no.) }\end{array}$ & $\begin{array}{c}\text { Total } \\
\text { sequences (no.) })^{\mathrm{u}}\end{array}$ & $\begin{array}{c}\text { Unique } \\
\text { sequences (no.) }\end{array}$ & $\begin{array}{c}\text { Protein } \\
\text { coverage }(\%)^{\mathrm{s}}\end{array}$ & $\begin{array}{c}\text { Highest } \\
\text { peptide score }\end{array}$ \\
\hline Solyc09g091840.2.1 & 121 & 5 & 4 & 4 & 4 & 13.7 & 48.18 \\
\hline Solyc05g054480.2.1 & 121 & 8 & 6 & 5 & 5 & 22.5 & 50.82 \\
\hline Solyc01g011000.2.1 & 121 & 7 & 7 & 6 & 6 & 50.9 & 76.93 \\
\hline Solyc07g052350.2.1 & 120 & 6 & 6 & 5 & 5 & 8.9 & 54.95 \\
\hline Solyc01g111300.2.1 & 119 & 4 & 3 & 3 & 2 & 28.3 & 55.69 \\
\hline Solyc03g113400.2.1 & 119 & 5 & 3 & 5 & 3 & 8.5 & 74.52 \\
\hline Solyc02g062510.2.1 & 118 & 5 & 5 & 4 & 4 & 16 & 80.24 \\
\hline Solyc09g091180.2.1 & 118 & 12 & 8 & 9 & 8 & 21.9 & 46.7 \\
\hline Solyc06g067960.2.1 & 116 & 2 & 2 & 1 & 1 & 10 & 84.37 \\
\hline Solyc01g079980.2.1 & 116 & 4 & 3 & 2 & 2 & 9.8 & 60.68 \\
\hline Solyc02g093230.2.1 & 116 & 2 & 2 & 2 & 2 & 14.9 & 98.54 \\
\hline Solyc01g008000.2.1 & 115 & 7 & 4 & 5 & 4 & 30.6 & 56.64 \\
\hline Solyc05g053810.2.1 & 114 & 4 & 4 & 3 & 3 & 10.8 & 51.93 \\
\hline Solyc05g018570.2.1 & 114 & 5 & 4 & 3 & 3 & 11.5 & 53.61 \\
\hline Solyc01g091530.2.1 & 114 & 4 & 4 & 4 & 4 & 15.5 & 69.03 \\
\hline Solyc04g011390.1.1 & 113 & 6 & 5 & 4 & 3 & 40.8 & 74.17 \\
\hline Solyc03g096550.2.1 & 113 & 5 & 5 & 3 & 3 & 23.5 & 56.35 \\
\hline Solyc05g054760.2.1 & 113 & 5 & 5 & 5 & 5 & 36.7 & 53.62 \\
\hline Solyc12g043110.1.1 & 113 & 5 & 5 & 5 & 5 & 8.9 & 62.52 \\
\hline Solyc03g097270.2.1 & 112 & 4 & 4 & 4 & 4 & 25.5 & 56.09 \\
\hline Solyc01g044360.2.1 & 111 & 1 & 1 & 1 & 1 & 2.1 & 111.33 \\
\hline Solyc08g075090.2.1 & 111 & 4 & 4 & 2 & 2 & 4.3 & 55.55 \\
\hline Solyc08g080640.1.1 & 111 & 6 & 6 & 4 & 4 & 25.9 & 52.7 \\
\hline Solyc03g006580.2.1 & 110 & 1 & 1 & 1 & 1 & 9.9 & 109.87 \\
\hline Solyc09g005500.2.1 & 110 & 3 & 2 & 2 & 1 & 27.8 & 64.84 \\
\hline Solyc06g082120.2.1 & 110 & 3 & 3 & 2 & 2 & 16.6 & 57.74 \\
\hline Solyc01g073740.2.1 & 110 & 4 & 4 & 3 & 3 & 9.3 & 67.51 \\
\hline Solyc07g045240.2.1 & 109 & 2 & 2 & 2 & 2 & 9.6 & 91.08 \\
\hline Solyc04g080960.2.1 & 109 & 3 & 3 & 3 & 3 & 16 & 64.08 \\
\hline Solyc11g007690.1.1 & 108 & 1 & 1 & 1 & 1 & 5.1 & 107.65 \\
\hline Solyc05g050120.2.1 & 108 & 4 & 2 & 4 & 2 & 12.8 & 66.73 \\
\hline Solyc01g097460.2.1 & 108 & 2 & 2 & 2 & 2 & 14.3 & 72.75 \\
\hline Solyc08g067020.2.1 & 108 & 7 & 5 & 3 & 2 & 33.3 & 44.9 \\
\hline Solyc08g062800.2.1 & 108 & 5 & 4 & 4 & 3 & 15.3 & 58.86 \\
\hline Solyc03g025800.2.1 & 107 & 2 & 2 & 1 & 1 & 14.8 & 82.36 \\
\hline Solyc10g084400.1.1 & 107 & 4 & 4 & 2 & 2 & 13.6 & 32.85 \\
\hline Solyc10g084400.1.1 & 107 & 4 & 4 & 2 & 2 & 13.6 & 76.11 \\
\hline Solyc01g005560.2.1 & 107 & 4 & 3 & 4 & 3 & 13 & 62.88 \\
\hline Solyc02g071560.2.1 & 106 & 4 & 3 & 3 & 2 & 6 & 52.21 \\
\hline Solyc01g111450.2.1 & 106 & 5 & 3 & 4 & 3 & 21.7 & 44.78 \\
\hline Solyc08g079260.2.1 & 106 & 7 & 6 & 5 & 5 & 14.2 & 37.5 \\
\hline Solyc10g005510.2.1 & 105 & 4 & 4 & 4 & 4 & 16.9 & 50.92 \\
\hline Solyc02g088700.2.1 & 104 & 2 & 2 & 2 & 2 & 5.8 & 82.19 \\
\hline Solyc08g006850.2.1 & 104 & 4 & 4 & 3 & 3 & 10.6 & 52.7 \\
\hline Solyc01g079540.2.1 & 104 & 3 & 3 & 3 & 3 & 17.6 & 77.29 \\
\hline Solyc04g080540.2.1 & 103 & 1 & 1 & 1 & 1 & 14.2 & 102.89 \\
\hline Solyc02g078650.2.1 & 103 & 2 & 2 & 2 & 2 & 5.9 & 67.04 \\
\hline Solyc03g119360.2.1 & 103 & 5 & 3 & 4 & 2 & 35.1 & 73.65 \\
\hline Solyc07g053540.1.1 & 103 & 7 & 6 & 2 & 2 & 10.5 & 43.99 \\
\hline Solyc03g080180.2.1 & 103 & 3 & 3 & 3 & 3 & 13.7 & 63.41 \\
\hline Solyc06g075010.2.1 & 103 & 3 & 3 & 3 & 3 & 6.5 & 85.01 \\
\hline Solyc05g006520.2.1 & 103 & 4 & 4 & 4 & 4 & 14.3 & 47.58 \\
\hline Solyc06g074430.2.1 & 102 & 5 & 4 & 3 & 2 & 34.2 & 52.94 \\
\hline Solyc06g064940.2.1 & 102 & 2 & 2 & 2 & 2 & 5.9 & 66.55 \\
\hline Solyc12g056960.1.1 & 102 & 2 & 2 & 2 & 2 & 6.8 & 80.01 \\
\hline Solyc10g007600.2.1 & 101 & 2 & 2 & 1 & 1 & 4.6 & 68.53 \\
\hline Solyc04g080570.2.1 & 101 & 2 & 1 & 2 & 1 & 16.5 & 100.75 \\
\hline
\end{tabular}


Supplemental Table 3. Continued.

\begin{tabular}{|c|c|c|c|c|c|c|c|}
\hline Accession $^{y}$ & $\begin{array}{l}\text { Protein } \\
\text { score }^{\mathrm{x}}\end{array}$ & $\begin{array}{c}\text { Total } \\
\text { matches (no.) }\end{array}$ & $\begin{array}{c}\text { Unique } \\
\text { matches (no.) }\end{array}$ & $\begin{array}{c}\text { Total } \\
\text { sequences }(\text { no. })^{\mathrm{u}}\end{array}$ & $\begin{array}{c}\text { Unique } \\
\text { sequences (no.) } \\
\end{array}$ & $\begin{array}{c}\text { Protein } \\
\text { coverage }(\%)^{\mathrm{s}}\end{array}$ & $\begin{array}{c}\text { Highest } \\
\text { peptide score }\end{array}$ \\
\hline Solyc06g050770.2.1 & 101 & 4 & 4 & 3 & 3 & 15.2 & 56.28 \\
\hline Solyc06g005260.2.1 & 101 & 4 & 4 & 4 & 4 & 46.3 & 62.07 \\
\hline Solyc12g009400.1.1 & 100 & 1 & 1 & 1 & 1 & 4.5 & 100.41 \\
\hline Solyc11g070050.1.1 & 100 & 2 & 2 & 2 & 2 & 22.3 & 64.24 \\
\hline Solyc08g075830.2.1 & 99 & 6 & 5 & 3 & 2 & 11.2 & 57.82 \\
\hline Solyc12g096300.1.1 & 99 & 2 & 2 & 2 & 2 & 12.9 & 65 \\
\hline Solyc12g088760.1.1 & 98 & 3 & 3 & 3 & 3 & 7.1 & 52.87 \\
\hline Solyc12g043120.1.1 & 98 & 5 & 5 & 5 & 5 & 9.5 & 45.76 \\
\hline Solyc04g008740.2.1 & 98 & 5 & 5 & 5 & 5 & 15.3 & 49.14 \\
\hline Solyc10g081310.1.1 & 97 & 3 & 3 & 3 & 3 & 37.7 & 67.7 \\
\hline Solyc06g072120.2.1 & 97 & 4 & 3 & 4 & 3 & 20.9 & 58.47 \\
\hline Solyc01g010760.2.1 & 97 & 4 & 4 & 4 & 4 & 19.9 & 64.14 \\
\hline Solyc06g011280.2.1 & 96 & 2 & 2 & 1 & 1 & 4.6 & 60.33 \\
\hline Solyc02g065400.2.1 & 96 & 1 & 1 & 1 & 1 & 6.4 & 95.72 \\
\hline Solyc03g032000.2.1 & 96 & 3 & 2 & 3 & 2 & 19.8 & 55.06 \\
\hline Solyc01g094200.2.1 & 96 & 2 & 2 & 2 & 2 & 6.2 & 66.97 \\
\hline Solyc12g056120.1.1 & 95 & 4 & 3 & 3 & 2 & 12.3 & 73.24 \\
\hline Solyc02g079500.2.1 & 95 & 3 & 3 & 3 & 3 & 10.7 & 58.44 \\
\hline Solyc04g063290.2.1 & 95 & 6 & 4 & 5 & 4 & 27.9 & 43.46 \\
\hline Solyc03g121640.2.1 & 94 & 1 & 1 & 1 & 1 & 4 & 94.4 \\
\hline Solyc06g073370.2.1 & 94 & 1 & 1 & 1 & 1 & 13.2 & 94.01 \\
\hline Solyc01g099780.2.1 & 94 & 4 & 4 & 3 & 3 & 21.4 & 45.07 \\
\hline Solyc07g005560.2.1 & 94 & 4 & 3 & 3 & 3 & 33.1 & 71.24 \\
\hline Solyc08g079020.2.1 & 93 & 1 & 1 & 1 & 1 & 12.6 & 92.96 \\
\hline Solyc01g104170.2.1 & 93 & 3 & 3 & 2 & 2 & 10.6 & 55.64 \\
\hline Solyc03g119040.2.1 & 93 & 3 & 3 & 3 & 3 & 14.7 & 54.34 \\
\hline Solyc09g018590.1.1 & 92 & 1 & 1 & 1 & 1 & 8.8 & 92.24 \\
\hline Solyc03g025270.2.1 & 92 & 1 & 1 & 1 & 1 & 6.4 & 92.21 \\
\hline Solyc11g020870.1.1 & 92 & 1 & 1 & 1 & 1 & 5.9 & 91.61 \\
\hline Solyc10g079890.1.1 & 91 & 1 & 1 & 1 & 1 & 6.2 & 91.45 \\
\hline Solyc11g011330.1.1 & 91 & 3 & 2 & 3 & 2 & 15.2 & 69.4 \\
\hline Solyc10g078740.1.1 & 91 & 5 & 3 & 5 & 3 & 20.7 & 42.38 \\
\hline Solyc06g083190.2.1 & 90 & 5 & 2 & 5 & 2 & 13.8 & 61.74 \\
\hline Solyc05g046000.2.1 & 90 & 5 & 5 & 2 & 2 & 7.8 & 61.94 \\
\hline Solyc06g062380.2.1 & 90 & 2 & 2 & 2 & 2 & 15 & 67.2 \\
\hline Solyc09g057670.2.1 & 90 & 7 & 4 & 5 & 3 & 49 & 44.23 \\
\hline Solyc01g103480.2.1 & 90 & 3 & 3 & 3 & 3 & 8.5 & 66.35 \\
\hline Solyc03g025850.2.1 & 90 & 4 & 4 & 4 & 4 & 26.9 & 49.91 \\
\hline Solyc10g081720.1.1 & 89 & 2 & 2 & 1 & 1 & 3.8 & 74 \\
\hline Solyc09g018750.2.1 & 89 & 4 & 2 & 3 & 2 & 25.9 & 54.63 \\
\hline Solyc03g007660.2.1 & 89 & 2 & 2 & 2 & 2 & 19 & 28.34 \\
\hline Solyc11g012870.1.1 & 89 & 3 & 2 & 3 & 2 & 15.3 & 51.16 \\
\hline Solyc01g104370.2.1 & 88 & 2 & 2 & 1 & 1 & 14.3 & 58.98 \\
\hline Solyc05g052690.2.1 & 88 & 1 & 1 & 1 & 1 & 7 & 88.39 \\
\hline Solyc10g005100.2.1 & 88 & 4 & 2 & 2 & 1 & 10 & 47.68 \\
\hline Solyc10g078150.1.1 & 88 & 4 & 3 & 2 & 1 & 15.2 & 62.71 \\
\hline Solyc07g041490.1.1 & 88 & 1 & 1 & 1 & 1 & 7.1 & 88.02 \\
\hline Solyc02g070570.2.1 & 88 & 2 & 2 & 2 & 2 & 20.7 & 81.36 \\
\hline Solyc07g064800.2.1 & 88 & 3 & 2 & 3 & 2 & 12 & 75.34 \\
\hline Solyc02g084920.2.1 & 88 & 3 & 3 & 3 & 3 & 26.5 & 53.67 \\
\hline Solyc12g010060.1.1 & 87 & 3 & 3 & 3 & 3 & 22.5 & 59.49 \\
\hline Solyc02g082900.2.1 & 86 & 1 & 1 & 1 & 1 & 5.7 & 86.49 \\
\hline Solyc09g009640.2.1 & 86 & 1 & 1 & 1 & 1 & 18.2 & 86.35 \\
\hline Solyc11g068830.1.1 & 86 & 2 & 1 & 2 & 1 & 9.4 & 85.93 \\
\hline Solyc03g080160.2.1 & 86 & 5 & 5 & 5 & 5 & 35.3 & 44.97 \\
\hline Solyc07g042250.2.1 & 85 & 2 & 2 & 1 & 1 & 8.7 & 76.59 \\
\hline Solyc12g096520.1.1 & 85 & 1 & 1 & 1 & 1 & 7.5 & 84.67 \\
\hline
\end{tabular}


Supplemental Table 3. Continued.

\begin{tabular}{|c|c|c|c|c|c|c|c|}
\hline Accession $^{y}$ & $\begin{array}{l}\text { Protein } \\
\text { score }^{\mathrm{x}}\end{array}$ & $\begin{array}{c}\text { Total } \\
\text { matches (no.) }\end{array}$ & $\begin{array}{c}\text { Unique } \\
\text { matches (no.) }\end{array}$ & $\begin{array}{c}\text { Total } \\
\text { sequences (no.) })^{\mathrm{u}}\end{array}$ & $\begin{array}{c}\text { Unique } \\
\text { sequences (no.) }\end{array}$ & $\begin{array}{c}\text { Protein } \\
\text { coverage }(\%)^{\mathrm{s}}\end{array}$ & $\begin{array}{c}\text { Highest } \\
\text { peptide score }\end{array}$ \\
\hline$\overline{\text { Solyc02g080810.2.1 }}$ & 85 & 3 & 2 & 3 & 2 & 13.5 & 62.11 \\
\hline Solyc03g118340.2.1 & 85 & 2 & 2 & 2 & 2 & 4.5 & 63.78 \\
\hline Solyc09g091000.2.1 & 85 & 4 & 4 & 3 & 3 & 30.3 & 41.75 \\
\hline Solyc03g078290.2.1 & 84 & 1 & 1 & 1 & 1 & 13.2 & 84.41 \\
\hline Solyc01g099410.2.1 & 84 & 3 & 2 & 2 & 1 & 20.5 & 81.78 \\
\hline Solyc09g064370.2.1 & 84 & 2 & 1 & 2 & 1 & 10.5 & 84.03 \\
\hline Solyc05g055770.2.1 & 84 & 1 & 1 & 1 & 1 & 5.1 & 83.9 \\
\hline Solyc01g109620.2.1 & 84 & 2 & 2 & 2 & 2 & 15.3 & 60.17 \\
\hline Solyc01g102390.2.1 & 84 & 4 & 3 & 2 & 2 & 13.2 & 49.83 \\
\hline Solyc08g006040.2.1 & 84 & 2 & 2 & 2 & 2 & 12.9 & 65 \\
\hline Solyc01g103370.2.1 & 83 & 2 & 2 & 2 & 2 & 17.8 & 52.69 \\
\hline Solyc02g063130.2.1 & 83 & 3 & 3 & 2 & 2 & 6.3 & 58.27 \\
\hline Solyc06g068320.2.1 & 82 & 1 & 1 & 1 & 1 & 2.9 & 82.3 \\
\hline Solyc03g097900.2.1 & 82 & 3 & 3 & 2 & 2 & 11.1 & 49.9 \\
\hline Solyc10g076510.1.1 & 82 & 2 & 2 & 2 & 2 & 5.3 & 54.43 \\
\hline Solyc06g050980.2.1 & 82 & 4 & 3 & 3 & 2 & 20.7 & 51.01 \\
\hline Solyc02g077000.2.1 & 82 & 2 & 2 & 2 & 2 & 7.9 & 65.76 \\
\hline Solyc02g080630.2.1 & 82 & 3 & 3 & 3 & 3 & 12.9 & 52.27 \\
\hline Solyc01g006900.2.1 & 82 & 4 & 4 & 3 & 3 & 24.5 & 56.67 \\
\hline Solyc01g097270.2.1 & 81 & 2 & 2 & 1 & 1 & 8.5 & 58.97 \\
\hline Solyc10g074690.1.1 & 81 & 1 & 1 & 1 & 1 & 4.4 & 80.78 \\
\hline Solyc02g086460.2.1 & 81 & 2 & 2 & 2 & 2 & 0.8 & 58.75 \\
\hline Solyc04g011400.2.1 & 81 & 3 & 3 & 2 & 2 & 9 & 65.43 \\
\hline Solyc05g055280.1.1 & 81 & 2 & 2 & 2 & 2 & 28.6 & 61.33 \\
\hline Solyc03g033710.2.1 & 81 & 4 & 4 & 3 & 3 & 10.8 & 73.09 \\
\hline Solyc01g006290.2.1 & 80 & 2 & 2 & 1 & 1 & 5.5 & 67.26 \\
\hline Solyc02g077240.2.1 & 80 & 1 & 1 & 1 & 1 & 3.4 & 79.95 \\
\hline Solyc09g010420.2.1 & 80 & 1 & 1 & 1 & 1 & 4 & 79.62 \\
\hline Solyc10g006290.2.1 & 80 & 2 & 2 & 2 & 2 & 18.2 & 51.98 \\
\hline Solyc01g095150.2.1 & 80 & 6 & 4 & 5 & 3 & 39.7 & 45.49 \\
\hline Solyc04g074480.2.1 & 80 & 3 & 3 & 3 & 3 & 9.1 & 56.57 \\
\hline Solyc11g072450.1.1 & 80 & 6 & 3 & 5 & 3 & 31 & 39.92 \\
\hline Solyc12g095760.1.1 & 80 & 4 & 3 & 4 & 3 & 11 & 52.52 \\
\hline Solyc08g079090.2.1 & 79 & 3 & 3 & 2 & 2 & 5.6 & 58.11 \\
\hline Solyc04g081440.2.1 & 79 & 2 & 2 & 2 & 2 & 6.3 & 60.12 \\
\hline Solyc07g016150.2.1 & 79 & 3 & 3 & 3 & 3 & 30.7 & 53.76 \\
\hline Solyc05g050970.2.1 & 79 & 4 & 3 & 4 & 3 & 7.9 & 43.37 \\
\hline Solyc07g008130.2.1 & 78 & 1 & 1 & 1 & 1 & 11.2 & 78.34 \\
\hline Solyc05g012270.2.1 & 78 & 1 & 1 & 1 & 1 & 3.4 & 77.77 \\
\hline Solyc04g005340.2.1 & 78 & 4 & 4 & 3 & 3 & 12 & 48.02 \\
\hline Solyc01g107870.2.1 & 78 & 4 & 4 & 4 & 4 & 9.5 & 38.62 \\
\hline Solyc09g075940.2.1 & 77 & 1 & 1 & 1 & 1 & 2.7 & 76.91 \\
\hline Solyc08g014130.2.1 & 77 & 2 & 2 & 2 & 2 & 5.9 & 58.2 \\
\hline Solyc06g005360.2.1 & 76 & 2 & 1 & 2 & 1 & 23.4 & 76.43 \\
\hline Solyc02g068740.2.1 & 76 & 2 & 2 & 1 & 1 & 10.4 & 54.94 \\
\hline Solyc03g098710.1.1 & 76 & 2 & 2 & 2 & 2 & 15.2 & 53.73 \\
\hline Solyc06g050590.2.1 & 75 & 2 & 1 & 2 & 1 & 9.3 & 67.26 \\
\hline Solyc09g075450.2.1 & 75 & 2 & 2 & 2 & 2 & 8.3 & 50.39 \\
\hline Solyc09g072700.2.1 & 75 & 5 & 5 & 2 & 2 & 9.3 & 53.13 \\
\hline Solyc04g009410.2.1 & 74 & 1 & 1 & 1 & 1 & 8.8 & 74.26 \\
\hline Solyc07g064240.2.1 & 74 & 2 & 2 & 1 & 1 & 6.4 & 51.48 \\
\hline Solyc01g060470.2.1 & 74 & 1 & 1 & 1 & 1 & 4 & 73.97 \\
\hline Solyc01g087850.2.1 & 74 & 2 & 2 & 2 & 2 & 4.6 & 46.35 \\
\hline Solyc04g071610.2.1 & 74 & 3 & 3 & 2 & 2 & 34.5 & 49.29 \\
\hline Solyc06g060260.2.1 & 74 & 3 & 3 & 3 & 3 & 13.6 & 45.44 \\
\hline Solyc06g007610.2.1 & 73 & 2 & 2 & 1 & 1 & 13 & 56.13 \\
\hline Solyc09g064450.2.1 & 73 & 1 & 1 & 1 & 1 & 4.5 & 72.66 \\
\hline
\end{tabular}


Supplemental Table 3. Continued.

\begin{tabular}{|c|c|c|c|c|c|c|c|}
\hline Accession $^{y}$ & $\begin{array}{l}\text { Protein } \\
\text { score }^{\mathrm{x}}\end{array}$ & $\begin{array}{c}\text { Total } \\
\text { matches (no.) }\end{array}$ & $\begin{array}{c}\text { Unique } \\
\text { matches (no.) }^{\mathrm{v}}\end{array}$ & $\begin{array}{c}\text { Total } \\
\text { sequences }(\text { no. })^{\mathrm{u}}\end{array}$ & $\begin{array}{c}\text { Unique } \\
\text { sequences (no.) }^{\mathrm{t}}\end{array}$ & $\begin{array}{c}\text { Protein } \\
\text { coverage }(\%)^{\mathrm{s}}\end{array}$ & $\begin{array}{c}\text { Highest } \\
\text { peptide score }\end{array}$ \\
\hline$\overline{\text { Solyc12g042900.1.1 }}$ & 73 & 2 & 2 & 1 & 1 & 8.7 & 48.93 \\
\hline Solyc08g078070.2.1 & 72 & 1 & 1 & 1 & 1 & 9.4 & 72.49 \\
\hline Solyc01g097520.2.1 & 72 & 1 & 1 & 1 & 1 & 5.7 & 72.46 \\
\hline Solyc06g066830.2.1 & 72 & 1 & 1 & 1 & 1 & 6.1 & 72.43 \\
\hline Solyc02g067840.2.1 & 72 & 1 & 1 & 1 & 1 & 5.3 & 72.17 \\
\hline Solyc02g088460.2.1 & 72 & 1 & 1 & 1 & 1 & 5.4 & 71.99 \\
\hline Solyc03g083390.2.1 & 72 & 2 & 1 & 2 & 1 & 11.3 & 28.26 \\
\hline Solyc03g083390.2.1 & 72 & 2 & 1 & 2 & 1 & 11.3 & 60.17 \\
\hline Solyc05g056310.2.1 & 72 & 1 & 1 & 1 & 1 & 3.2 & 71.81 \\
\hline Solyc05g055760.2.1 & 72 & 2 & 2 & 2 & 2 & 15.7 & 46.35 \\
\hline Solyc01g104590.2.1 & 72 & 2 & 2 & 2 & 2 & 7.5 & 50.95 \\
\hline Solyc03g120470.2.1 & 71 & 1 & 1 & 1 & 1 & 1.5 & 70.74 \\
\hline Solyc02g093900.2.1 & 71 & 2 & 2 & 2 & 2 & 11.2 & 64.66 \\
\hline Solyc05g009530.2.1 & 71 & 2 & 2 & 2 & 2 & 6.8 & 60.7 \\
\hline Solyc03g079930.2.1 & 71 & 3 & 3 & 2 & 2 & 16.3 & 52.15 \\
\hline Solyc10g049890.1.1 & 71 & 2 & 2 & 2 & 2 & 5.4 & 60.12 \\
\hline Solyc02g079750.2.1 & 71 & 4 & 4 & 3 & 3 & 18.4 & 36.12 \\
\hline Solyc06g083790.2.1 & 71 & 4 & 4 & 4 & 4 & 12.1 & 39.67 \\
\hline Solyc09g083410.2.1 & 70 & 1 & 1 & 1 & 1 & 3.9 & 70.24 \\
\hline Solyc03g005220.2.1 & 70 & 1 & 1 & 1 & 1 & 16.2 & 70.14 \\
\hline Solyc09g005400.2.1 & 70 & 2 & 2 & 1 & 1 & 9.3 & 44.91 \\
\hline Solyc06g065520.2.1 & 70 & 2 & 1 & 2 & 1 & 6.1 & 59.83 \\
\hline Solyc02g094180.2.1 & 70 & 2 & 2 & 2 & 2 & 10.8 & 55.6 \\
\hline Solyc08g079920.1.1 & 70 & 3 & 2 & 3 & 2 & 7.5 & 49.5 \\
\hline Solyc08g067100.2.1 & 69 & 1 & 1 & 1 & 1 & 4.2 & 69.28 \\
\hline Solyc02g086740.1.1 & 69 & 1 & 1 & 1 & 1 & 9.7 & 68.84 \\
\hline Solyc02g082200.2.1 & 69 & 1 & 1 & 1 & 1 & 10.2 & 68.75 \\
\hline Solyc01g088700.2.1 & 69 & 1 & 1 & 1 & 1 & 1 & 68.72 \\
\hline Solyc07g053970.2.1 & 69 & 1 & 1 & 1 & 1 & 2.7 & 68.54 \\
\hline Solyc05g056390.2.1 & 69 & 4 & 3 & 2 & 2 & 27.8 & 43.21 \\
\hline Solyc06g007200.2.1 & 68 & 1 & 1 & 1 & 1 & 4.4 & 68.33 \\
\hline Solyc12g044850.1.1 & 68 & 1 & 1 & 1 & 1 & 14.1 & 68.18 \\
\hline Solyc01g099830.2.1 & 68 & 2 & 1 & 2 & 1 & 28.8 & 57.03 \\
\hline Solyc09g010400.2.1 & 68 & 2 & 1 & 2 & 1 & 20.7 & 68.09 \\
\hline Solyc01g090120.2.1 & 68 & 1 & 1 & 1 & 1 & 10.1 & 67.84 \\
\hline Solyc07g032250.2.1 & 68 & 2 & 2 & 1 & 1 & 5.6 & 45.37 \\
\hline Solyc02g085350.2.1 & 68 & 2 & 2 & 2 & 2 & 4.5 & 46.66 \\
\hline Solyc05g051510.2.1 & 68 & 2 & 2 & 2 & 2 & 14.4 & 52.61 \\
\hline Solyc06g073700.2.1 & 67 & 1 & 1 & 1 & 1 & 16.3 & 67.14 \\
\hline Solyc01g079420.2.1 & 67 & 1 & 1 & 1 & 1 & 12.8 & 66.88 \\
\hline Solyc06g074780.1.1 & 67 & 6 & 5 & 2 & 1 & 16.8 & 43.53 \\
\hline Solyc07g041900.2.1 & 67 & 2 & 1 & 1 & 1 & 4.5 & 61.95 \\
\hline Solyc04g078540.2.1 & 67 & 4 & 2 & 4 & 2 & 11.9 & 43.28 \\
\hline Solyc02g091490.2.1 & 67 & 3 & 2 & 3 & 2 & 9.8 & 57.83 \\
\hline Solyc04g015830.2.1 & 67 & 2 & 2 & 2 & 2 & 3.3 & 54.34 \\
\hline Solyc04g076880.2.1 & 66 & 1 & 1 & 1 & 1 & 2.3 & 66.49 \\
\hline Solyc03g095190.2.1 & 66 & 1 & 1 & 1 & 1 & 8 & 65.95 \\
\hline Solyc07g047790.2.1 & 66 & 2 & 1 & 2 & 1 & 5.8 & 59.32 \\
\hline Solyc06g007670.2.1 & 66 & 2 & 2 & 1 & 1 & 4.7 & 50.42 \\
\hline Solyc03g118040.2.1 & 66 & 6 & 2 & 5 & 2 & 15.2 & 40.46 \\
\hline Solyc04g007750.2.1 & 66 & 4 & 2 & 3 & 2 & 21.1 & 51.92 \\
\hline Solyc02g084710.2.1 & 66 & 2 & 2 & 2 & 2 & 21.2 & 60.08 \\
\hline Solyc10g005890.2.1 & 66 & 2 & 2 & 2 & 2 & 8.4 & 58.78 \\
\hline Solyc01g073640.2.1 & 65 & 4 & 2 & 1 & 1 & 7.7 & 32.07 \\
\hline Solyc02g069090.2.1 & 65 & 1 & 1 & 1 & 1 & 6.2 & 65.43 \\
\hline Solyc09g007250.2.1 & 65 & 2 & 2 & 1 & 1 & 3.9 & 44.47 \\
\hline Solyc09g018450.2.1 & 65 & 1 & 1 & 1 & 1 & 1.8 & 65.2 \\
\hline
\end{tabular}


Supplemental Table 3. Continued.

\begin{tabular}{|c|c|c|c|c|c|c|c|}
\hline Accession $^{y}$ & $\begin{array}{l}\text { Protein } \\
\text { score }^{\mathrm{x}}\end{array}$ & $\begin{array}{c}\text { Total } \\
\text { matches (no.) }\end{array}$ & $\begin{array}{c}\text { Unique } \\
\text { matches (no.) }^{\mathrm{v}}\end{array}$ & $\begin{array}{c}\text { Total } \\
\text { sequences (no.) }{ }^{\mathrm{u}}\end{array}$ & $\begin{array}{c}\text { Unique } \\
\text { sequences (no.) }^{\mathrm{t}}\end{array}$ & $\begin{array}{c}\text { Protein } \\
\text { coverage }(\%)^{\mathrm{s}}\end{array}$ & $\begin{array}{c}\text { Highest } \\
\text { peptide score }\end{array}$ \\
\hline 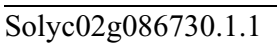 & 65 & 1 & 1 & 1 & 1 & 9.5 & 65.01 \\
\hline Solyc09g075150.2.1 & 65 & 2 & 1 & 2 & 1 & 29 & 57.03 \\
\hline Solyc03g097070.2.1 & 65 & 1 & 1 & 1 & 1 & 5.3 & 64.92 \\
\hline Solyc04g074410.1.1 & 65 & 1 & 1 & 1 & 1 & 6.7 & 64.85 \\
\hline Solyc07g006790.2.1 & 65 & 2 & 1 & 1 & 1 & 3.1 & 60.07 \\
\hline Solyc10g079830.1.1 & 65 & 1 & 1 & 1 & 1 & 13.1 & 64.69 \\
\hline Solyc11g067230.1.1 & 65 & 1 & 1 & 1 & 1 & 4.4 & 64.64 \\
\hline Solyc01g107590.2.1 & 65 & 2 & 2 & 2 & 2 & 12.3 & 43.54 \\
\hline Solyc11g006070.1.1 & 64 & 2 & 1 & 2 & 1 & 21.6 & 49.83 \\
\hline Solyc01g008370.2.1 & 64 & 2 & 2 & 2 & 2 & 13.2 & 49.6 \\
\hline Solyc12g014250.1.1 & 64 & 5 & 3 & 4 & 2 & 7.8 & 39.2 \\
\hline Solyc06g068090.2.1 & 64 & 2 & 2 & 2 & 2 & 4.3 & 50.34 \\
\hline Solyc10g086010.1.1 & 64 & 2 & 2 & 2 & 2 & 8.3 & 50.26 \\
\hline Solyc07g008240.2.1 & 64 & 2 & 2 & 2 & 2 & 17.8 & 46.23 \\
\hline Solyc09g082520.2.1 & 64 & 2 & 2 & 2 & 2 & 12.7 & 49.9 \\
\hline Solyc01g109540.2.1 & 64 & 3 & 3 & 3 & 3 & 5.6 & 42.72 \\
\hline Solyc03g098760.1.1 & 63 & 1 & 1 & 1 & 1 & 9.9 & 63.47 \\
\hline Solyc09g092430.2.1 & 63 & 1 & 1 & 1 & 1 & 5.1 & 63.41 \\
\hline Solyc02g065300.1.1 & 63 & 1 & 1 & 1 & 1 & 1.8 & 63.32 \\
\hline Solyc09g025240.2.1 & 63 & 1 & 1 & 1 & 1 & 6 & 62.73 \\
\hline Solyc09g064720.2.1 & 63 & 1 & 1 & 1 & 1 & 7.1 & 62.52 \\
\hline Solyc09g075670.1.1 & 63 & 1 & 1 & 1 & 1 & 6 & 62.52 \\
\hline Solyc12g088720.1.1 & 63 & 3 & 2 & 3 & 2 & 9 & 43.52 \\
\hline Solyc09g090700.1.1 & 63 & 2 & 2 & 2 & 2 & 8.8 & 48.36 \\
\hline Solyc01g111710.2.1 & 63 & 3 & 3 & 2 & 2 & 7.4 & 47.09 \\
\hline Solyc12g056250.1.1 & 63 & 2 & 2 & 2 & 2 & 11 & 55.97 \\
\hline Solyc04g082460.2.1 & 63 & 2 & 2 & 2 & 2 & 8.9 & 46.45 \\
\hline Solyc06g050550.2.1 & 62 & 1 & 1 & 1 & 1 & 3.7 & 62.3 \\
\hline Solyc04g054990.2.1 & 62 & 1 & 1 & 1 & 1 & 9.3 & 61.74 \\
\hline Solyc06g050440.2.1 & 62 & 4 & 2 & 3 & 2 & 16.9 & 41.34 \\
\hline Solyc08g077900.2.1 & 62 & 2 & 2 & 2 & 2 & 12.6 & 40.64 \\
\hline Solyc04g005160.1.1 & 62 & 4 & 4 & 3 & 3 & 8.7 & 41.81 \\
\hline Solyc08g082430.2.1 & 61 & 3 & 2 & 2 & 1 & 7.6 & 42.72 \\
\hline Solyc05g006750.2.1 & 61 & 1 & 1 & 1 & 1 & 7.4 & 61.31 \\
\hline Solyc02g068640.2.1 & 61 & 1 & 1 & 1 & 1 & 6.5 & 61.23 \\
\hline Solyc09g090010.2.1 & 61 & 1 & 1 & 1 & 1 & 10.3 & 61.2 \\
\hline Solyc08g014000.2.1 & 61 & 4 & 2 & 3 & 2 & 5.3 & 50.85 \\
\hline Solyc03g096000.2.1 & 61 & 2 & 2 & 2 & 2 & 1.6 & 53.36 \\
\hline Solyc01g098000.2.1 & 61 & 2 & 2 & 2 & 2 & 20.3 & 44.18 \\
\hline Solyc10g080970.1.1 & 61 & 3 & 2 & 3 & 2 & 14.7 & 40.73 \\
\hline Solyc05g053940.2.1 & 61 & 2 & 2 & 2 & 2 & 17.2 & 54.49 \\
\hline Solyc01g028810.2.1 & 61 & 4 & 2 & 4 & 2 & 8.3 & 55.75 \\
\hline Solyc06g069470.2.1 & 60 & 1 & 1 & 1 & 1 & 4.3 & 60.44 \\
\hline Solyc01g079940.2.1 & 60 & 1 & 1 & 1 & 1 & 5.1 & 60.23 \\
\hline Solyc02g021400.1.1 & 60 & 2 & 2 & 1 & 1 & 18.5 & 47.88 \\
\hline Solyc01g088080.2.1 & 60 & 2 & 2 & 1 & 1 & 3.5 & 49.11 \\
\hline Solyc01g007740.2.1 & 60 & 1 & 1 & 1 & 1 & 6 & 59.69 \\
\hline Solyc09g059040.2.1 & 60 & 2 & 1 & 2 & 1 & 11.6 & 49.15 \\
\hline Solyc06g008260.2.1 & 60 & 3 & 3 & 2 & 2 & 14.9 & 42.18 \\
\hline Solyc10g007070.2.1 & 60 & 2 & 2 & 2 & 2 & 10.6 & 49.13 \\
\hline Solyc05g012070.2.1 & 60 & 4 & 3 & 3 & 2 & 14.9 & 42.67 \\
\hline Solyc07g065490.2.1 & 60 & 2 & 2 & 2 & 2 & 4.4 & 45.99 \\
\hline Solyc03g083520.2.1 & 60 & 3 & 2 & 3 & 2 & 26.7 & 43.3 \\
\hline Solyc02g090210.2.1 & 59 & 1 & 1 & 1 & 1 & 4.6 & 59.35 \\
\hline Solyc02g082250.2.1 & 59 & 1 & 1 & 1 & 1 & 4.4 & 59.26 \\
\hline Solyc03g123610.2.1 & 59 & 1 & 1 & 1 & 1 & 3.3 & 59.2 \\
\hline Solyc10g005060.2.1 & 59 & 1 & 1 & 1 & 1 & 4.7 & 59.09 \\
\hline
\end{tabular}


Supplemental Table 3. Continued.

\begin{tabular}{|c|c|c|c|c|c|c|c|}
\hline Accession $^{y}$ & $\begin{array}{l}\text { Protein } \\
\text { score }^{\mathrm{x}}\end{array}$ & $\begin{array}{c}\text { Total } \\
\text { matches (no.) }\end{array}$ & $\begin{array}{c}\text { Unique } \\
\text { matches (no.) }^{\mathrm{v}}\end{array}$ & $\begin{array}{c}\text { Total } \\
\text { sequences }(\text { no. })^{\mathrm{u}}\end{array}$ & $\begin{array}{c}\text { Unique } \\
\text { sequences (no.) }^{\mathrm{t}}\end{array}$ & $\begin{array}{c}\text { Protein } \\
\text { coverage }(\%)^{\mathrm{s}}\end{array}$ & $\begin{array}{c}\text { Highest } \\
\text { peptide score }\end{array}$ \\
\hline $\begin{array}{l}\text { Solyc10g079610.1.1 } \\
\end{array}$ & 59 & 1 & 1 & 1 & 1 & 4.6 & 59.02 \\
\hline Solyc01g111660.2.1 & 59 & 1 & 1 & 1 & 1 & 6 & 58.76 \\
\hline Solyc10g082030.1.1 & 59 & 1 & 1 & 1 & 1 & 6.4 & 58.72 \\
\hline Solyc01g111150.2.1 & 59 & 1 & 1 & 1 & 1 & 5.8 & 58.67 \\
\hline Solyc01g097870.2.1 & 59 & 2 & 2 & 2 & 2 & 19.5 & 40.1 \\
\hline Solyc02g085050.2.1 & 58 & 1 & 1 & 1 & 1 & 6.7 & 58.36 \\
\hline Solyc08g075700.2.1 & 58 & 1 & 1 & 1 & 1 & 11.7 & 58.21 \\
\hline Solyc02g091970.2.1 & 58 & 1 & 1 & 1 & 1 & 4.2 & 58.17 \\
\hline Solyc01g088610.2.1 & 58 & 1 & 1 & 1 & 1 & 14.8 & 57.73 \\
\hline Solyc08g066740.2.1 & 58 & 1 & 1 & 1 & 1 & 10.5 & 57.59 \\
\hline Solyc08g068310.2.1 & 58 & 1 & 1 & 1 & 1 & 3.8 & 57.58 \\
\hline Solyc09g011660.2.1 & 58 & 2 & 2 & 2 & 2 & 21.3 & 45.77 \\
\hline Solyc01g079610.2.1 & 58 & 3 & 3 & 3 & 3 & 14.2 & 35.94 \\
\hline Solyc07g066580.2.1 & 57 & 1 & 1 & 1 & 1 & 7 & 57.39 \\
\hline Solyc01g080220.2.1 & 57 & 1 & 1 & 1 & 1 & 8.8 & 57.28 \\
\hline Solyc04g072000.2.1 & 57 & 1 & 1 & 1 & 1 & 7.6 & 57.15 \\
\hline Solyc05g018700.2.1 & 57 & 1 & 1 & 1 & 1 & 3.2 & 57.08 \\
\hline Solyc10g081180.1.1 & 57 & 2 & 1 & 1 & 1 & 9.5 & 47.95 \\
\hline Solyc06g083030.2.1 & 57 & 1 & 1 & 1 & 1 & 3.8 & 56.91 \\
\hline Solyc02g068150.2.1 & 57 & 1 & 1 & 1 & 1 & 15.4 & 56.81 \\
\hline Solyc02g088690.2.1 & 57 & 2 & 2 & 2 & 2 & 15.2 & 49.59 \\
\hline Solyc11g069150.1.1 & 57 & 2 & 2 & 2 & 2 & 11.8 & 41.32 \\
\hline Solyc05g054710.2.1 & 56 & 2 & 1 & 1 & 1 & 2.5 & 48.39 \\
\hline Solyc09g014790.2.1 & 56 & 1 & 1 & 1 & 1 & 2.6 & 56.46 \\
\hline Solyc04g005350.2.1 & 56 & 1 & 1 & 1 & 1 & 16.8 & 56.31 \\
\hline Solyc11g066130.1.1 & 56 & 3 & 2 & 1 & 1 & 5.6 & 31.6 \\
\hline Solyc12g011160.1.1 & 56 & 1 & 1 & 1 & 1 & 4.2 & 56.16 \\
\hline Solyc09g018790.2.1 & 56 & 1 & 1 & 1 & 1 & 6.3 & 56.12 \\
\hline Solyc06g083730.2.1 & 56 & 1 & 1 & 1 & 1 & 3.5 & 56.11 \\
\hline Solyc06g034120.2.1 & 56 & 1 & 1 & 1 & 1 & 4.9 & 56.04 \\
\hline Solyc02g078040.2.1 & 56 & 1 & 1 & 1 & 1 & 6.6 & 56.01 \\
\hline Solyc01g081600.2.1 & 56 & 1 & 1 & 1 & 1 & 14.9 & 55.91 \\
\hline Solyc07g055690.1.1 & 56 & 2 & 1 & 2 & 1 & 6.5 & 51.21 \\
\hline Solyc02g071150.2.1 & 56 & 2 & 2 & 1 & 1 & 10.9 & 44.19 \\
\hline Solyc05g052310.2.1 & 56 & 2 & 2 & 2 & 2 & 13.2 & 42.21 \\
\hline Solyc07g055210.2.1 & 56 & 2 & 2 & 2 & 2 & 7.1 & 46.99 \\
\hline Solyc07g042570.2.1 & 56 & 2 & 2 & 2 & 2 & 12.4 & 40.63 \\
\hline Solyc05g013990.2.1 & 55 & 1 & 1 & 1 & 1 & 2.6 & 55.48 \\
\hline Solyc01g097300.2.1 & 55 & 1 & 1 & 1 & 1 & 15.6 & 55.26 \\
\hline Solyc03g044010.2.1 & 55 & 1 & 1 & 1 & 1 & 7.7 & 55.2 \\
\hline Solyc08g007600.1.1 & 55 & 1 & 1 & 1 & 1 & 2.4 & 55.09 \\
\hline Solyc11g007200.1.1 & 55 & 1 & 1 & 1 & 1 & 15.9 & 55.08 \\
\hline Solyc04g080880.2.1 & 55 & 1 & 1 & 1 & 1 & 2.2 & 54.97 \\
\hline Solyc10g008120.2.1 & 55 & 1 & 1 & 1 & 1 & 5.8 & 54.68 \\
\hline Solyc09g098150.2.1 & 55 & 3 & 2 & 2 & 2 & 5 & 38.22 \\
\hline Solyc09g010460.2.1 & 55 & 2 & 2 & 2 & 2 & 2.4 & 41.41 \\
\hline Solyc10g037980.1.1 & 54 & 2 & 2 & 1 & 1 & 11.4 & 37.43 \\
\hline Solyc06g071050.2.1 & 54 & 1 & 1 & 1 & 1 & 5.5 & 54.19 \\
\hline Solyc07g008560.2.1 & 54 & 2 & 2 & 2 & 2 & 4.4 & 43.17 \\
\hline Solyc10g051390.1.1 & 54 & 2 & 2 & 2 & 2 & 25.4 & 38.78 \\
\hline Solyc09g092530.2.1 & 53 & 1 & 1 & 1 & 1 & 6.1 & 53.33 \\
\hline Solyc03g019690.1.1 & 53 & 1 & 1 & 1 & 1 & 7.8 & 53.22 \\
\hline Solyc02g086830.2.1 & 53 & 1 & 1 & 1 & 1 & 5.3 & 52.77 \\
\hline Solyc01g105060.2.1 & 53 & 2 & 2 & 2 & 2 & 11.6 & 44.39 \\
\hline Solyc06g051010.1.1 & 53 & 2 & 2 & 2 & 2 & 5.1 & 39.71 \\
\hline Solyc02g083710.2.1 & 53 & 2 & 2 & 2 & 2 & 11.4 & 39.4 \\
\hline Solyc10g080710.1.1 & 52 & 1 & 1 & 1 & 1 & 2.6 & 52.32 \\
\hline
\end{tabular}


Supplemental Table 3. Continued.

\begin{tabular}{|c|c|c|c|c|c|c|c|}
\hline Accession $^{y}$ & $\begin{array}{l}\text { Protein } \\
\text { score }^{\mathrm{x}}\end{array}$ & $\begin{array}{c}\text { Total } \\
\text { matches (no.) }\end{array}$ & $\begin{array}{c}\text { Unique } \\
\text { matches (no.) }\end{array}$ & $\begin{array}{c}\text { Total } \\
\text { sequences }(\text { no. })^{\mathrm{u}}\end{array}$ & $\begin{array}{c}\text { Unique } \\
\text { sequences (no.) }\end{array}$ & $\begin{array}{c}\text { Protein } \\
\text { coverage }(\%)^{\mathrm{s}}\end{array}$ & $\begin{array}{c}\text { Highest } \\
\text { peptide score }\end{array}$ \\
\hline 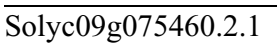 & 52 & 1 & 1 & 1 & 1 & 3.5 & 52.16 \\
\hline Solyc11g069270.1.1 & 52 & 2 & 2 & 2 & 2 & 4.5 & 37.31 \\
\hline Solyc03g123830.2.1 & 52 & 2 & 2 & 2 & 2 & 4 & 42.49 \\
\hline Solyc04g045340.2.1 & 52 & 4 & 3 & 4 & 3 & 13.7 & 40.6 \\
\hline Solyc04g008810.2.1 & 51 & 1 & 1 & 1 & 1 & 11.7 & 51.46 \\
\hline Solyc01g109850.2.1 & 51 & 2 & 1 & 2 & 1 & 6.5 & 45.8 \\
\hline Solyc04g078380.1.1 & 51 & 2 & 1 & 2 & 1 & 27.6 & 36.59 \\
\hline Solyc10g077030.1.1 & 51 & 1 & 1 & 1 & 1 & 6.8 & 51.1 \\
\hline Solyc05g009600.2.1 & 51 & 2 & 1 & 2 & 1 & 5.5 & 42.76 \\
\hline Solyc06g069570.2.1 & 51 & 1 & 1 & 1 & 1 & 5.2 & 50.85 \\
\hline Solyc08g041870.2.1 & 51 & 1 & 1 & 1 & 1 & 3 & 50.65 \\
\hline Solyc01g111060.2.1 & 51 & 1 & 1 & 1 & 1 & 4.9 & 50.56 \\
\hline Solyc03g121070.2.1 & 51 & 2 & 2 & 2 & 2 & 6.8 & 46.23 \\
\hline Solyc09g083080.2.1 & 50 & 1 & 1 & 1 & 1 & 2.9 & 50.42 \\
\hline Solyc04g005030.2.1 & 50 & 1 & 1 & 1 & 1 & 5.2 & 50.23 \\
\hline Solyc06g008170.2.1 & 50 & 1 & 1 & 1 & 1 & 12.9 & 50.08 \\
\hline Solyc05g052150.2.1 & 50 & 1 & 1 & 1 & 1 & 17.2 & 49.81 \\
\hline Solyc11g040390.1.1 & 50 & 1 & 1 & 1 & 1 & 2.2 & 49.79 \\
\hline Solyc06g007320.2.1 & 50 & 1 & 1 & 1 & 1 & 1.6 & 49.77 \\
\hline Solyc02g083590.2.1 & 50 & 1 & 1 & 1 & 1 & 4.1 & 49.75 \\
\hline Solyc03g097790.2.1 & 50 & 1 & 1 & 1 & 1 & 5.3 & 49.73 \\
\hline Solyc03g118020.2.1 & 50 & 3 & 1 & 2 & 1 & 3.3 & 47.8 \\
\hline Solyc05g012080.2.1 & 50 & 1 & 1 & 1 & 1 & 15 & 49.71 \\
\hline Solyc03g111230.2.1 & 50 & 1 & 1 & 1 & 1 & 6.7 & 49.52 \\
\hline Solyc05g015390.2.1 & 50 & 2 & 2 & 2 & 2 & 13 & 36.99 \\
\hline Solyc03g097190.2.1 & 50 & 2 & 2 & 2 & 2 & 2.8 & 34.68 \\
\hline Solyc06g073280.2.1 & 50 & 2 & 2 & 2 & 2 & 6.1 & 42.75 \\
\hline Solyc09g075010.2.1 & 49 & 2 & 1 & 1 & 1 & 5.8 & 40.95 \\
\hline Solyc11g008870.1.1 & 49 & 2 & 1 & 2 & 1 & 5.2 & 36.39 \\
\hline Solyc05g053140.2.1 & 49 & 2 & 1 & 2 & 1 & 6.5 & 41.86 \\
\hline Solyc06g060760.2.1 & 49 & 1 & 1 & 1 & 1 & 6.4 & 49.36 \\
\hline Solyc02g084360.2.1 & 49 & 1 & 1 & 1 & 1 & 10.9 & 49.32 \\
\hline Solyc03g043960.2.1 & 49 & 2 & 1 & 2 & 1 & 19 & 41.62 \\
\hline Solyc05g052470.2.1 & 49 & 3 & 2 & 2 & 1 & 9.7 & 37.45 \\
\hline Solyc00g140060.2.1 & 49 & 1 & 1 & 1 & 1 & 8.7 & 49.14 \\
\hline Solyc08g081780.1.1 & 49 & 1 & 1 & 1 & 1 & 16.9 & 48.86 \\
\hline Solyc10g081120.1.1 & 49 & 1 & 1 & 1 & 1 & 2.7 & 48.84 \\
\hline Solyc08g075390.2.1 & 49 & 1 & 1 & 1 & 1 & 2.4 & 48.63 \\
\hline Solyc01g096450.2.1 & 49 & 3 & 2 & 2 & 2 & 5.6 & 35.7 \\
\hline Solyc05g018810.2.1 & 49 & 2 & 2 & 2 & 2 & 7.2 & 39.61 \\
\hline Solyc01g008330.2.1 & 49 & 2 & 2 & 2 & 2 & 7.1 & 40.42 \\
\hline Solyc07g005600.2.1 & 48 & 1 & 1 & 1 & 1 & 2.3 & 48.21 \\
\hline Solyc11g039830.1.1 & 48 & 1 & 1 & 1 & 1 & 1.9 & 48.17 \\
\hline Solyc06g062950.1.1 & 48 & 1 & 1 & 1 & 1 & 1.9 & 48.09 \\
\hline Solyc01g105370.2.1 & 48 & 1 & 1 & 1 & 1 & 5.3 & 47.95 \\
\hline Solyc08g075780.2.1 & 48 & 2 & 1 & 1 & 1 & 15.3 & 44.49 \\
\hline Solyc04g010240.2.1 & 48 & 2 & 2 & 1 & 1 & 10.6 & 37.68 \\
\hline Solyc02g081170.2.1 & 48 & 1 & 1 & 1 & 1 & 4 & 47.78 \\
\hline Solyc08g079070.2.1 & 48 & 1 & 1 & 1 & 1 & 4.3 & 47.74 \\
\hline Solyc05g009980.2.1 & 48 & 1 & 1 & 1 & 1 & 3.2 & 47.67 \\
\hline Solyc09g083370.2.1 & 48 & 1 & 1 & 1 & 1 & 11.3 & 47.64 \\
\hline Solyc01g007330.2.1 & 48 & 1 & 1 & 1 & 1 & 4 & 47.59 \\
\hline Solyc07g064980.2.1 & 47 & 1 & 1 & 1 & 1 & 3.6 & 47.3 \\
\hline Solyc08g082280.2.1 & 47 & 1 & 1 & 1 & 1 & 2.7 & 47.2 \\
\hline Solyc01g103750.2.1 & 47 & 1 & 1 & 1 & 1 & 5.6 & 47.04 \\
\hline Solyc01g005980.2.1 & 47 & 1 & 1 & 1 & 1 & 6 & 46.85 \\
\hline Solyc12g008940.1.1 & 47 & 2 & 1 & 2 & 1 & 7 & 39.61 \\
\hline
\end{tabular}


Supplemental Table 3. Continued.

\begin{tabular}{|c|c|c|c|c|c|c|c|}
\hline Accession $^{\mathrm{y}}$ & $\begin{array}{l}\text { Protein } \\
\text { score }^{\mathrm{x}}\end{array}$ & $\begin{array}{c}\text { Total } \\
\text { matches (no.) }\end{array}$ & $\begin{array}{c}\text { Unique } \\
\text { matches (no.) }\end{array}$ & $\begin{array}{c}\text { Total } \\
\text { sequences }(\text { no. })^{\mathrm{u}}\end{array}$ & $\begin{array}{c}\text { Unique } \\
\text { sequences (no.) } \\
\end{array}$ & $\begin{array}{c}\text { Protein } \\
\text { coverage }(\%)^{\mathrm{s}}\end{array}$ & $\begin{array}{c}\text { Highest } \\
\text { peptide score }\end{array}$ \\
\hline Solyc12g008370.1.1 & 47 & 1 & 1 & 1 & 1 & 3.6 & 46.63 \\
\hline Solyc02g082830.1.1 & 47 & 2 & 2 & 2 & 2 & 7.4 & 36.95 \\
\hline Solyc05g053780.2.1 & 47 & 2 & 2 & 2 & 2 & 16.8 & 36.34 \\
\hline Solyc02g092440.2.1 & 47 & 2 & 2 & 2 & 2 & 14.1 & 41.56 \\
\hline Solyc02g077220.2.1 & 47 & 2 & 2 & 2 & 2 & 12.5 & 36.94 \\
\hline Solyc07g064810.2.1 & 46 & 1 & 1 & 1 & 1 & 2.7 & 46.49 \\
\hline Solyc06g005810.2.1 & 46 & 1 & 1 & 1 & 1 & 8.3 & 46.36 \\
\hline Solyc01g110120.2.1 & 46 & 1 & 1 & 1 & 1 & 1.7 & 46.34 \\
\hline Solyc04g079440.2.1 & 46 & 1 & 1 & 1 & 1 & 4.1 & 46.32 \\
\hline Solyc08g014340.2.1 & 46 & 1 & 1 & 1 & 1 & 8 & 46.15 \\
\hline Solyc01g106430.2.1 & 46 & 1 & 1 & 1 & 1 & 6.2 & 46.12 \\
\hline Solyc01g005250.2.1 & 46 & 1 & 1 & 1 & 1 & 5.2 & 45.93 \\
\hline Solyc05g054590.2.1 & 46 & 2 & 1 & 2 & 1 & 13.1 & 38.07 \\
\hline Solyc07g049360.2.1 & 46 & 1 & 1 & 1 & 1 & 15.6 & 45.88 \\
\hline Solyc01g112080.2.1 & 46 & 2 & 1 & 2 & 1 & 8.7 & 32.41 \\
\hline Solyc10g079500.1.1 & 46 & 1 & 1 & 1 & 1 & 3 & 45.69 \\
\hline Solyc04g007120.2.1 & 46 & 2 & 2 & 2 & 2 & 5.9 & 36.06 \\
\hline Solyc05g056400.2.1 & 46 & 5 & 2 & 3 & 2 & 6.4 & 35.15 \\
\hline Solyc02g069590.2.1 & 45 & 2 & 1 & 2 & 1 & 14.6 & 39.6 \\
\hline Solyc11g005620.1.1 & 45 & 1 & 1 & 1 & 1 & 4.9 & 45.32 \\
\hline Solyc01g087540.2.1 & 45 & 1 & 1 & 1 & 1 & 4.4 & 45.24 \\
\hline Solyc04g079200.2.1 & 45 & 1 & 1 & 1 & 1 & 4.8 & 45.2 \\
\hline Solyc10g083120.1.1 & 45 & 2 & 1 & 1 & 1 & 8.2 & 39.01 \\
\hline Solyc06g083440.2.1 & 45 & 1 & 1 & 1 & 1 & 15.8 & 44.92 \\
\hline Solyc04g081400.2.1 & 45 & 1 & 1 & 1 & 1 & 3.4 & 44.9 \\
\hline Solyc04g016360.2.1 & 45 & 1 & 1 & 1 & 1 & 6 & 44.89 \\
\hline Solyc03g123730.2.1 & 45 & 2 & 1 & 1 & 1 & 3.5 & 39.84 \\
\hline Solyc03g116170.2.1 & 45 & 1 & 1 & 1 & 1 & 6.7 & 44.75 \\
\hline Solyc04g082590.2.1 & 45 & 1 & 1 & 1 & 1 & 6.5 & 44.73 \\
\hline Solyc03g115760.2.1 & 45 & 1 & 1 & 1 & 1 & 5 & 44.63 \\
\hline Solyc11g068540.1.1 & 45 & 1 & 1 & 1 & 1 & 6 & 44.52 \\
\hline Solyc01g079680.2.1 & 45 & 2 & 2 & 2 & 2 & 8.4 & 36.91 \\
\hline Solyc05g009030.2.1 & 45 & 2 & 2 & 2 & 2 & 6.4 & 38.54 \\
\hline Solyc02g079060.2.1 & 44 & 1 & 1 & 1 & 1 & 6.8 & 44.34 \\
\hline Solyc04g009550.2.1 & 44 & 1 & 1 & 1 & 1 & 6.7 & 44.23 \\
\hline Solyc10g086150.1.1 & 44 & 1 & 1 & 1 & 1 & 7.2 & 44.21 \\
\hline Solyc03g006680.2.1 & 44 & 2 & 1 & 2 & 1 & 11 & 41.66 \\
\hline Solyc02g094200.2.1 & 44 & 1 & 1 & 1 & 1 & 23.6 & 44.1 \\
\hline Solyc01g079820.2.1 & 44 & 1 & 1 & 1 & 1 & 6.3 & 44.03 \\
\hline Solyc10g078540.1.1 & 44 & 1 & 1 & 1 & 1 & 8.2 & 43.81 \\
\hline Solyc01g022750.2.1 & 44 & 1 & 1 & 1 & 1 & 9.8 & 43.68 \\
\hline Solyc03g120090.1.1 & 44 & 1 & 1 & 1 & 1 & 6.2 & 43.63 \\
\hline Solyc08g075690.2.1 & 44 & 2 & 1 & 2 & 1 & 33.3 & 38.9 \\
\hline Solyc07g008370.2.1 & 44 & 2 & 2 & 2 & 2 & 9.9 & 36.64 \\
\hline Solyc08g008050.2.1 & 43 & 2 & 2 & 1 & 1 & 4.9 & 32.9 \\
\hline Solyc01g097880.2.1 & 43 & 1 & 1 & 1 & 1 & 5.9 & 43.25 \\
\hline Solyc01g099900.2.1 & 43 & 1 & 1 & 1 & 1 & 5.9 & 43.13 \\
\hline Solyc12g096650.1.1 & 43 & 1 & 1 & 1 & 1 & 7 & 43.08 \\
\hline Solyc06g054250.2.1 & 43 & 1 & 1 & 1 & 1 & 5.3 & 42.92 \\
\hline Solyc01g090190.2.1 & 43 & 1 & 1 & 1 & 1 & 5.6 & 42.8 \\
\hline Solyc12g009960.1.1 & 43 & 1 & 1 & 1 & 1 & 1.9 & 42.67 \\
\hline Solyc02g071700.2.1 & 43 & 1 & 1 & 1 & 1 & 3.9 & 42.65 \\
\hline Solyc03g111840.2.1 & 43 & 1 & 1 & 1 & 1 & 5.1 & 42.6 \\
\hline Solyc11g040370.1.1 & 43 & 1 & 1 & 1 & 1 & 2.4 & 42.52 \\
\hline Solyc10g050890.1.1 & 43 & 3 & 3 & 3 & 3 & 8.4 & 38.31 \\
\hline Solyc09g098280.2.1 & 42 & 1 & 1 & 1 & 1 & 4.1 & 42.39 \\
\hline Solyc08g008210.2.1 & 42 & 3 & 1 & 3 & 1 & 15.8 & 30.61 \\
\hline
\end{tabular}


Supplemental Table 3. Continued.

\begin{tabular}{|c|c|c|c|c|c|c|c|}
\hline Accession $^{y}$ & $\begin{array}{l}\text { Protein } \\
\text { score }^{\mathrm{x}}\end{array}$ & $\begin{array}{c}\text { Total } \\
\text { matches (no.) }\end{array}$ & $\begin{array}{c}\text { Unique } \\
\text { matches (no.) }\end{array}$ & $\begin{array}{c}\text { Total } \\
\text { sequences }(\text { no. })^{\mathrm{u}}\end{array}$ & $\begin{array}{c}\text { Unique } \\
\text { sequences (no.) } \\
\end{array}$ & $\begin{array}{c}\text { Protein } \\
\text { coverage }(\%)^{\mathrm{s}}\end{array}$ & $\begin{array}{c}\text { Highest } \\
\text { peptide score }\end{array}$ \\
\hline Solyc11g011470.1.1 & 42 & 1 & 1 & 1 & 1 & 3.2 & 42.2 \\
\hline Solyc01g091220.2.1 & 42 & 1 & 1 & 1 & 1 & 8.6 & 42.03 \\
\hline Solyc11g039840.1.1 & 42 & 2 & 1 & 2 & 1 & 16.2 & 42.02 \\
\hline Solyc10g080320.1.1 & 42 & 1 & 1 & 1 & 1 & 3.6 & 42.01 \\
\hline Solyc02g083270.2.1 & 42 & 1 & 1 & 1 & 1 & 3.5 & 41.99 \\
\hline Solyc02g082350.2.1 & 42 & 1 & 1 & 1 & 1 & 2.9 & 41.9 \\
\hline Solyc06g067940.2.1 & 42 & 1 & 1 & 1 & 1 & 8.5 & 41.8 \\
\hline Solyc08g069040.2.1 & 42 & 1 & 1 & 1 & 1 & 5.1 & 41.8 \\
\hline Solyc01g097010.2.1 & 42 & 1 & 1 & 1 & 1 & 3.6 & 41.69 \\
\hline Solyc07g055060.2.1 & 42 & 3 & 1 & 3 & 1 & 4.9 & 31.97 \\
\hline Solyc08g077930.2.1 & 42 & 3 & 2 & 3 & 2 & 14.4 & 32.24 \\
\hline Solyc06g009400.2.1 & 42 & 3 & 2 & 2 & 2 & 12.6 & 33.46 \\
\hline Solyc04g071620.2.1 & 42 & 4 & 3 & 4 & 3 & 16.2 & 33.81 \\
\hline Solyc02g090090.2.1 & 41 & 1 & 1 & 1 & 1 & 3.4 & 41.49 \\
\hline Solyc04g082160.2.1 & 41 & 1 & 1 & 1 & 1 & 3.6 & 41.38 \\
\hline Solyc01g006510.2.1 & 41 & 1 & 1 & 1 & 1 & 4.8 & 41.29 \\
\hline Solyc09g013080.2.1 & 41 & 1 & 1 & 1 & 1 & 2 & 41.24 \\
\hline Solyc05g052140.2.1 & 41 & 2 & 1 & 2 & 1 & 24.7 & 29.07 \\
\hline Solyc01g100030.2.1 & 41 & 1 & 1 & 1 & 1 & 10.1 & 41.1 \\
\hline Solyc06g072220.1.1 & 41 & 1 & 1 & 1 & 1 & 5.7 & 41.1 \\
\hline Solyc05g013030.1.1 & 41 & 1 & 1 & 1 & 1 & 3.3 & 40.95 \\
\hline Solyc06g074820.2.1 & 41 & 1 & 1 & 1 & 1 & 5.6 & 40.89 \\
\hline Solyc06g007520.2.1 & 41 & 1 & 1 & 1 & 1 & 5.2 & 40.82 \\
\hline Solyc03g082580.2.1 & 41 & 1 & 1 & 1 & 1 & 4.4 & 40.64 \\
\hline Solyc06g065970.1.1 & 41 & 2 & 1 & 1 & 1 & 12.7 & 33.21 \\
\hline Solyc08g076990.2.1 & 40 & 1 & 1 & 1 & 1 & 3 & 40.38 \\
\hline Solyc03g115360.2.1 & 40 & 1 & 1 & 1 & 1 & 11.9 & 40.34 \\
\hline Solyc07g006640.2.1 & 40 & 1 & 1 & 1 & 1 & 8.8 & 40.32 \\
\hline Solyc05g017760.2.1 & 40 & 1 & 1 & 1 & 1 & 4.9 & 40.31 \\
\hline Solyc04g081740.2.1 & 40 & 1 & 1 & 1 & 1 & 3.9 & 40.28 \\
\hline Solyc06g083300.2.1 & 40 & 1 & 1 & 1 & 1 & 3.4 & 40.19 \\
\hline Solyc06g007710.2.1 & 40 & 2 & 1 & 2 & 1 & 10.2 & 32.55 \\
\hline Solyc01g066840.2.1 & 40 & 1 & 1 & 1 & 1 & 13.4 & 40.17 \\
\hline Solyc03g083610.2.1 & 40 & 1 & 1 & 1 & 1 & 7.2 & 40.13 \\
\hline Solyc12g006980.1.1 & 40 & 1 & 1 & 1 & 1 & 3.6 & 40.09 \\
\hline Solyc02g069790.2.1 & 40 & 1 & 1 & 1 & 1 & 4.6 & 40 \\
\hline Solyc11g066520.1.1 & 40 & 1 & 1 & 1 & 1 & 4.1 & 39.94 \\
\hline Solyc09g082650.2.1 & 40 & 1 & 1 & 1 & 1 & 5.8 & 39.79 \\
\hline Solyc01g008310.2.1 & 40 & 1 & 1 & 1 & 1 & 2.4 & 39.73 \\
\hline Solyc03g120720.2.1 & 40 & 1 & 1 & 1 & 1 & 3.2 & 39.73 \\
\hline Solyc12g018990.1.1 & 40 & 2 & 1 & 2 & 1 & 11.8 & 39.68 \\
\hline Solyc06g066060.2.1 & 40 & 2 & 2 & 2 & 2 & 5.4 & 31.76 \\
\hline Solyc10g086510.1.1 & 40 & 2 & 2 & 2 & 2 & 29 & 37.12 \\
\hline Solyc03g082600.2.1 & 39 & 1 & 1 & 1 & 1 & 8.4 & 39.46 \\
\hline Solyc03g113030.2.1 & 39 & 2 & 1 & 2 & 1 & 10.1 & 39.42 \\
\hline Solyc02g093630.2.1 & 39 & 1 & 1 & 1 & 1 & 2.6 & 39.24 \\
\hline Solyc01g007860.2.1 & 39 & 1 & 1 & 1 & 1 & 8.2 & 39.01 \\
\hline Solyc08g074790.2.1 & 39 & 1 & 1 & 1 & 1 & 6.1 & 39.01 \\
\hline Solyc02g014310.2.1 & 39 & 1 & 1 & 1 & 1 & 1.9 & 38.99 \\
\hline Solyc09g091470.2.1 & 39 & 1 & 1 & 1 & 1 & 2.8 & 38.84 \\
\hline Solyc02g063090.2.1 & 39 & 1 & 1 & 1 & 1 & 3.2 & 38.81 \\
\hline Solyc05g056490.2.1 & 39 & 1 & 1 & 1 & 1 & 8.6 & 38.8 \\
\hline Solyc12g042380.1.1 & 39 & 1 & 1 & 1 & 1 & 4.1 & 38.8 \\
\hline Solyc01g099890.2.1 & 39 & 1 & 1 & 1 & 1 & 11 & 38.69 \\
\hline Solyc03g121410.2.1 & 39 & 1 & 1 & 1 & 1 & 3.7 & 38.62 \\
\hline Solyc11g006350.1.1 & 39 & 1 & 1 & 1 & 1 & 4 & 38.59 \\
\hline Solyc01g110390.2.1 & 39 & 3 & 1 & 3 & 1 & 26.9 & 35.47 \\
\hline
\end{tabular}


Supplemental Table 3. Continued.

\begin{tabular}{|c|c|c|c|c|c|c|c|}
\hline Accession $^{y}$ & $\begin{array}{l}\text { Protein } \\
\text { score }^{\mathrm{x}}\end{array}$ & $\begin{array}{c}\text { Total } \\
\text { matches (no.) }\end{array}$ & $\begin{array}{c}\text { Unique } \\
\text { matches (no.) }\end{array}$ & $\begin{array}{c}\text { Total } \\
\text { sequences (no.) })^{\mathrm{u}}\end{array}$ & $\begin{array}{c}\text { Unique } \\
\text { sequences (no.) }\end{array}$ & $\begin{array}{c}\text { Protein } \\
\text { coverage }(\%)^{\mathrm{s}}\end{array}$ & $\begin{array}{c}\text { Highest } \\
\text { peptide score }\end{array}$ \\
\hline$\overline{\text { Solyc03g121330.2.1 }}$ & 38 & 1 & 1 & 1 & 1 & 9.1 & 38.39 \\
\hline Solyc01g066590.2.1 & 38 & 1 & 1 & 1 & 1 & 10.1 & 38.22 \\
\hline Solyc10g076350.1.1 & 38 & 1 & 1 & 1 & 1 & 8.8 & 38.06 \\
\hline Solyc12g008720.1.1 & 38 & 1 & 1 & 1 & 1 & 20.8 & 38.06 \\
\hline Solyc09g083210.2.1 & 38 & 1 & 1 & 1 & 1 & 2.9 & 37.99 \\
\hline Solyc01g009100.2.1 & 38 & 1 & 1 & 1 & 1 & 14.3 & 37.88 \\
\hline Solyc04g076790.2.1 & 38 & 1 & 1 & 1 & 1 & 2.9 & 37.84 \\
\hline Solyc11g072270.1.1 & 38 & 2 & 1 & 2 & 1 & 14.1 & 33.4 \\
\hline Solyc05g043430.2.1 & 38 & 1 & 1 & 1 & 1 & 10 & 37.81 \\
\hline Solyc11g007120.1.1 & 38 & 1 & 1 & 1 & 1 & 5.4 & 37.76 \\
\hline Solyc01g112280.2.1 & 38 & 1 & 1 & 1 & 1 & 2.9 & 37.72 \\
\hline Solyc02g093310.2.1 & 38 & 1 & 1 & 1 & 1 & 4.4 & 37.68 \\
\hline Solyc06g060420.2.1 & 38 & 1 & 1 & 1 & 1 & 4.7 & 37.6 \\
\hline Solyc10g006760.2.1 & 38 & 2 & 1 & 2 & 1 & 10.7 & 34.58 \\
\hline Solyc02g070310.2.1 & 38 & 2 & 2 & 2 & 2 & 18 & 34.63 \\
\hline Solyc02g082800.2.1 & 37 & 1 & 1 & 1 & 1 & 2.7 & 37.45 \\
\hline Solyc01g104950.2.1 & 37 & 1 & 1 & 1 & 1 & 1.5 & 37.43 \\
\hline Solyc03g114170.2.1 & 37 & 1 & 1 & 1 & 1 & 40 & 37.41 \\
\hline Solyc10g083290.1.1 & 37 & 2 & 1 & 2 & 1 & 6 & 31.75 \\
\hline Solyc09g075120.2.1 & 37 & 1 & 1 & 1 & 1 & 11.2 & 37.28 \\
\hline Solyc01g095000.2.1 & 37 & 1 & 1 & 1 & 1 & 5.3 & 37.21 \\
\hline Solyc08g067370.1.1 & 37 & 1 & 1 & 1 & 1 & 5.1 & 37.2 \\
\hline Solyc02g094470.2.1 & 37 & 1 & 1 & 1 & 1 & 3.6 & 37.16 \\
\hline Solyc02g081400.2.1 & 37 & 1 & 1 & 1 & 1 & 4.1 & 37.11 \\
\hline Solyc08g082700.2.1 & 37 & 1 & 1 & 1 & 1 & 3.7 & 37.09 \\
\hline Solyc02g090630.2.1 & 37 & 1 & 1 & 1 & 1 & 7.8 & 36.81 \\
\hline Solyc12g099570.1.1 & 37 & 1 & 1 & 1 & 1 & 44.4 & 36.79 \\
\hline Solyc05g055310.2.1 & 37 & 1 & 1 & 1 & 1 & 27.2 & 36.72 \\
\hline Solyc08g065640.2.1 & 37 & 1 & 1 & 1 & 1 & 10.3 & 36.69 \\
\hline Solyc07g017900.2.1 & 37 & 1 & 1 & 1 & 1 & 4.1 & 36.68 \\
\hline Solyc07g017400.2.1 & 37 & 1 & 1 & 1 & 1 & 5 & 36.6 \\
\hline Solyc12g096190.1.1 & 36 & 1 & 1 & 1 & 1 & 3.9 & 36.44 \\
\hline Solyc01g110450.2.1 & 36 & 1 & 1 & 1 & 1 & 4.5 & 36.43 \\
\hline Solyc01g009520.2.1 & 36 & 1 & 1 & 1 & 1 & 6.9 & 36.33 \\
\hline Solyc06g060790.1.1 & 36 & 1 & 1 & 1 & 1 & 5.9 & 36.25 \\
\hline Solyc11g012110.1.1 & 36 & 1 & 1 & 1 & 1 & 6.6 & 36.05 \\
\hline Solyc01g008080.2.1 & 36 & 2 & 1 & 2 & 1 & 29.1 & 32.14 \\
\hline Solyc04g011350.2.1 & 36 & 1 & 1 & 1 & 1 & 1.9 & 36.02 \\
\hline Solyc07g065090.1.1 & 36 & 1 & 1 & 1 & 1 & 4.9 & 35.99 \\
\hline Solyc06g035920.2.1 & 36 & 1 & 1 & 1 & 1 & 5.9 & 35.96 \\
\hline Solyc09g090520.2.1 & 36 & 1 & 1 & 1 & 1 & 2.3 & 35.93 \\
\hline Solyc04g076050.2.1 & 36 & 1 & 1 & 1 & 1 & 6.7 & 35.91 \\
\hline Solyc08g076540.2.1 & 36 & 1 & 1 & 1 & 1 & 11.4 & 35.75 \\
\hline Solyc02g088790.2.1 & 36 & 1 & 1 & 1 & 1 & 4.3 & 35.69 \\
\hline Solyc01g096040.2.1 & 36 & 1 & 1 & 1 & 1 & 3.3 & 35.64 \\
\hline Solyc08g029160.1.1 & 36 & 1 & 1 & 1 & 1 & 15 & 35.59 \\
\hline Solyc07g008350.2.1 & 35 & 1 & 1 & 1 & 1 & 4 & 35.49 \\
\hline Solyc02g092730.2.1 & 35 & 1 & 1 & 1 & 1 & 5.5 & 35.45 \\
\hline Solyc02g070500.1.1 & 35 & 1 & 1 & 1 & 1 & 10.2 & 35.44 \\
\hline Solyc06g076570.1.1 & 35 & 1 & 1 & 1 & 1 & 11 & 35.41 \\
\hline Solyc11g017070.1.1 & 35 & 1 & 1 & 1 & 1 & 9.5 & 35.41 \\
\hline Solyc01g058390.2.1 & 35 & 1 & 1 & 1 & 1 & 5.6 & 35.23 \\
\hline Solyc09g059620.2.1 & 35 & 1 & 1 & 1 & 1 & 7.1 & 35.09 \\
\hline Solyc01g008550.2.1 & 35 & 1 & 1 & 1 & 1 & 4.1 & 35.08 \\
\hline Solyc05g046340.1.1 & 35 & 1 & 1 & 1 & 1 & 5.6 & 35.08 \\
\hline Solyc08g081250.2.1 & 35 & 1 & 1 & 1 & 1 & 1.7 & 34.93 \\
\hline Solyc03g098720.2.1 & 35 & 2 & 2 & 1 & 1 & 5.2 & 32.63 \\
\hline
\end{tabular}


Supplemental Table 3. Continued.

\begin{tabular}{|c|c|c|c|c|c|c|c|}
\hline Accession $^{y}$ & $\begin{array}{l}\text { Protein } \\
\text { score }^{\mathrm{x}}\end{array}$ & $\begin{array}{c}\text { Total } \\
\text { matches (no.) }\end{array}$ & $\begin{array}{c}\text { Unique } \\
\text { matches (no.) }\end{array}$ & $\begin{array}{c}\text { Total } \\
\text { sequences (no.) })^{\mathrm{u}}\end{array}$ & $\begin{array}{c}\text { Unique } \\
\text { sequences (no.) }\end{array}$ & $\begin{array}{c}\text { Protein } \\
\text { coverage }(\%)^{\mathrm{s}}\end{array}$ & $\begin{array}{c}\text { Highest } \\
\text { peptide score }\end{array}$ \\
\hline 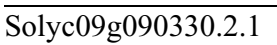 & 35 & 1 & 1 & 1 & 1 & 6.2 & 34.75 \\
\hline Solyc03g112650.2.1 & 35 & 1 & 1 & 1 & 1 & 5 & 34.73 \\
\hline Solyc06g065470.2.1 & 35 & 1 & 1 & 1 & 1 & 7.7 & 34.73 \\
\hline Solyc04g008760.1.1 & 35 & 1 & 1 & 1 & 1 & 4.2 & 34.54 \\
\hline Solyc01g009990.2.1 & 35 & 1 & 1 & 1 & 1 & 6 & 34.52 \\
\hline Solyc09g007640.2.1 & 34 & 1 & 1 & 1 & 1 & 2.8 & 34.44 \\
\hline Solyc03g114860.2.1 & 34 & 1 & 1 & 1 & 1 & 5.4 & 34.23 \\
\hline Solyc04g082140.2.1 & 34 & 1 & 1 & 1 & 1 & 3 & 34.22 \\
\hline Solyc01g067750.2.1 & 34 & 1 & 1 & 1 & 1 & 3.5 & 34.2 \\
\hline Solyc03g117940.2.1 & 34 & 1 & 1 & 1 & 1 & 5.2 & 34.15 \\
\hline Solyc10g081240.1.1 & 34 & 1 & 1 & 1 & 1 & 2.6 & 34.07 \\
\hline Solyc06g076890.1.1 & 34 & 1 & 1 & 1 & 1 & 11.8 & 34.06 \\
\hline Solyc12g006180.1.1 & 34 & 1 & 1 & 1 & 1 & 3.7 & 34.06 \\
\hline Solyc11g071610.1.1 & 34 & 1 & 1 & 1 & 1 & 1.3 & 33.97 \\
\hline Solyc01g100360.2.1 & 34 & 1 & 1 & 1 & 1 & 3.2 & 33.92 \\
\hline Solyc02g067080.2.1 & 34 & 1 & 1 & 1 & 1 & 5.3 & 33.92 \\
\hline Solyc02g070640.2.1 & 34 & 1 & 1 & 1 & 1 & 7.9 & 33.9 \\
\hline Solyc03g082480.2.1 & 34 & 1 & 1 & 1 & 1 & 7 & 33.89 \\
\hline Solyc08g081320.2.1 & 34 & 1 & 1 & 1 & 1 & 2.1 & 33.89 \\
\hline Solyc06g084090.2.1 & 34 & 1 & 1 & 1 & 1 & 4.9 & 33.85 \\
\hline Solyc05g053960.2.1 & 34 & 2 & 2 & 1 & 1 & 5.8 & 32.83 \\
\hline Solyc06g075340.2.1 & 34 & 1 & 1 & 1 & 1 & 1.2 & 33.54 \\
\hline Solyc02g070320.2.1 & 34 & 2 & 2 & 2 & 2 & 8.3 & 32.72 \\
\hline Solyc12g039120.1.1 & 33 & 1 & 1 & 1 & 1 & 11.9 & 33.26 \\
\hline Solyc06g076660.2.1 & 33 & 1 & 1 & 1 & 1 & 5.7 & 33.25 \\
\hline Solyc03g007670.2.1 & 33 & 1 & 1 & 1 & 1 & 3.5 & 33.19 \\
\hline Solyc01g081270.2.1 & 33 & 1 & 1 & 1 & 1 & 6.3 & 33.07 \\
\hline Solyc10g084120.1.1 & 33 & 2 & 1 & 2 & 1 & 10 & 33.04 \\
\hline Solyc03g119170.2.1 & 33 & 1 & 1 & 1 & 1 & 3.4 & 32.86 \\
\hline Solyc12g036790.1.1 & 33 & 1 & 1 & 1 & 1 & 9.1 & 32.85 \\
\hline Solyc07g042520.2.1 & 33 & 1 & 1 & 1 & 1 & 1.6 & 32.83 \\
\hline Solyc04g015620.2.1 & 33 & 2 & 1 & 2 & 1 & 7.8 & 32.77 \\
\hline Solyc07g032100.2.1 & 33 & 1 & 1 & 1 & 1 & 1.5 & 32.71 \\
\hline Solyc07g009330.2.1 & 33 & 1 & 1 & 1 & 1 & 12.6 & 32.63 \\
\hline Solyc12g008590.1.1 & 33 & 2 & 1 & 2 & 1 & 50 & 32.58 \\
\hline Solyc05g054090.2.1 & 33 & 1 & 1 & 1 & 1 & 20.8 & 32.54 \\
\hline Solyc01g094350.2.1 & 32 & 1 & 1 & 1 & 1 & 2.8 & 32.42 \\
\hline Solyc09g082990.2.1 & 32 & 1 & 1 & 1 & 1 & 4.3 & 32.38 \\
\hline Solyc03g097910.2.1 & 32 & 2 & 1 & 2 & 1 & 6.3 & 31.28 \\
\hline Solyc03g082940.2.1 & 32 & 1 & 1 & 1 & 1 & 2.9 & 32.31 \\
\hline Solyc01g106080.2.1 & 32 & 1 & 1 & 1 & 1 & 3.2 & 32.3 \\
\hline Solyc10g007480.2.1 & 32 & 1 & 1 & 1 & 1 & 3.1 & 32.3 \\
\hline Solyc03g120280.1.1 & 32 & 1 & 1 & 1 & 1 & 4.5 & 32.29 \\
\hline Solyc06g053460.1.1 & 32 & 1 & 1 & 1 & 1 & 8.9 & 32.22 \\
\hline Solyc02g091580.2.1 & 32 & 1 & 1 & 1 & 1 & 2.1 & 32.19 \\
\hline Solyc05g056540.2.1 & 32 & 1 & 1 & 1 & 1 & 2.3 & 32.19 \\
\hline Solyc06g019170.2.1 & 32 & 1 & 1 & 1 & 1 & 1.5 & 32.19 \\
\hline Solyc07g043310.2.1 & 32 & 1 & 1 & 1 & 1 & 2.7 & 32.11 \\
\hline Solyc07g053310.2.1 & 32 & 1 & 1 & 1 & 1 & 5.3 & 31.84 \\
\hline Solyc05g024410.2.1 & 32 & 1 & 1 & 1 & 1 & 4.9 & 31.8 \\
\hline Solyc00g323130.2.1 & 32 & 1 & 1 & 1 & 1 & 5.2 & 31.74 \\
\hline Solyc04g008310.1.1 & 32 & 1 & 1 & 1 & 1 & 2.6 & 31.65 \\
\hline Solyc01g079880.2.1 & 32 & 1 & 1 & 1 & 1 & 5.5 & 31.61 \\
\hline Solyc01g008360.2.1 & 32 & 1 & 1 & 1 & 1 & 13.8 & 31.59 \\
\hline Solyc02g092580.2.1 & 32 & 1 & 1 & 1 & 1 & 5.1 & 31.54 \\
\hline Solyc11g068430.1.1 & 31 & 1 & 1 & 1 & 1 & 16.1 & 31.47 \\
\hline Solyc01g010750.2.1 & 31 & 1 & 1 & 1 & 1 & 3.7 & 31.45 \\
\hline
\end{tabular}


Supplemental Table 3. Continued.

\begin{tabular}{|c|c|c|c|c|c|c|c|}
\hline Accession $^{y}$ & $\begin{array}{l}\text { Protein } \\
\text { score }^{\mathrm{x}}\end{array}$ & $\begin{array}{c}\text { Total } \\
\text { matches (no.) }\end{array}$ & $\begin{array}{c}\text { Unique } \\
\text { matches (no.) }\end{array}$ & $\begin{array}{c}\text { Total } \\
\text { sequences }(\text { no. })^{\mathrm{u}}\end{array}$ & $\begin{array}{c}\text { Unique } \\
\text { sequences (no.) }\end{array}$ & $\begin{array}{c}\text { Protein } \\
\text { coverage }(\%)^{\mathrm{s}}\end{array}$ & $\begin{array}{c}\text { Highest } \\
\text { peptide score }\end{array}$ \\
\hline Solyc11g062440.1.1 & 31 & 1 & 1 & 1 & 1 & 2.1 & 31.41 \\
\hline Solyc06g075810.2.1 & 31 & 1 & 1 & 1 & 1 & 11.2 & 31.4 \\
\hline Solyc07g049450.2.1 & 31 & 2 & 1 & 2 & 1 & 6.9 & 31.34 \\
\hline Solyc01g104680.2.1 & 31 & 1 & 1 & 1 & 1 & 5.9 & 31.29 \\
\hline Solyc11g011920.1.1 & 31 & 1 & 1 & 1 & 1 & 2.2 & 31.08 \\
\hline Solyc04g082780.2.1 & 31 & 1 & 1 & 1 & 1 & 5.6 & 31.07 \\
\hline Solyc07g047800.2.1 & 31 & 2 & 1 & 2 & 1 & 13.2 & 31.06 \\
\hline Solyc03g117600.2.1 & 31 & 1 & 1 & 1 & 1 & 3 & 30.93 \\
\hline Solyc03g122310.2.1 & 31 & 1 & 1 & 1 & 1 & 4.7 & 30.82 \\
\hline Solyc10g074980.1.1 & 31 & 1 & 1 & 1 & 1 & 2.4 & 30.53 \\
\hline Solyc09g007630.2.1 & 30 & 1 & 1 & 1 & 1 & 2.8 & 30.25 \\
\hline Solyc04g082710.2.1 & 30 & 1 & 1 & 1 & 1 & 3 & 30.19 \\
\hline Solyc02g076720.2.1 & 30 & 1 & 1 & 1 & 1 & 0.9 & 30.15 \\
\hline Solyc01g010540.2.1 & 30 & 1 & 1 & 1 & 1 & 4.6 & 30.1 \\
\hline Solyc01g101240.2.1 & 30 & 1 & 1 & 1 & 1 & 2.8 & 29.92 \\
\hline Solyc01g008530.2.1 & 30 & 1 & 1 & 1 & 1 & 4.3 & 29.71 \\
\hline Solyc02g068300.2.1 & 30 & 1 & 1 & 1 & 1 & 1.7 & 29.56 \\
\hline Solyc04g007030.2.1 & 30 & 1 & 1 & 1 & 1 & 1.1 & 29.53 \\
\hline Solyc09g089880.2.1 & 29 & 1 & 1 & 1 & 1 & 5.6 & 29.28 \\
\hline Solyc11g068400.1.1 & 29 & 1 & 1 & 1 & 1 & 15.3 & 29.12 \\
\hline Solyc05g056160.2.1 & 29 & 1 & 1 & 1 & 1 & 4.8 & 29.06 \\
\hline Solyc10g006560.2.1 & 27 & 1 & 1 & 1 & 1 & 17.4 & 27.3 \\
\hline Solyc09g007350.2.1 & 27 & 1 & 1 & 1 & 1 & 7.7 & 26.99 \\
\hline Solyc12g056230.1.1 & 27 & 3 & 1 & 2 & 1 & 11.8 & 26.84 \\
\hline Solyc02g093830.2.1 & 26 & 1 & 1 & 1 & 1 & 2 & 26.13 \\
\hline Solyc05g049950.2.1 & 24 & 2 & 1 & 2 & 1 & 7.5 & 10.28 \\
\hline Solyc05g049950.2.1 & 24 & 2 & 1 & 2 & 1 & 7.5 & 24.2 \\
\hline Solyc04g007760.2.1 & 22 & 2 & 1 & 2 & 1 & 21.2 & 29.32 \\
\hline Solyc04g007760.2.1 & 22 & 2 & 1 & 2 & 1 & 21.2 & 22.42 \\
\hline Solyc01g108660.2.1 & 22 & 1 & 1 & 1 & 1 & 3 & 21.82 \\
\hline Solyc04g009590.2.1 & 21 & 1 & 1 & 1 & 1 & 11.8 & 20.66 \\
\hline Solyc03g113800.2.1 & 20 & 2 & 1 & 2 & 1 & 6.5 & 29.03 \\
\hline Solyc12g099660.1.1 & 16 & 1 & 1 & 1 & 1 & 2.8 & 16.39 \\
\hline
\end{tabular}

${ }^{\mathrm{z}}$ Information used for the identification of proteins in iTRAQ analysis of tomato root proteomes.

yProtein accession number in the ITAG Protein database (Release 2.3 on 26 Apr. 2011; Sol Genomics Network, Boyce Thompson Institute, Ithaca, NY).

${ }^{\mathrm{x}}$ Sum of the individual ion scores.

wTotal number of peptide-spectral matches to a particular protein below the e-value cutoff.

${ }^{v}$ Total number of unique peptide spectral matches to a particular protein below the e-value cutoff.

uTotal number of peptide spectral matches to a particular protein with a protein score above the identity threshold.

'Total number of unique peptide-spectral matches to a particular protein with a protein score above the identity threshold.

sercentage of the total protein sequence represented by the identified peptides.

${ }^{\mathrm{r}}$ Highest highest ion score for each identified proteins. 
Supplemental Table 4. Salt and dehydration responsive proteins in tomato roots. ${ }^{\mathrm{z}}$

Protein name
Ran GTPase binding protein
TPR domain containing protein
Alpha-mannosidase
Fructose-bisphosphate aldolase
Actin-depolymerizing factor 1
Fasciclin-like arabinogalactan protein
Proline-rich cell wall protein
Expansin
Hydroxycinnamoyl-CoA shikimate/quinate
hydroxycinnamoyltransferase
Caffeoyl CoA 3-O-methyltransferase
Xylanase inhibitor

Sucrase

Sucrose synthase

Phosphoglucomutase

UTP-glucose 1 phosphate uridylyltransferase

Transketolase 1

6-phosphogluconate dehydrogenase ${ }^{\mathrm{q}}$

Enolase

Pyruvate kinase

Phosphoglycerate kinase

Glyceraldehyde 3-phosphate dehydrogenase ${ }^{\mathrm{q}}$

Malate dehydrogenase ${ }^{q}$

Malic enzyme

Dihydrolipoyl dehydrogenase

Succinyl-CoA ligase $^{q}$

Citrate synthase

Alcohol dehydrogenase $2^{\mathrm{q}}$

Alcohol dehydrogenase zinc-containing

Chitinase

Endochitinase $^{\mathrm{q}}$

Beta-hexosaminidase $b$

Mitochondrial ADP/ATP carrier proteins

Mitochondrial ATP synthase ${ }^{q}$

ATP synthase ${ }^{\mathrm{q}}$

ATP synthase subunit alpha

H-ATPase

V-type proton ATPase subunit $\mathrm{a}^{\mathrm{q}}$

Adenosine kinase

Alanine aminotransferase
N-acetyl-gamma-glutamyl-phosphate reductase
Asparagine synthetase
Aspartate aminotransferase
3-isopropylmalate dehydratase large subunit
Amidase hydantoinase/carbamoylase
3-deoxy-7-phosphoheptulonate synthase
Phosphoserine aminotransferase
Formate dehydrogenase
L-threonine 3-dehydrogenase
5-methyltetrahydropteroyltriglutamate-homocysteine
methyltransferase
Adenosylhomocysteinase
O-methyltransferase

Alanine aminotransferase

$\mathrm{N}$-acetyl-gan

Asparagine synthetase

Aspartate aminotransferase

3-isopropylmalate dehydratase large subunit

Amidase hydantoinase/carbamoylase

ate synthas

Phosphoserine aminotransferase

L-threonine 3-dehydrogenase

5-methyltetrahydropteroyltriglutamate-homocysteine

Adenosylhomocysteinase ${ }^{\mathrm{q}}$

O-methyltransferase ${ }^{q}$

Tomato protein

accession $^{\mathrm{x}}$

LA4 $433^{y}$

LA3465

LA2747

LA1958//LA3465

Root system development and structural integrity

Solyc08g062660.2.1

Solyc02g090090.2.1

Solyc06g068860.2.1

Solyc05g008600.2.1

Solyc09g010440.2.1

Solyc07g053540.1.1

Solyc03g007520.2.1

Solyc08g077910.2.1

Solyc03g117600.2.1

Solyc01g107910.2.1

Solyc01g080010.2.1

Carbohydrate metabolism

Solyc02g067840.2.1 $\quad 1.5^{\mathrm{t}}$

Solyc07g042550.2.1 $\quad 1.4^{\mathrm{t}}$

Solyc04g045340.2.1

Solyc11g011960.1.1

Solyc05g050970.2.1

Solyc04g005160.1.1

Solyc10g085550.1.1

Solyc04g008740.2.1

Solyc07g066600.2.1

Solyc05g014470.2.1

Solyc07g062650.2.1

Solyc05g050120.2.1

Solyc05g053300.2.1

Solyc06g083790.2.1

Solyc01g073740.2.1

Solyc06g059740.2.1

Solyc09g059040.2.1

Solyc10g055820.1.1

Solyc $10 \mathrm{~g} 055810.1 .1$

Solyc05g054710.2.1

ATP regeneration and transmembrane ion transport

Solyc11g062130.1.1 $\quad 1.5^{\mathrm{t}} \quad 1.8^{\mathrm{t}}$

Solyc00g009020.2.1 $\quad 1.3^{\mathrm{t}} \quad 1.1$

Solyc12g55800.1.1

Solyc11g039980.1.1

Solyc06g071100.2.1

Solyc01g110120.2.1

Solyc10g086190.1.1

Amino acid metabolism

Solyc03g123610.2.1

Solyc01g108660.2.1

Solyc01g079880.2.1

Solyc07g055210.2.1

Solyc07g052350.2.1

Solyc09g083410.2.1

Solyc04g074480.2.1

Solyc02g082830.1.1

Solyc02g086880.2.1

Solyc01g006510.2.1

Solyc10g081510.1.1

Solyc09g092380.2.1

Solyc03g080180.2.1 $1.7^{\mathrm{t}}$

1.2

$1.4^{\mathrm{t}}$

$1.4^{\mathrm{t}}$

$1.7^{\mathrm{t}}$

$1.4^{\mathrm{t}}$

NI

1.2

1.4

$1.8^{\mathrm{t}}$

$1.7^{\mathrm{t}}$

$.5^{\mathrm{t}}$

$1.6^{\mathrm{t}}$
$1.5^{\mathrm{t}}$

1.3

1.3

1.2

1.3

$1.4^{\mathrm{t}}$

$1.3^{\mathrm{t}}$

$1.4^{\mathrm{t}}$

1.1

$1.3^{\mathrm{t}}$

1.2

1.2

$2.1^{\mathrm{t}}$

$2.0^{\mathrm{t}}$

$1.3^{\mathrm{t}}$

1.3

$1.3^{\mathrm{t}}$

1.1

1.3

1.1

1.3

1.5

1.2

$1.8^{\mathrm{t}}$

$1.3^{\mathrm{t}}$

1.4

1.3

$1.4^{\mathrm{t}}$

1.4

$2.0^{\mathrm{t}}$

$1.4^{\mathrm{t}}$

$1.4^{\mathrm{t}}$

$1.3^{\mathrm{t}}$

$2.2^{\mathrm{t}}$

1.1
$1.3^{\mathrm{t}}$
$1.3^{\mathrm{t}}$
1.1
1.0
1.2
$1.3^{\mathrm{t}}$
$1.8^{\mathrm{t}}$
$1.8^{\mathrm{t}}$

1.1

$1.7^{\mathrm{t}}$

1.4

$2.2^{\mathrm{t}}$

$1.6^{\mathrm{t}}$

$1.6^{\mathrm{t}}$

$1.6^{\mathrm{t}}$

$1.5^{\mathrm{t}}$

$1.4^{\mathrm{t}}$

$1.5^{\mathrm{t}}$

$1.3^{\mathrm{t}}$

$1.4^{\mathrm{t}}$

$1.4^{\mathrm{t}}$

$1.7^{\mathrm{t}}$

1.2

$1.5^{\mathrm{t}}$

$1.7^{\mathrm{t}}$

$2.6^{\mathrm{t}}$

$1.9^{\mathrm{t}}$

1.2

$1.4^{\mathrm{t}}$

$2.9^{t}$

$1.8^{\mathrm{t}}$

$1.5^{\mathrm{t}}$

$1.5^{\mathrm{t}}$

$1.7^{\mathrm{t}}$

$1.5^{\mathrm{t}}$

$1.6^{\mathrm{t}}$

$1.5^{\mathrm{t}}$

$1.4^{\mathrm{t}}$

$1.9^{\mathrm{t}}$

$1.6^{\mathrm{t}}$

$1.6^{\mathrm{t}}$

$2.5^{\mathrm{t}}$

$1.7^{\mathrm{t}}$

$1.6^{\mathrm{t}}$

$1.5^{\mathrm{t}}$

NI

$2.1^{\mathrm{t}}$

$1.5^{\mathrm{t}}$
1.7
$\mathrm{NI}^{\mathrm{s}}$

NI

NI

NI

NI

NI

NI

NI

NI

NI

NI

NI

NI

dn

NI

NI

NI

up

NI

NI

NI

$\mathrm{dn}$

up

NI

NI

NI

NI

NI

NI

NI

NI

NI

NI

up

NI

NI

NI

NI

NI

NI

NI

NI

NI

NI

NI

NI

NI

NI

up

up

NI

up/ncr

NI

NI

$\mathrm{dn} / \mathrm{dn}$

NI

up/dn

NI

NI

NI

up/nc $\mathrm{dn} / \mathrm{dn}$

NI

dn/up

NI

$\mathrm{dn} / \mathrm{nc}$

NI

$\mathrm{dn} / \mathrm{up}$

$\mathrm{dn} / \mathrm{nc}$

NI

up/nc

$\mathrm{dn} / \mathrm{nc}$

$\mathrm{dn} / \mathrm{dn}$

$\mathrm{dn} / \mathrm{dn}$

$\mathrm{dn} / \mathrm{nc}$

NI

NI

NI

$\mathrm{dn} / \mathrm{nc}$

NI

NI

NI

$\mathrm{dn} / \mathrm{nc}$

NI

NI

NI

NI

up/nc

$\mathrm{dn} / \mathrm{dn}$

$\mathrm{dn} / \mathrm{nc}$

NI

$\mathrm{dn} / \mathrm{nc}$

NI

$\mathrm{dn} / \mathrm{dn}$

NI

dn/up 
Supplemental Table 4. Continued.

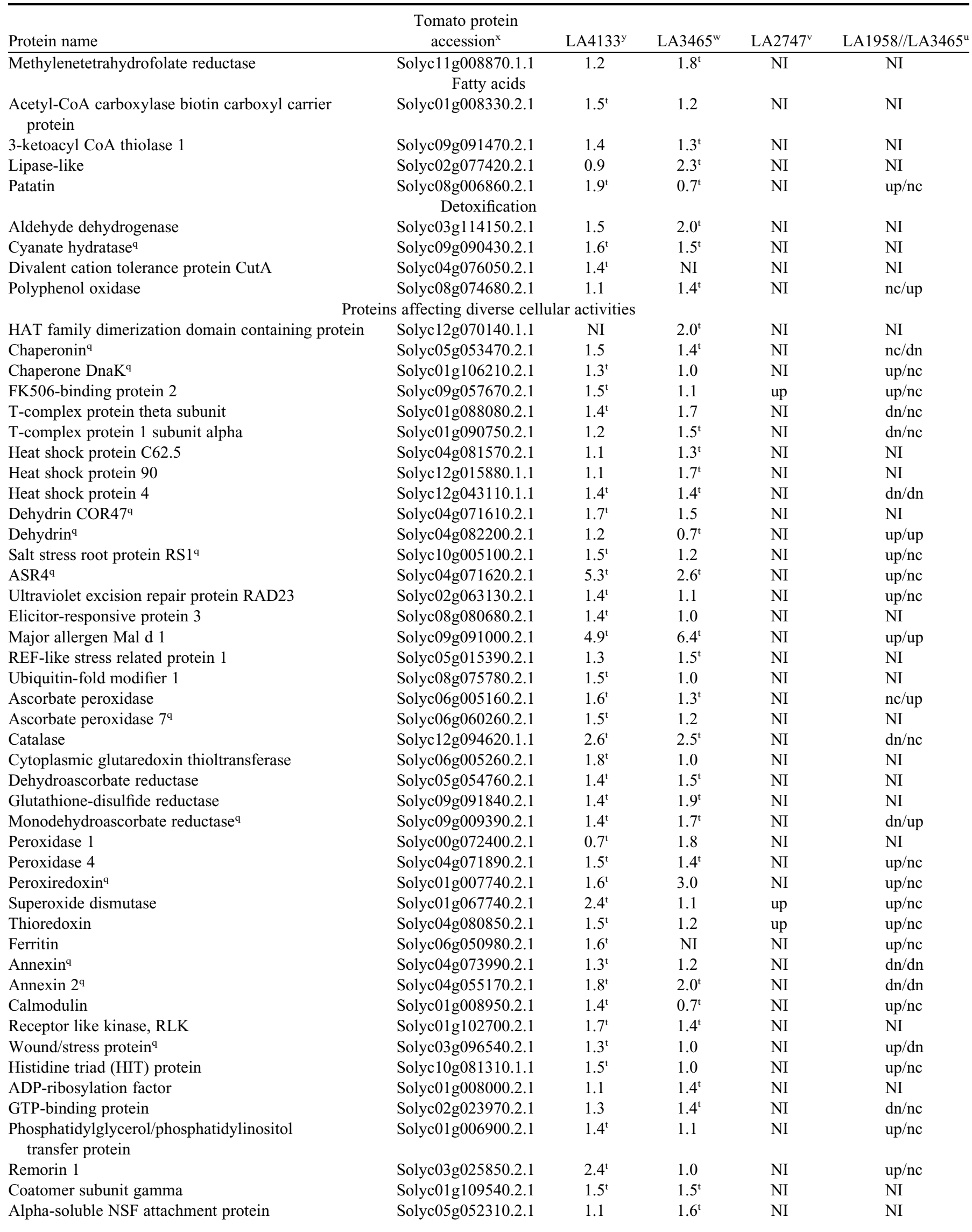


Supplemental Table 4. Continued.

\begin{tabular}{|c|c|c|c|c|c|}
\hline Protein name & $\begin{array}{l}\text { Tomato protein } \\
\text { accession }^{x}\end{array}$ & LA4133 ${ }^{y}$ & LA3465 w & LA $2747^{\mathrm{v}}$ & LA1958//LA3465" \\
\hline Translocon-associated protein subunit beta & Solyc02g094440.2.1 & 1.0 & $1.3^{\mathrm{t}}$ & NI & NI \\
\hline Mitochondrial import receptor subunit TOM20 & Solyc02g068130.2.1 & $1.5^{\mathrm{t}}$ & 1.0 & NI & NI \\
\hline \multicolumn{6}{|c|}{ Protein turnover and post-translational modification } \\
\hline Mitochondrial processing peptidase alpha subunit & Solyc12g008630.1.1 & $1.3^{\mathrm{t}}$ & 1.1 & $\mathrm{NI}$ & $\mathrm{dn} / \mathrm{nc}$ \\
\hline Cathepsin B-like cysteine proteinase & Solyc12g088670.1.1 & $1.3^{\mathrm{t}}$ & 1.1 & NI & $\mathrm{dn} / \mathrm{nc}$ \\
\hline Protease Do-like (S2 serine-type protease) & Solyc02g086830.2.1 & $1.5^{\mathrm{t}}$ & 0.9 & NI & NI \\
\hline Chymotrypsin inhibitor- 2 & Solyc08g080630.2.1 & $1.4^{\mathrm{t}}$ & 1.0 & NI & $\mathrm{up} / \mathrm{nc}$ \\
\hline Leucyl aminopeptidase & Solyc12g010040.1.1 & $1.4^{\mathrm{t}}$ & $1.5^{\mathrm{t}}$ & NI & $\mathrm{dn} / \mathrm{nc}$ \\
\hline \multicolumn{6}{|c|}{ DNA replication and gene expression } \\
\hline MFP1 attachment factor 1 & Solyc04g078380.1.1 & $2.0^{\mathrm{t}}$ & NI & $\mathrm{NI}$ & $\mathrm{NI}$ \\
\hline Single-stranded DNA binding protein & Solyc10g086150.1.1 & $2.0^{\mathrm{t}}$ & 1.0 & NI & NI \\
\hline Basic leucine zipper and W2 domain protein & Solyc05g055770.2.1 & $1.8^{\mathrm{t}}$ & NI & NI & NI/up \\
\hline Glycine-rich RNA-binding protein & Solyc01g109660.2.1 & $1.5^{\mathrm{t}}$ & 0.8 & NI & NI \\
\hline Tudor/nuclease domain-containing protein & Solyc03g118020.2.1 & 1.2 & $1.5^{\mathrm{t}}$ & NI & NI \\
\hline Glycine rich protein-RNA binding protein & Solyc05g053780.2.1 & 1.4 & $0.7^{\mathrm{t}}$ & NI & NI \\
\hline Translation elongation EFTu/EF1A & Solyc06g069020.2.1 & $1.7^{\mathrm{t}}$ & $1.9^{\mathrm{t}}$ & NI & NI \\
\hline EF1B & Solyc07g016150.2.1 & $1.3^{\mathrm{t}}$ & 0.8 & NI & NI \\
\hline Elongation factor $\mathrm{Tu}$ & Solyc09g073000.2.1 & $1.3^{\mathrm{t}}$ & 1.0 & $\mathrm{NI}$ & $\mathrm{NI}$ \\
\hline Elongation factor EF-2 & Solyc08g062920.2.1 & $1.3^{\mathrm{t}}$ & $1.4^{\mathrm{t}}$ & NI & $\mathrm{dn} / \mathrm{dn}$ \\
\hline $\begin{array}{l}\text { Insulin-like growth factor } 2 \text { mRNA-binding } \\
\text { protein } 2\end{array}$ & Solyc12g095960.1.1 & $1.4^{\mathrm{t}}$ & 1.0 & NI & NI \\
\hline $30 \mathrm{~S}$ ribosomal protein $\mathrm{S} 5$ & Solyc04g063290.2.1 & $1.3^{\mathrm{t}}$ & 1.1 & NI & $\mathrm{dn} / \mathrm{dn}$ \\
\hline 30S ribosomal protein S19 & Solyc02g082000.2.1 & 1.0 & $0.6^{\mathrm{t}}$ & NI & $\mathrm{dn} / \mathrm{dn}$ \\
\hline 60 S ribosomal protein $\mathrm{L} 22-2$ & Solyc01g099830.2.1 & 0.7 & $0.6^{\mathrm{t}}$ & NI & NI \\
\hline 60 S ribosomal protein L35 & Solyc04g010240.2.1 & 0.8 & $0.5^{\mathrm{t}}$ & NI & $\mathrm{up} / \mathrm{dn}$ \\
\hline 60 S ribosomal protein L6 & Solyc11g012110.1.1 & 0.6 & $0.6^{\mathrm{t}}$ & NI & $\mathrm{dn} / \mathrm{nc}$ \\
\hline 40S ribosomal protein S13 & Solyc01g091220.2.1 & 0.8 & $0.4^{\mathrm{t}}$ & NI & NI \\
\hline $40 \mathrm{~S}$ ribosomal protein $\mathrm{S} 24$ & Solyc01g097870.2.1 & $0.7^{\mathrm{t}}$ & 0.7 & NI & $\mathrm{NI}$ \\
\hline $40 \mathrm{~S}$ ribosomal protein $\mathrm{S} 7$ & Solyc06g069090.2.1 & 1.0 & $0.7^{\mathrm{t}}$ & $\mathrm{NI}$ & NI \\
\hline
\end{tabular}

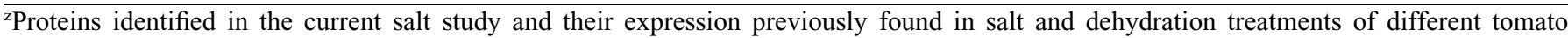
accessions.

yProtein accession number in the ITAG Protein database (Release 2.3 on 26 Apr. 2011; Sol Genomics Network, Boyce Thompson Institute, Ithaca, NY).

${ }^{\mathrm{x}}$ Fold (treated/control) change in salt treatment of tolerant cherry tomato (Solanum lycopersicum var. cerasiforme) LA4133 in the current study.

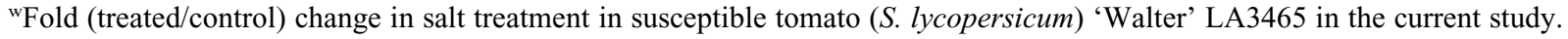

"Salt treatment of Solanum chilense (Zhou et al., 2011).

"Dehydration treatment of tolerant $S$. chilense LA1958 and susceptible 'Walter' LA3465 (Zhou et al., 2013).

tProtein with significant changes from salt-treated to untreated groups.

${ }^{\mathrm{s}} \mathrm{NI}=$ not identified in the respective tomato accession.

rProtein changes from treated group to non-treated group: up = induced, $\mathrm{dn}=$ repressed, $\mathrm{nc}=$ no change.

${ }^{\mathrm{q}}$ Salt-response protein in Arabidopsis thaliana annotated in String Database (Franceschini et al., 2013). 